\title{
PROSPECÇÃO DE OPORTUNIDADES PARA A OTIMIZAÇÃO DOS PROCESSOS DE USINAGEM NA PEQUENA E MÉDIA EMPRESA EM SÃO CARLOS / SP
}

Tobias Heymeyer

Dissertação apresentada à Escola de
Engenharia de São Carlos, da
Universidade de São Paulo, como parte
dos requisitos para a obtenção do título
de Mestre em Engenharia de Produção.

ORIENTADOR: Prof. Dr. João Fernando Gomes de Oliveira 
Ficha catalográfica preparada pela Seção de Tratamento da Informação do Serviço de Biblioteca - EESC/USP

H618p Prospecção de oportunidades para a otimização dos processos de usinagem na pequena e média empresa em São Carlos/SP / Tobias Heymeyer. -- São Carlos, 2006.

Dissertação (Mestrado) - - Escola de Engenharia de São Carlos-Universidade de São Paulo, 2006.

Área: Engenharia de Produção.

Orientador: Prof. Dr. João Fernando Gomes de oliveira.

1. Usinagem. 2. Tecnologia. 3. Desenvolvimento sustentável. 4. Pequena e Média Empresa (PME). 5. Processos de fabricação. I. Titulo. 


\section{FOLHA DE JULGAMENTO}

Candidato: Engenheiro TOBIAS HEYMEYER

Dissertação defendida e jullgada em 12-04-2006 perante a Comissão Julgadora:

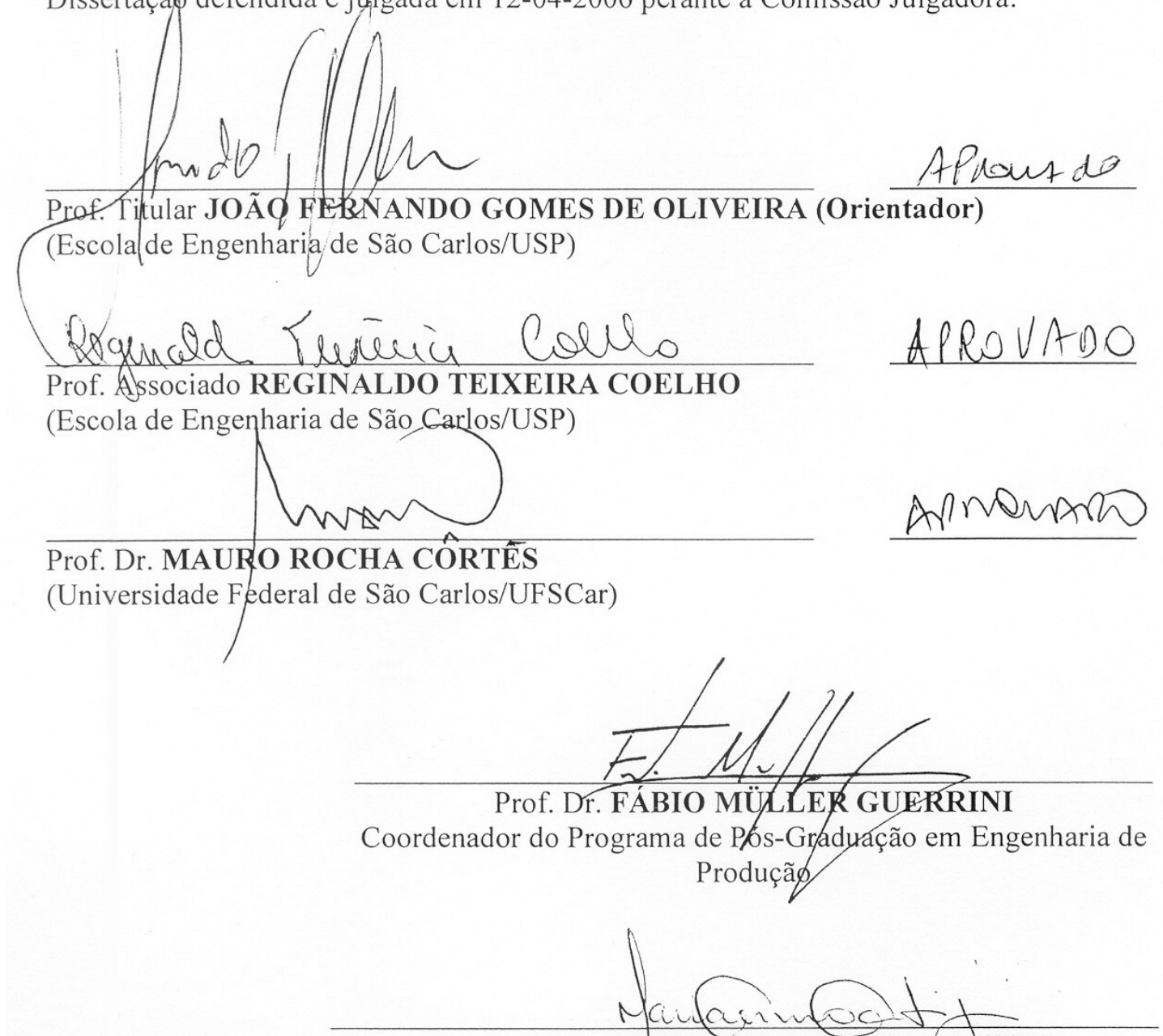

Profa. Titular MARIA DO CARMO CALJJURI

Presidente da Comissão de Pós-Graduação 
Dedicamos este trabalho à "VIDA"

(presente até no fluido de corte) 


\section{AGRADECIMENTOS}

Expresso aqui a honra de ter o professor João Fernando Gomes de Oliveira como orientador e a gratidão pela formação resultante deste processo.

Agradecemos a CAPES pelo suporte na forma de uma bolsa de estudos, ao programa de pós-graduação do Departamento de Engenharia de Produção e em especial aos professores Edmundo Escrivão Filho e Reginaldo Teixeira Coelho.

Relacionamos abaixo todos cuja colaboração e empenho viabilizaram este trabalho merecendo nosso reconhecimento.

Equipe do Laboratório para a Otimização dos Processos de Fabricação (OPF) pelo envolvimento com a proposta e a disposição em interagir para o sucesso do trabalho:

Alessandro Roger Rodrigues, Lincoln Cardoso Brandão, Marcelo Batista Ferreira.

Ao suporte acadêmico

Carlos Magno de Oliveira Valente, Fábio Ferraz Júnior.

Grupo de Adequação Ambiental em Manufatura

Aldo Ometto, Alexandre Fernandes Ono, Américo Guelere Filho, Salete Martins Alves.

Imagens e ilustrações

Lincoln Cardoso Brandão, Magno Botelho Castelo Branco.

Normalização técnica

Elena Luzia Palloni Gonçalves.

Revisão do trabalho

Federico Martinez Aneiro, Thiago Valle França.

Suporte técnico de informática

Daniel Picon, Fernando Walker Lima da Silva.

Suporte técnico no laboratório

Adolfo Ferrarin, Ariel Fernando Gatti.

Laboratório de Resíduos Químicos USP - São Carlos

Elias Paulo Tessaro, Flávio Antônio Cortez, Leny Borghesan A. Alberguini.

As empresas

Cofecort Ferramentas

Mário Sergio Toyama, Nicolau Nebel.

Eduma

Cristiano Lopes de Oliveira, Eduardo Mascarin Jr., Fernanda D'agostino, Idevaldo Z. Santos, Marcos D. Gallo. 
Microquímica

Carlos Augusto Branco, Carlos Sartori, Jairo K. Mizuouchi, Paschoal Cassani.

Sandvik Coromant

Aldeci Vieira Santos, Carlos Ancelmo de Oliveira Junior.

As empresas não identificadas que colaboraram com este estudo.

Secretarias

Irene Migliato Libardi, José Luis Chiaretto.

Instituto Fábrica do Milenio

Cristiano Antonio Garcia e Francis Ribeiro da Silva.

Colegas do Laboratório OPF que proporcionaram um excelente ambiente de trabalho Adriano Fagali de Souza, Aldo Braghini Junior, Arthur Braga, Carlos Elias da Silva Junior, Elias Arbex, Emanuel Nunes Borges, Eraldo Janonne da Silva, Flávio Camarinho Moreira, Henrique Guimarães Destro, Hugo Martinelli Watanuki, Jen Po Wang, Luciano Schuhli, Luis Carlos R. Morenghi, Marcelo Del Guerra, Ricardo Arai, Sérgio Tókio Tanikawa.

Compartilhar uma residência vivendo o novo paradigma

Bruno Franceschi, Jean Marc Bolonha Volland.

Disposição em discutir e oferecer sugestões

Débora Morato Pinto, José Ricardo M. Fortunato, Lucia e Gabriel Feltran, Sérgio Perussi Filho.

Suporte e apoio incondicional por toda a vida acadêmica

Família Heymeyer

A todos que de alguma forma contribuíram no desenvolvimento deste trabalho. 


\section{RESUMO}

HEYMEYER, T. (2006). Prospecção de oportunidades para a otimização dos processos de usinagem na pequena e média empresa em São Carlos / SP. 112p. Dissertação (Mestrado) - Escola de Engenharia de São Carlos, Universidade de São Paulo, São Carlos.

As operações de usinagem viabilizam a construção de máquinas e equipamentos que proporcionam a manutenção do bem estar da sociedade e a sua evolução. Com o estudo das tecnologias e a adequação dos sistemas de produção ao paradigma “desenvolvimento sustentável”, é possível discutir as operações de corte com ferramentas de geometria definida e oferecer suporte ao desenvolvimento destes processos nas pequenas e médias empresas (PME). Estas unidades do sistema produtivo estão sujeitas ao rigor do mercado e suas transformações, devendo ter condições de oferecer respostas à altura de sua função. $\mathrm{O}$ acesso ao conhecimento e à tecnologia leva ao fortalecimento da empresa através dos ganhos de competência e competitividade. A tecnologia proporciona condições de maior produtividade, qualidade e controle dos processos e o novo paradigma de produção conduz à eliminação dos impactos ambientais, racionalização e redução do consumo de recursos não renováveis, para a preservação e manutenção do planeta e seus sistemas naturais. No trabalho desenvolvido na presente pesquisa foi possível conhecer e avaliar as instalações e corpo técnico de onze empresas (PME), com processos de usinagem, no município de São Carlos, São Paulo. A organização dos dados permite a construção de um cenário onde são evidenciados potenciais e carências. Na etapa seguinte foi eleito um processo, em uma das empresas, que recebeu intervenções para melhor desempenho nos aspectos econômico, social e ambiental. Os resultados alcançados permitem que se faça projeções de ganhos para todo o parque industrial estudado. O mecanismo de apoio às pequenas e médias empresas em uma avaliação final sugere um salto de qualidade, referendando o modelo que pode ser facilmente reproduzido.

Palavras-chave: Usinagem. Tecnologia. Desenvolvimento sustentável. Pequena e média empresa (PME). Processos de fabricação. 


\section{ABSTRACT}

HEYMEYER, T. (2006). Prospection of opportunities for the optimization of machining processes at small and médium-sized enterprises in São Carlos / SP. 112p. Dissertação (Mestrado) - Escola de Engenharia de São Carlos, Universidade de São Paulo, São Carlos.

Machining operations make possible the construction of machines and equipment which provide the maintenance of society welfare and its evolution. Studying the technology directions and the production systems adequacy to the "sustainable development" paradigm enables the discussion of machining and the fostering of the processes at the small and medium-sized enterprises (SME). Because of the vulnerability to the market and its transformations these companies should have conditions to respond to the demands at the importance level of their function. The access to the knowledge and technology brings a gain in competence and competitiveness. Technology provides conditions for higher productivity, quality and processes control, as well as the new production paradigm leads to the elimination of the environmental impacts, rationalization and reduction in the use of non renewable materials preserving and maintaining the planet's natural systems. In this research it was possible to know the facilities and the technical staff of eleven metalworking companies (SME), in São Carlos City, São Paulo State. The gathered data allows to draw a portrait that puts in evidence the potentials and deficiencies. On a next stage a specific machining operation was chosen to be improved in the economic, social and environmental aspects. The achieved results allow projections of gains in the industrial park. In a final evaluation of the small and medium-sized enterprises support mechanism it suggests a quality improvement assuring the availability of the model that is easily reproducible.

Keywords: Machining. Technology. Sustainable development. Small and medium-sized enterprises (SME). Manufacturing processes. 


\section{RESUMO}

\section{ABSTRACT}

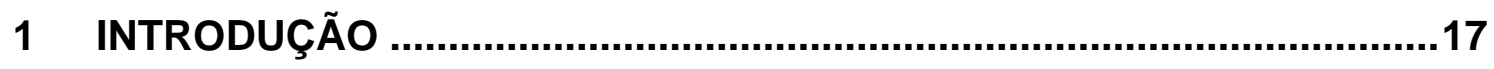

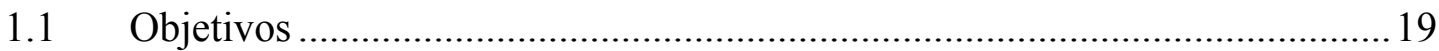

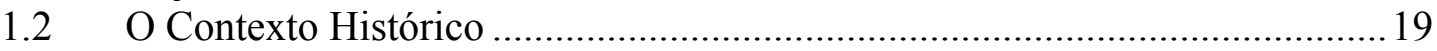

1.2.1 O Conceito Desenvolvimento Sustentável.........................................23

1.2.2 Ecologia Industrial e Desmaterialização..............................................24

1.3 Considerações Relevantes ................................................................... 28

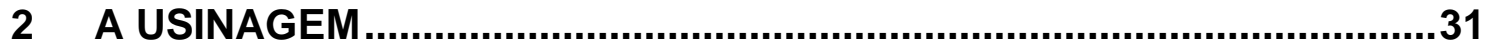

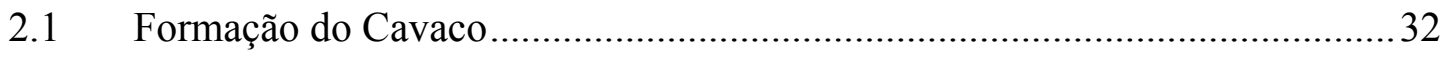

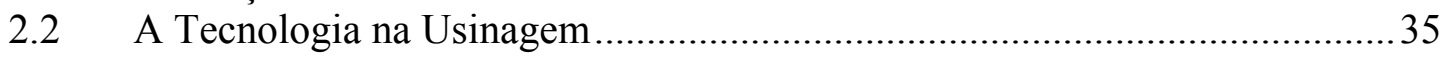

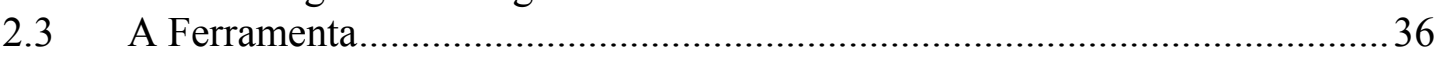

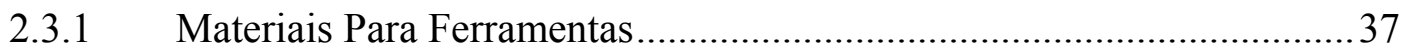

2.3.2 Manufatura da Ferramenta de Corte ...................................................... 38

2.3.3 Geometria da Ferramenta de Corte ..................................................... 40

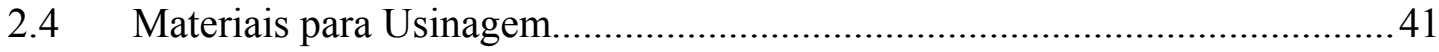

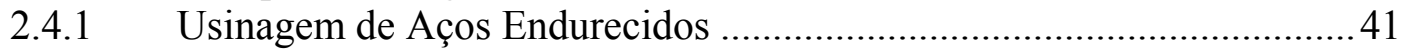

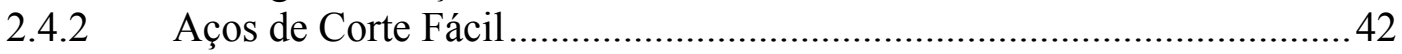

2.4.3 Usinagem de Materiais Fundidos............................................................ 43

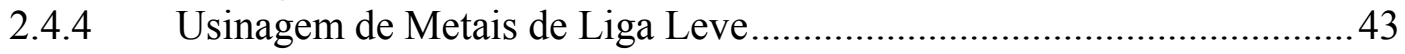

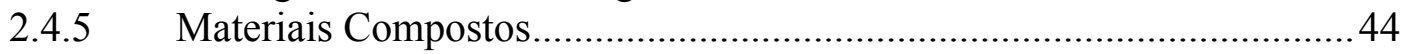

2.4.6 Usinagem de Materiais Aeroespaciais ................................................. 44

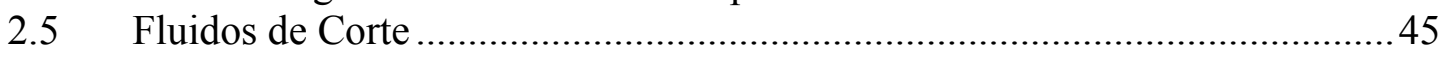

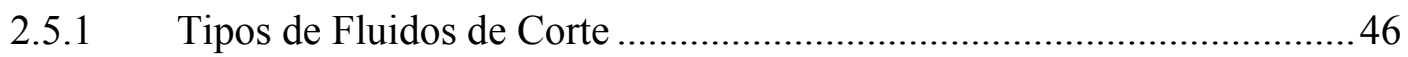

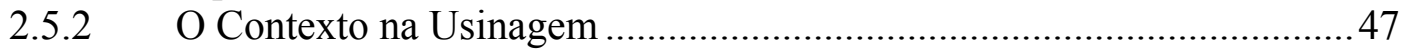

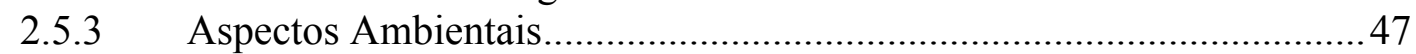

2.5.4 Alternativas ao Emprego dos Fluidos de Corte.......................................49

2.6 Desenvolvimento do Processo de Corte e da Máquina Ferramenta.................50

2.6.1 Processo Integrado e "Usinagem Completa" ...........................................50

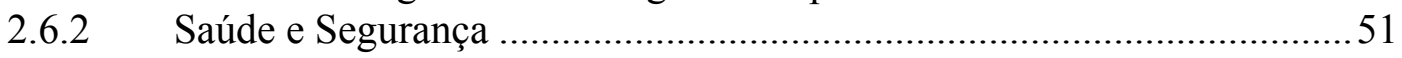

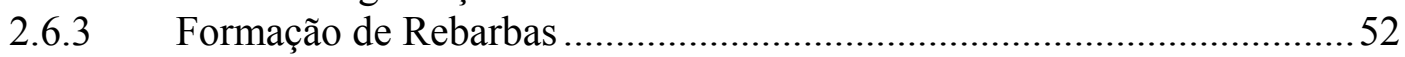

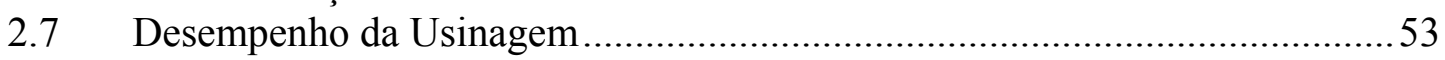

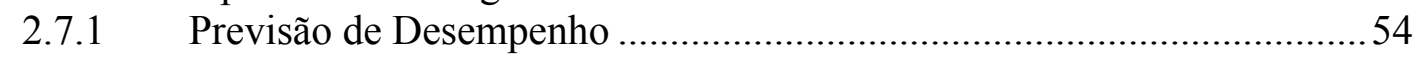

2.7.2 Simulação Baseada na Dinâmica Molecular............................................55

2.7.3 Novas Direções no Incremento da Compreensão do Processo .................55

2.7.4 Monitoramento das Operações de Corte ................................................56

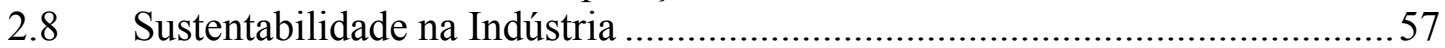

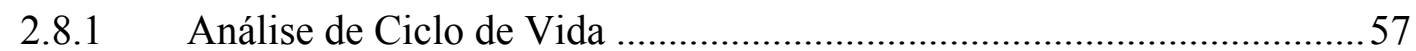

2.8.2 Normas, Certificações e Produção Mais Limpa........................................58

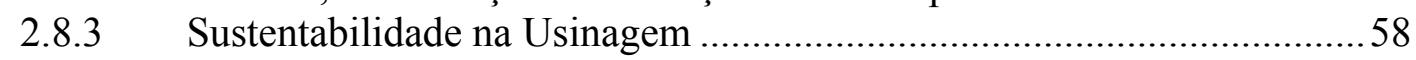

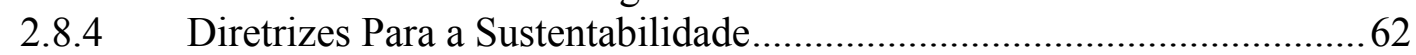


3 MATERIAIS E MÉTODOS...............................................................65

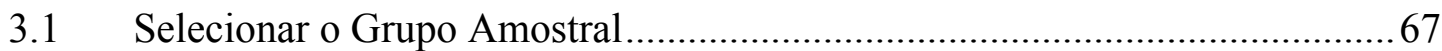

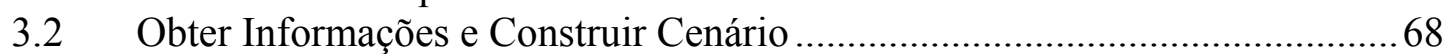

3.3 Verificar Oportunidades de Intervenções em Ações Pontuais.........................68

3.4 Eleger o Processo que Receberá as Intervenções...............................................69

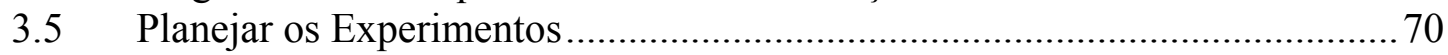

3.5.1 Tecnologia de Usinagem e Otimização do Processo. ............................... 71

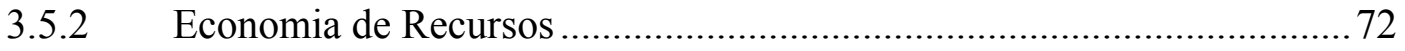

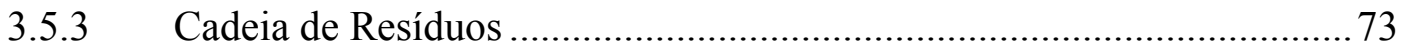

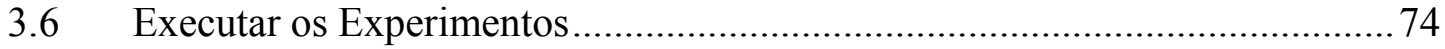

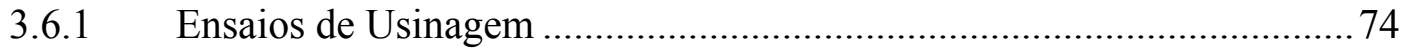

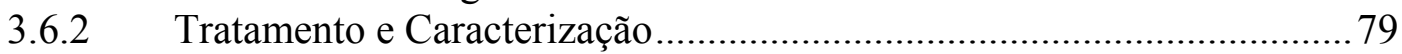

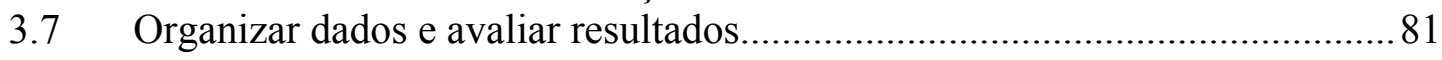

4 DISCUSSÃO E RESULTADOS .......................................................... 83

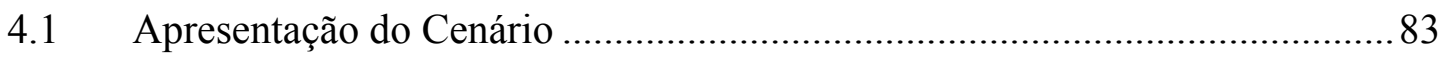

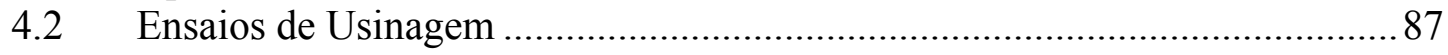

4.2.1 Tecnologia de Usinagem e Otimização do Processo .............................. 87

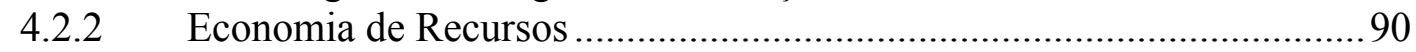

4.2.3 Considerações Complementares ............................................................93

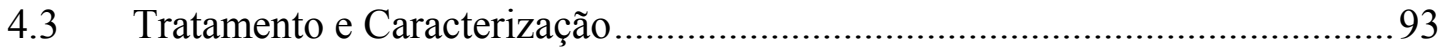

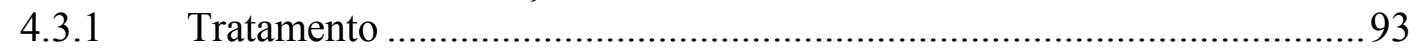

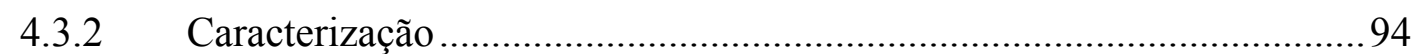

4.4 Discussão dos Ganhos e Repercussão na Empresa ........................................97

4.4.1 Ensaios de Usinagem ..................................................................... 97

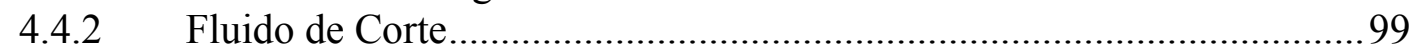

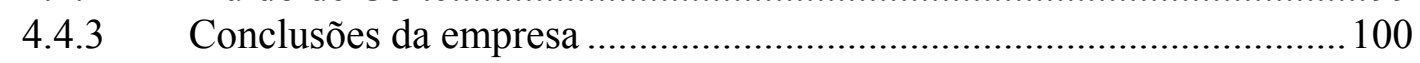

4.5 Projeção de Possibilidades no Parque Industrial........................................... 100

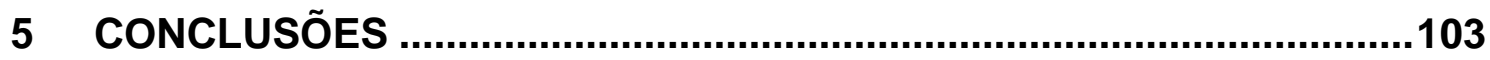

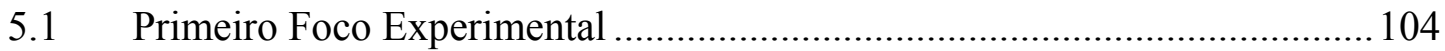

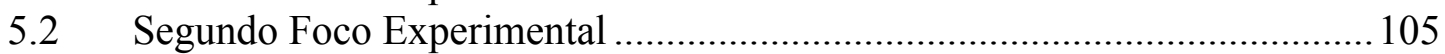

5.3 Terceiro Foco Experimental...................................................................... 105

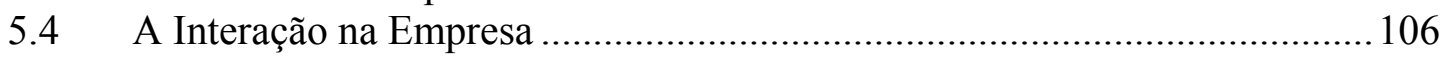

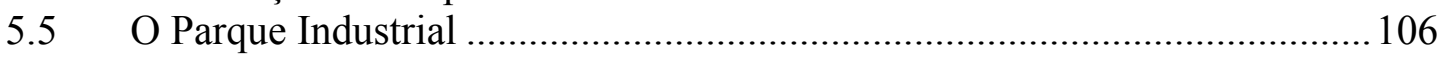

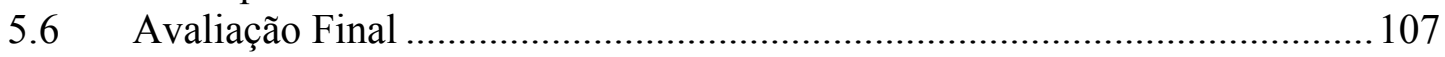

5.7 Sugestões Para Trabalhos Futuros ............................................................. 107

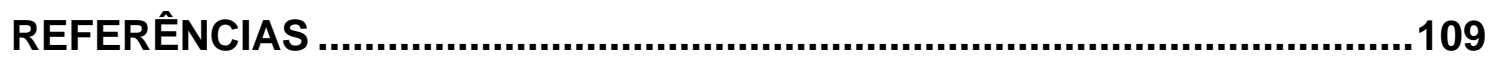

APÊNDICE A - Questionários...........................................................115

APÊNDICE B - Ensaios de Usinagem .................................................119

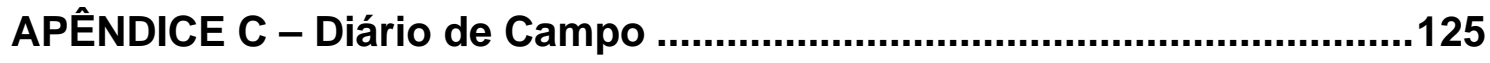

APÊNDICE D - Desempenho Das Ferramentas ........................................129

APÊNDICE E - Custos do Processo ……............................................133

APÊNDICE F - Estimativas de Economia ................................................135 


\section{INTRODUÇÃO}

No espectro de competências do Núcleo de Manufatura Avançada (NUMA), o Laboratório para a Otimização dos Processos de Fabricação (OPF) adota como tema de estudos as tecnologias aplicadas aos processos de usinagem. A discussão das condições futuras para as operações de corte deve considerar o novo desafio para a indústria: a mudança de paradigmas para o "desenvolvimento sustentável”. Determinado por Kuhn (1996), como um contexto, onde valores comuns organizam o comportamento de indivíduos, formal ou subjetivamente, o novo paradigma conduz a uma reavaliação das relações da sociedade industrial com o planeta terra.

O conhecimento organizado deve viabilizar a proposta de captar as necessidades e carências tecnológicas das empresas para disseminar o conhecimento, transferir tecnologia e desta forma criar condições para o desenvolvimento de um modelo de interação que, reproduzido, conduz ao melhor desempenho da indústria.

O início deste trabalho é a determinação da base conceitual, com as definições da nova abordagem aos processos industriais e o contexto histórico em que está inserida. Os experimentos são dirigidos para as operações de corte com ferramentas de geometria definida, que recebem estudo das tendências, aspectos que devem ser aprimorados e soluções consagradas para estes processos. O conhecimento organizado é implementado para um processo de uma empresa de pequeno porte com a proposta de sua difusão, oferecendo suporte a esta classe de indústria que deve manter-se competitiva e alinhada ao desenvolvimento tecnológico.

As carências e vulnerabilidade de empresas deste porte são de senso comum, mas ao avaliar os dados da literatura, são verificados os fatores que tornam fundamental a interação. 
Segundo SERVIÇO BRASILEIRO DE APOIO ÀS MICRO E PEQUENAS EMPRESAS - SEBRAE (2005a) as pequenas e médias empresas (PME), em conjunto, são 99,2 \% do número de empresas formais e geram 57,2\% dos empregos no Brasil.

Em todo mundo mais de $90 \%$ das empresas pertencem a esta classe (UNITED NATIONS ENVIRONMENT PROGRAM - UNEP, 2003; WORLD COMMISSION FOR ENVIRONMENT AND DEVELOPMENT - WCED, 1987).

Estima-se que as PME podem contribuir com até $70 \%$ da poluição industrial (HILLARY, 2004; UNEP, 2003; WCED, 1987). Os impactos ambientais a elas relacionados crescem assim como a sua importância econômica (UNEP, 2003).

Ao levar o conhecimento e implementar tecnologias acessíveis ao pequeno empreendedor é possível adequar a produção às condições determinadas pelo tripé, no qual a eficiência econômica é equilibrada pela responsabilidade social e a preservação dos recursos não renováveis, assim como dos sistemas naturais.

Os aspectos sociais e ambientais são de grande importância e não podem ser negligenciados, mas é no desenvolvimento da competência nos processos de usinagem, que são abordados os trabalhos desenvolvidos na empresa. Segundo Rother e Shook (1999) os ganhos de produtividade solidificam a capacidade de agregar valor e de domínio do negócio, sendo também o objetivo do estudo que se apresenta.

DeGarmo (1957) alerta para a importância da fabricação de maneira econômica, o desenvolvimento dos processos e o planejamento da produção, ressaltando a necessidade de entender os fundamentos do corte de metais, suas exigências, vantagens e limitações.

Um processo controlado, com os fenômenos conhecidos, deve ser tratado como um sistema, tendo suas entradas e saídas monitoradas. Na análise para ampliar a eficiência do sistema é possível, com o domínio da técnica, reduzir os impactos ambientais relacionados e obter redução de custos.

Com esta perspectiva tem início a atividade de suporte aos processos de usinagem e seu futuro na pequena e média empresa que deve evoluir inserida no contexto do “desenvolvimento sustentável”. 


\subsection{Objetivos}

Investigar as possibilidades de oferecer suporte aos processos de usinagem na pequena e média empresa (PME), para condições de operação com maior competência e competitividade, considerando as tendências tecnológicas e a mudança de paradigma para o "desenvolvimento sustentável".

Como objetivos parciais apresentam-se a realização de levantamento para conhecer a situação da indústria local e a intervenção em um processo com a proposta de obter melhor desempenho de operação nos aspectos econômico, ambiental e social.

\subsection{O Contexto Histórico}

Iniciada em meados do século XVIII, com o setor têxtil, a produção industrial no planeta e a sua produtividade aumentaram surpreendentemente (GRÜBLER 1994). Passando por diversos estágios, a sociedade industrial incorporou avanços científicos e tecnológicos, proporcionando aos seus indivíduos aumento significativo da expectativa de vida e sua qualidade. No entanto a evolução, ditada pelo modo de produção capitalista, acontece em ritmo acelerado e desordenadamente. Enquanto parte da população planetária vive em condições precárias de subsistência, nações desenvolvidas consomem recursos naturais e, lançam nos sistemas da biosfera, cargas de elementos, que não são absorvidos, gerando os problemas ambientais, hoje senso comum nestas sociedades.

Com o advento da revolução industrial, e a respectiva organização da economia, são estabelecidos padrões de produção e de consumo sem que fosse considerada a capacidade de manutenção da vida e dos sistemas naturais.

A Tabela 1.1 oferece um panorama da evolução industrial para a contextualização do momento histórico em que se encontra a sociedade e seus sistemas. 
Tabela 1.1 - Panorama da Evolução Industrial.

\begin{tabular}{|c|c|c|c|c|c|}
\hline Agrupamento & $\begin{array}{l}\text { 1750-1820 } \\
\text { Têxtil }\end{array}$ & $\begin{array}{l}\text { 1800-1870 } \\
\text { Vapor }\end{array}$ & $\begin{array}{l}\text { 1850-1940 } \\
\text { Engenharia } \\
\text { Pesada }\end{array}$ & $\begin{array}{c}1920-2000 \\
\text { Consumo e } \\
\text { Produção de Massa }\end{array}$ & $\begin{array}{c}\text { 1980- } \\
\text { Qualidade } \\
\text { Total }\end{array}$ \\
\hline \multicolumn{6}{|l|}{ Dominante } \\
\hline Energia & $\begin{array}{l}\text { Água,Vento, } \\
\text { Animal, } \\
\text { Lenha }\end{array}$ & $\begin{array}{l}\text { Lenha, } \\
\text { Animal, } \\
\text { Carvão }\end{array}$ & Carvão & $\begin{array}{l}\text { Petróleo, } \\
\text { Eletricidade }\end{array}$ & Gás, Eletricidade \\
\hline $\begin{array}{c}\text { Transporte e } \\
\text { Comunicação }\end{array}$ & Estradas & Canais & $\begin{array}{l}\text { Ferrovias, } \\
\text { Navegação a } \\
\text { Vapor, } \\
\text { Telégrafo } \\
\end{array}$ & $\begin{array}{c}\text { Estradas, Telefone, } \\
\text { Rádio e TV }\end{array}$ & $\begin{array}{l}\text { Estradas, } \\
\text { Transporte } \\
\text { Aéreo, } \\
\text { Comunicação } \\
\text { Multimídia } \\
\end{array}$ \\
\hline Materiais & Ferro & Ferro Batido & Aço & $\begin{array}{l}\text { Petroquímicos, } \\
\text { Plásticos, Aço, } \\
\text { Alumínio }\end{array}$ & $\begin{array}{c}\text { Ligas, Materiais } \\
\text { Especializados }\end{array}$ \\
\hline Indústria & Fundições & $\begin{array}{c}\text { Vapor } \\
\text { Estacionário, } \\
\text { Mecanização }\end{array}$ & $\begin{array}{l}\text { Maquinário } \\
\text { Pesado, } \\
\text { Químicos, } \\
\text { Materiais } \\
\text { Estruturais }\end{array}$ & $\begin{array}{c}\text { Unidades de } \\
\text { Processo, Máquinas } \\
\text { CNC, Bens de } \\
\text { Consumo } \\
\text { Farmacêutica }\end{array}$ & $\begin{array}{l}\text { Meio Ambiente } \\
\text { Tecnologias: } \\
\text { Desmontagem e } \\
\text { Reciclagem, } \\
\text { Consumo de } \\
\text { Serviços } \\
\end{array}$ \\
\hline $\begin{array}{l}\text { Produtos de } \\
\text { Consumo }\end{array}$ & $\begin{array}{l}\text { Têxteis (lã e } \\
\text { algodão), } \\
\text { Cerâmicas }\end{array}$ & $\begin{array}{l}\text { Têxteis, } \\
\text { Porcelana } \\
\text { Chinesa }\end{array}$ & $\begin{array}{l}\text { Diversificação } \\
\text { de Produtos } \\
\text { (importados) }\end{array}$ & $\begin{array}{c}\text { Bens Duráveis, } \\
\text { Alimento } \\
\text { Processado, } \\
\text { Turismo } \\
\end{array}$ & $\begin{array}{c}\text { Turismo e Lazer, } \\
\text { Produtos } \\
\text { Exclusivos }\end{array}$ \\
\hline \multicolumn{6}{|l|}{ Emergente } \\
\hline Energia & Carvão, Coke & Gás Urbano & $\begin{array}{l}\text { Petróleo, } \\
\text { Eletricidade }\end{array}$ & Gas, Nuclear & Hidrogênio? \\
\hline $\begin{array}{c}\text { Transporte e } \\
\text { Comunicação }\end{array}$ & Canais & $\begin{array}{l}\text { Vapor Móvel, } \\
\text { Telégrafo }\end{array}$ & $\begin{array}{c}\text { Estradas e } \\
\text { Automóveis, } \\
\text { Telefone, Rádio }\end{array}$ & $\begin{array}{c}\text { Transporte Aéreo, } \\
\text { Telecomunicações } \\
\text { Computadores }\end{array}$ & $\begin{array}{l}\text { Hipersônico?, } \\
\text { Trens Super } \\
\text { Velozes }\end{array}$ \\
\hline Materiais & Ferro Batido & $\begin{array}{c}\text { Aço } \\
\text { produzido em } \\
\text { massa }\end{array}$ & $\begin{array}{l}\text { Sintéticos, } \\
\text { Alumínio }\end{array}$ & $\begin{array}{l}\text { Materiais } \\
\text { Compostos e } \\
\text { Dedicados }\end{array}$ & $\begin{array}{l}\text { Recicláveis e } \\
\text { Degradáveis }\end{array}$ \\
\hline Indústria & $\begin{array}{l}\quad \text { Vapor } \\
\text { Estacionário, } \\
\text { Equipamento } \\
\text { Mecânico }\end{array}$ & $\begin{array}{l}\text { Química do } \\
\text { Carvão, } \\
\text { Tintas, } \\
\text { Materiais } \\
\text { Estruturais }\end{array}$ & $\begin{array}{l}\text { Química Fina, } \\
\text { Farmacêutica } \\
\text { Bens Duráveis }\end{array}$ & $\begin{array}{l}\text { Eletrônicos, } \\
\text { Tecnologia da } \\
\text { Informação }\end{array}$ & $\begin{array}{c}\text { Serviços } \\
\text { (software), } \\
\text { Biotecnologia }\end{array}$ \\
\hline $\begin{array}{l}\text { Produtos de } \\
\text { Consumo }\end{array}$ & $\begin{array}{l}\text { Porcelana } \\
\text { Chinesa }\end{array}$ & Iluminação & $\begin{array}{l}\text { Produtos } \\
\text { Duráveis, } \\
\text { Refrigeração }\end{array}$ & $\begin{array}{l}\text { Produtos de Lazer e } \\
\text { Recreação, Arte }\end{array}$ & $\begin{array}{c}\text { Pacotes } \\
\text { Integrados } \\
\text { (produtos \& } \\
\text { serviços) }\end{array}$ \\
\hline
\end{tabular}

Fonte: Adaptado de Grübler (1994). 
A mudança de paradigmas dos sistemas de produção deve ocorrer rapidamente, considerada a situação em que ocorre o desenvolvimento. Odum (1971) lança os questionamentos: Com o crescimento das áreas industrializadas, quanto tempo os sistemas naturais serão capazes de absorver e regenerar as cargas poluentes? Os sistemas antrópicos tornaram-se grandes o suficiente para dominar os fluxos da biosfera, será possível entendê-los bem o suficiente para evitar o desastre? O autor menciona a extinção dos dinossauros como um alerta para a forma de como ocorre $\mathrm{o}$ desenvolvimento, citando os pessimistas que posicionam a humanidade como a próxima na linha de extinção.

Santos (1999), ao descrever a evolução das discussões sobre a relação das sociedades e o meio ambiente, destaca o papel de Henry David Thoreau (1817-1862) na difusão de uma nova postura do homem com relação ao mundo natural, contribuindo decisivamente para que se estabelecessem os fundamentos filosóficos do movimento conservacionista. Publicado pela primeira vez em 1854, o livro "Walden ou a Vida nos Bosques", apresenta a preocupação com a devastação de florestas e a poluição de rios (THOREAU, 1984).

No século seguinte, anos sessenta, renomados cientistas no denominado "Clube de Roma" alertam para a catástrofe do sistema global. O debate ganha força, em 1972 a ONU (Organização das Nações Unidas) cria o Programa das Nações Unidas para o Meio Ambiente (PNUMA) e o Programa Observação da Terra (Earthwatch).

Presidindo a "Comissão Mundial sobre Desenvolvimento e Meio Ambiente" da ONU, Gro Brundtland lança em 1987 o documento "Our Comon Future” (Nosso Futuro Comum), um tratado sobre “desenvolvimento sustentável”.

Para Souza (2000), estes acontecimentos serviram como base, para a elaboração das propostas políticas da RIO 92 e a introdução de novos conceitos: o de "uma nova ordem econômica internacional" e "desenvolvimento sustentável".

Na Rio 92, organizada pela ONU, com a presença dos chefes de estado de 179 países, foi feito o lançamento da Agenda 21, uma lista de atividades buscando criar condições para o desenvolvimento sustentável em todo o planeta, criada como um roteiro que a humanidade deverá seguir neste século. 
Na RIO+10, (Cúpula Mundial sobre Desenvolvimento Sustentável promovida pela Organização das Nações Unidas - ONU) realizada em Johannesburgo em 2002, com 193 países participantes, segundo documento publicado pelo Conselho Nacional da Indústria, observou-se uma visão ainda voltada apenas para o crescimento econômico, sendo evidente, na década que passou, o aumento significativo da consciência mundial sobre a questão ambiental e que o desenvolvimento dos países deve, necessariamente, considerar o "avançar conjunto" do trinômio: social, econômico e ambiental (CONSELHO NACIONAL DA INDÚSTRIA - CNI, 2002).

Sem contar com a participação dos Estados Unidos da América, responsável por 25\% das emissões, o Protocolo de Kyoto que entra em vigor em 2005. Ratificado por 124 paises, é um marco na colaboração internacional para reduzir os impactos ambientais gerados pelos gases de efeito estufa. Para Carey (2004) as perspectivas de mudanças nos sistemas naturais do planeta são preocupantes, porém um indutor de competitividade na economia. A Tabela 1.2 organiza os marcos históricos nas discussões sobre as questões ambientais.

Tabela 1.2 - Evolução das Discussões Sobre as Questões Ambientais.

\begin{tabular}{|c|c|c|}
\hline 1850 & Intelectuais norte-americanos & $\begin{array}{l}\text { Fundamentos filosóficos do } \\
\text { Movimento Conservacionista }\end{array}$ \\
\hline 1960 & Clube de Roma & $\begin{array}{l}\text { Estudos da catástrofe do sistema } \\
\text { global. }\end{array}$ \\
\hline 1972 & ONU (Organização das Nações Unidas) & $\begin{array}{l}\text { Programa das Nações Unidas para } \\
\text { o Meio Ambiente (PNUMA). }\end{array}$ \\
\hline 1987 & $\begin{array}{l}\text { Comissão Mundial sobre Desenvolvimento e Meio } \\
\qquad \text { Ambiente - ONU }\end{array}$ & $\begin{array}{l}\text { Obra “Our Comon Future” lança, } \\
\text { "Desenvolvimento Sustentável”. }\end{array}$ \\
\hline 1992 & $\begin{array}{c}\text { Conferência das Nações Unidas para o Meio Ambiente } \\
\text { e Desenvolvimento - ONU }\end{array}$ & $\begin{array}{l}\text { O "Desenvolvimento Sustentável” } \\
\text { passa a ser consenso. }\end{array}$ \\
\hline 2002 & $\begin{array}{l}\text { Cúpula Mundial sobre Desenvolvimento Sustentável - } \\
\text { ONU }\end{array}$ & $\begin{array}{l}\text { Aumenta a consciência mundial } \\
\text { sobre a questão ambiental. }\end{array}$ \\
\hline 2005 & Protocolo de Kyoto & $\begin{array}{l}\text { Acordo de redução das emissões } \\
\text { (efeito estufa). }\end{array}$ \\
\hline
\end{tabular}


Considerada a dimensão das transformações necessárias os avanços são insuficientes. As taxas de consumo e emissões atingem níveis cada vez maiores. Impactos ambientais como o aquecimento global, o buraco na camada de ozônio, contaminação e escassez de recursos hídricos junto à drástica redução das reservas de insumos básicos comprometem o futuro desta economia que, de maneira perversa dita regras ao planeta (CAPRA 2003; SACHS, 2002).

Furtado (1983) propõe que na busca da reestruturação da economia mundial a orientação do processo de desenvolvimento vise impedir que as relações externas e o progresso técnico aprofundem as desigualdades sociais, e acarretem a degradação do meio físico. Os critérios de eficiência devem subordinar-se à explicitação de prioridades sociais.

A direção a seguir passa pelos mecanismos de equilíbrio e a adoção de uma nova base, adequando-se ao novo paradigma "desenvolvimento sustentável", onde o meio ambiente e o respeito ao ser humano tem igual valor aos interesses econômicos.

\subsubsection{O Conceito Desenvolvimento Sustentável}

O conceito de "desenvolvimento sustentável" foi introduzido no debate internacional pelo documento, "Our Common Future" da "World Commission for Environment and Development" (WCED) e passa a ser consenso na "Conferência das Nações Unidas para o Meio Ambiente e Desenvolvimento" que se desenvolveu no Rio de Janeiro em 1992.

Enunciado como "O desenvolvimento sustentável é aquele que atende às necessidades do presente sem comprometer a possibilidade das gerações futuras atenderem às suas próprias necessidades" WCED (1987) seu entendimento é organizado por Pearce; Markandya e Barbier (1996) e coincide com os autores, Manzini e Vezzoli (2002) que propõe três premissas básicas:

- A sociedade precisa compreender que a sua vida e das futuras gerações, dependem dos sistemas naturais do planeta, da sua qualidade e capacidade produtiva (alimentos, matérias-primas e energia).

- As condições sistêmicas nas esferas regionais e planetária, devem considerar a resiliência, definida como, a capacidade de um ecossistema sofrer uma ação negativa 
sem sair de forma irreversível da sua condição de equilíbrio, e também o seu capital natural, o conjunto de recursos não renováveis e das capacidades sistêmicas do ambiente de reproduzir os recursos renováveis.

- A premissa ética na qual cada indivíduo (incluindo as gerações futuras), tem direito à mesma disponibilidade de recursos naturais do globo terrestre.

A Figura 1.1 apresenta a síntese das premissas para o desenvolvimento sustentável como ilustração.

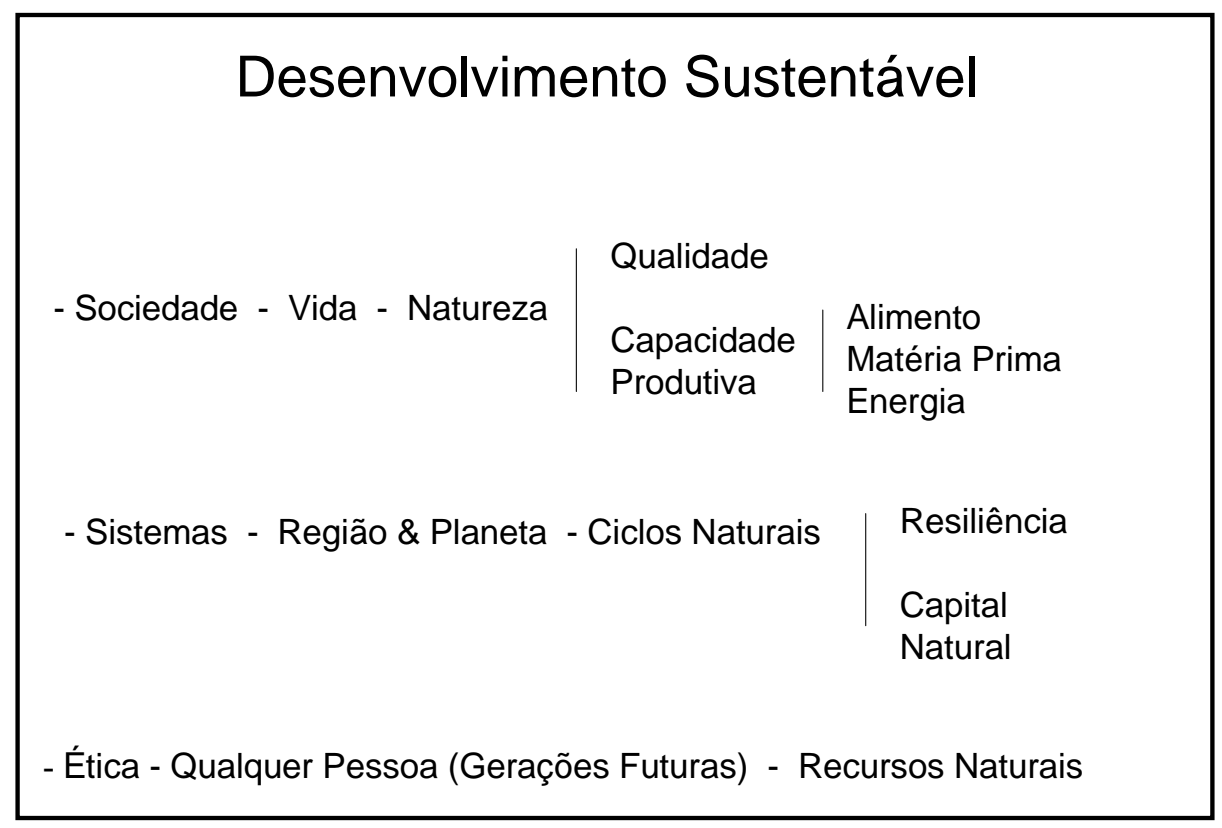

Figura 1.1 - Premissas para o desenvolvimento sustentável.

\subsubsection{Ecologia Industrial e Desmaterialização}

O roteiro proposto por Manzini e Vezzoli (2002) conduz à compreensão de como é possível estruturar os conceitos e demandas futuras.

Para que a qualidade ambiental seja conservada e as atividades humanas possam continuar indefinidamente, é necessário que as marcas de suas ações nos ecossistemas sejam imperceptíveis. Portanto, as atividades de extração e também de descarte (reintrodução), não devem resultar em empobrecimento ambiental.

Este resultado pode ser obtido seguindo duas orientações antagônicas, referentes à biosfera (conjunto dos processos naturais) e à tecnosfera (conjunto dos processos tecnológicos). 
A primeira orientação busca a máxima integração (realização de processos tecnológicos biocompatíveis: os biociclos), enquanto a segunda orientação tende à máxima nãointerferência (realização de processos tecnológicos fechados em si: os tecnociclos).

A biocompatibilidade sugere um sistema de produção e consumo que se baseie inteiramente em recursos renováveis (sem ultrapassar os limites da produtividade dos sistemas naturais que os produzem), e a sua devolução ao ecossistema como lixos totalmente biodegradáveis, separados de acordo com as suas possibilidades de renaturalização, isto é, com a sua capacidade de reconduzir às substâncias naturais iniciais, sem criar acúmulos. Trata-se de organizar os processos de produção e consumo como cadeias de transformação (biociclos) integradas aos ciclos naturais o máximo possível.

O objetivo de orientar à não-interferência é realizar um sistema de produção e de consumo fechado em si mesmo, reutilizando e reciclando todos os materiais, e formando, assim, ciclos tecnológicos (tecnociclos) cuja tendência é a de serem autônomos em relação aos ciclos naturais e, portanto, sem influência no ambiente. Este objetivo não pode ser atingido nem mesmo de forma teórica, é impossível qualquer hipótese de tecnociclos que absolutamente não interfiram na biosfera. Por isso mesmo, tal objetivo indica uma direção ou inspiração.

A partir desta discussão é possível definir "ecologia industrial" e "desmaterialização" fundamentais no percurso para a sustentabilidade ambiental.

Sistemas de produção e consumo sustentáveis, baseados em diferentes combinações de orientação para a biocompatibilidade e a não-interferência, resultando em um conjunto integrado de biociclos e tecnociclos, representam a dimensão da organização requerida. Manzini e Vezzoli (2002) definem como "ecologia industrial" este conjunto de processos produtivos diversos, mas semelhantes por provocarem um impacto no ecossistema tendendo ao nulo.

Neste contexto os ciclos tecnológicos que seguem a orientação de não-interferência só podem ser propostos em uma situação caracterizada por uma alta densidade de atividades produtivas e de consumo, pois só assim, os fluxos de matéria e energia que devem ser tratados e integrados entre si em ciclos fechados, conseguem ser 
suficientemente elevados e as distâncias suficientemente curtas para tornar a operação economicamente possível.

Por outro lado, percebe-se que as dificuldades ligadas à realização de ambas as orientações descritas aumentam proporcionalmente aos fatores quantitativos. Quanto maior for o fluxo de matéria e energia utilizado no percurso produtivo, maior será a dificuldade de torná-lo inteiramente biocompatível ou de fechá-lo em seu próprio ciclo como propõe a ecologia industrial.

Tais dificuldades são minimizadas, reduzindo o fluxo de matéria e energia no sistema produtivo, ao transferir a atenção dos processos industriais, para os produtos, visando o seu uso ou consumo. Operar desta maneira significa colocar em ação o processo de "desmaterialização" da demanda social de bem-estar, uma drástica redução no número e na intensidade material dos produtos e serviços necessários. A conseqüência é a redução de todo o fluxo de matéria e energia necessárias para o funcionamento do sistema produtivo que, aumentando a sua inteligência, com as tecnologias da informação e da comunicação, aproxima-se dos modelos da ecologia industrial.

Para ativar um processo de desmaterialização da demanda social por bem-estar é necessário propor novas soluções e combinações para a demanda e oferta de produtos e serviços (MANZINI e VEZZOLI, 2003; SELIGER, 2004). Cada uma das novas soluções será caracterizada por diferentes graus de inovação no plano técnico e, ou no plano sócio-cultural. Quando apontam para apenas uma das dimensões da inovação (mudança tecnológica ou cultural) tornam-se mais difíceis de serem implementadas como soluções sustentáveis, ilustrado na Figura 1.2.

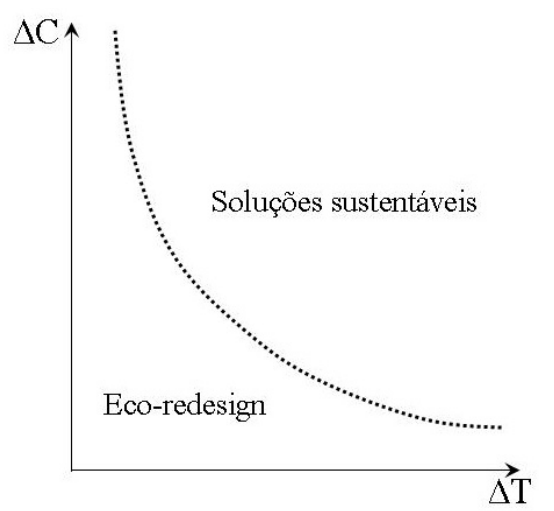

Figura 1.2 - Redesign do existente e soluções sustentáveis. Fonte: Adaptado de Manzini e Vezzoli (2002). 
Apresentadas na figura 1.3 eficiência, suficiência, eficácia são as áreas resultantes no emprego das soluções tecnológicas e culturais. A área da eficiência resulta das propostas em que a mudança técnica necessária é muito maior do que a mudança cultural. Trata-se da discussão sobre a eficiência técnica dos sistemas produtivos. Como produzir melhor serviços e produtos já existentes (sentido e razão de existir não estão em debate) e inovar as tecnologias para reduzir o consumo de recursos ambientais, mantendo o valor real do produto para os usuários.

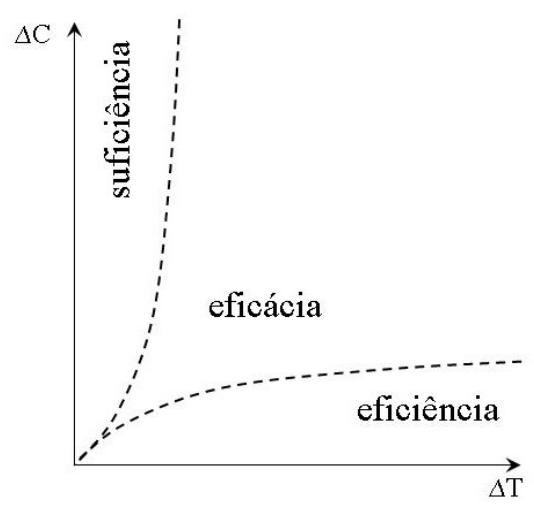

Figura 1.3 - Eficiência, suficiência e eficácia.

Fonte: Adaptado de Manzini e Vezzoli (2002).

A área da eficácia é onde as propostas apresentam equilíbrio entre a dimensão técnica e a dimensão cultural da inovação, sendo a discussão, o que poderia ser produzido e consumido (debate tanto a natureza técnica quanto o sentido do produto). Nesta área prevalece a reflexão sobre o conceito de eficácia: $\mathrm{O}$ que é melhor fazer para aumentar o bem-estar enquanto se reduzem os consumos?

Segundo Manzini e Vezzoli (2002) sustentabilidade pode ser atingida por múltiplos percursos, que são subdivididos em três famílias fundamentais.

1. Percursos na área da eficiência, partem dos atuais produtos limpos e recicláveis e chegam a soluções que operam no âmbito de uma ecologia industrial fortemente caracterizada pelos tecnociclos (conjunto de ciclos artificiais autônomos em relação aos naturais, praticamente sem interferir ou causar qualquer distúrbio significativo).

2. Percursos na área da suficiência, partem dos atuais produtos biológicos e biodegradáveis, e chegam a soluções que se colocam no âmbito de uma ecologia industrial fortemente caracterizada pelos biociclos (integração das atividades produtivas nos ciclos naturais). 
3. Percursos na área da eficácia, partem dos atuais produtos e serviços ecoeficientes (de baixa intensidade material), para chegar a propostas que se colocam no âmbito de uma ecologia industrial fortemente desmaterializada. O que significa que os processos produtivos, sejam eles, orientados à não-interferência ou à biocompatibilidade, devem tornar-se mais eficientes e apresentar produtos finais com um conteúdo maior de conhecimento e informação contribuindo para aumentar o que os autores chamam a inteligência do sistema. A Figura 1.4 proporciona a ilustração dos percursos para a sustentabilidade.

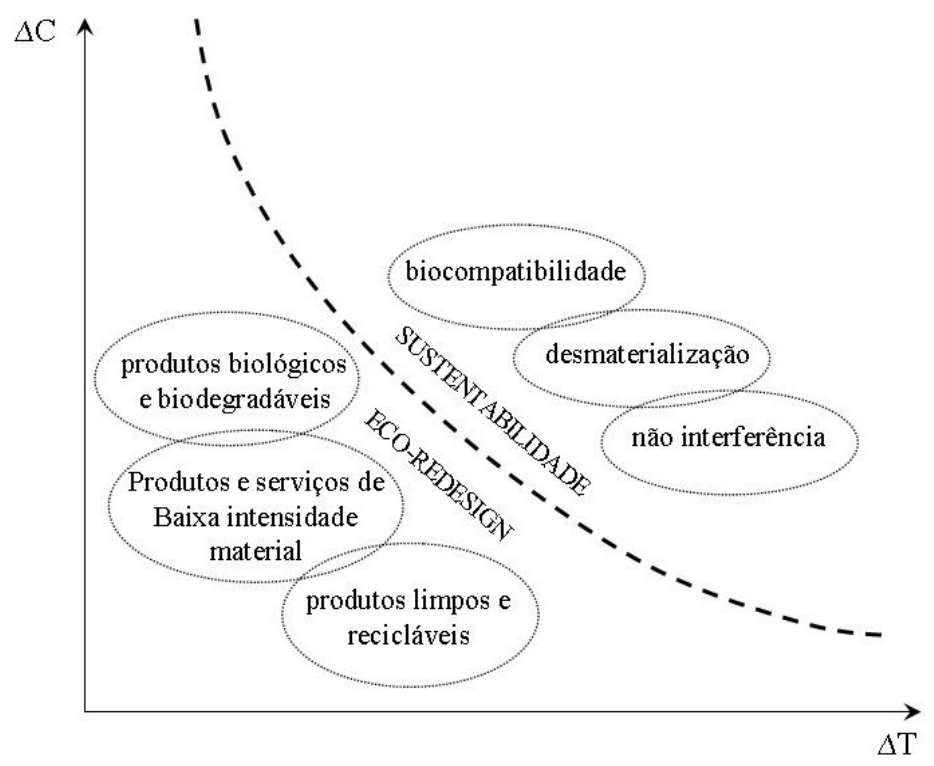

Figura 1.4 - Percursos para a sustentabilidade. Fonte: Adaptado de Manzini e Vezzoli (2002).

\subsection{Considerações Relevantes}

A perspectiva da sustentabilidade põe em discussão nosso atual modelo de desenvolvimento. Nos próximos decênios, deveremos ser capazes de passar de uma sociedade em que o bem-estar e a saúde econômica, medidos em crescimento da produção e do consumo de matéria-prima, para uma sociedade em que seja possível viver melhor consumindo muito menos. A economia deve desenvolver-se reduzindo o consumo de produtos materiais.

O resultado que deve ser atingido para podermos falar de soluções sustentáveis deve implicar em um consumo de recursos ambientais que seja (ao menos) 90\% inferior do requerido pelas soluções tidas como não sustentáveis (MANZINI e VEZZOLI, 2002). 
Como ilustração vale citar Durning1 (1992 apud SANTOS 2003). "No início dos anos 90 os americanos médios consumiam, direta ou indiretamente, $52 \mathrm{Kg}$ de materiais básicos por dia, $18 \mathrm{Kg}$ de petróleo e carvão, $13 \mathrm{Kg}$ de outros minerais, $12 \mathrm{Kg}$ de produtos agrícolas e $9 \mathrm{Kg}$ de produtos florestais".

As condições de sustentabilidade ambiental fixam alguns aspectos relativos ao fluxo físico de matéria e de energia que atravessa o metabolismo de uma sociedade, mas as características dessa sociedade podem estar em aberto. Devido à necessidade de preservação ambiental, podem ser feitas hipóteses de múltiplas sociedades sustentáveis com diferentes características. Manzini e Vezzoli (2002) ressaltam que assumir a hipótese de alcançar a sustentabilidade ambiental, não pré-define o futuro.

Se o problema, para os estudiosos da ecologia, é focalizar os aspectos físicos do metabolismo de uma sociedade, a fim de evitar a catástrofe ambiental, para outros atores sociais, em particular para os projetistas e para os produtores, o problema é como favorecer uma transição que atinja tal objetivo sustentável, sem que se verifiquem catástrofes sociais (culturais, políticas e econômicas).

A transição que se dirige para a sustentabilidade será, portanto, um grande e articulado processo de inovação social, cultural e tecnológica, no âmbito do qual haverá lugar para uma multiplicidade de opções que correspondam às diferentes sensibilidades e oportunidades diversas. Partindo das reflexões e das experiências aqui expostas, é possível desenhar os diferentes caminhos, que hoje, parecem praticáveis.

É certo, porém, que deverá verificar-se uma descontinuidade que atingirá todas as dimensões do sistema: A dimensão física (os fluxos de matéria e energia), a econômica, institucional (as relações entre os atores sociais), além da dimensão ética, estética e cultural (os critérios de valor e os juízos de qualidade que socialmente legitimam o sistema). Portanto, uma longa fase de transição já começou, trata-se então de promover a sua gestão procurando minimizar os riscos e aumentar as oportunidades.

1 DURNING, A. (1992). How much is enough? The consumer society and the future of the earth. Londres: Earthscan. (Worldwatch Alert Series). Apud SANTOS, L.G. (2003). Politizar as novas tecnologias. São Paulo: Ed.34. 


\section{A USINAGEM}

Neste capítulo está organizada a informação encontrada na literatura para respaldo ao desenvolvimento do trabalho. São apresentados o fenômeno de formação do cavaco, as direções das tecnologias para os insumos do processo e a sustentabilidade na usinagem.

Os aspectos técnicos abordados apresentam o conhecimento necessário para viabilizar as intervenções nos processos de usinagem, propondo a sua adequação ao paradigma de produção “desenvolvimento sustentável”.

Com elevada resistência mecânica, os metais e suas ligas exigem no processo de corte forças, de tal magnitude, que resultam em grande geração de calor e danos às superfícies da ferramenta e da peça. Para suportar tal condição a ferramenta deve ser uma cunha robusta que remova uma fina camada do material usinado. A camada removida deve ser fina o suficiente para que seja possível para a ferramenta e a peça suportar aos esforços de corte.

Trent e Wright (2000) enfatizam a complexidade do processo com forças e tensões elevadas resultando em altas temperaturas, desgaste da ferramenta e tensões superficiais na peça, exigindo controle e parâmetros adequados para obter a superfície desejada.

Segundo os autores, a compreensão das condições de fabricação de uma superfície usinada só é possível com o estudo da transformação do material em cavaco que, desliza sobre a superfície de saída da ferramenta. Este processo é o que consome praticamente toda a energia necessária para a usinagem. 


\subsection{Formação do Cavaco}

Para a explicação adequada dos fenômenos que ocorrem nos processos de usinagem tais como: desgaste da ferramenta, forças de corte, aresta postiça e o aquecimento da ferramenta, Ferraresi (1985) sugere o estudo do processo de formação do cavaco, e de suas variáveis, das quais as mais importantes são o material da peça, geometria e material da ferramenta, os parâmetros de corte (velocidade de corte, avanço e profundidade) e as condições de refrigeração.

Para o estudo da formação do cavaco são feitas simplificações do corte ortogonal. O esquema proposto na Figura 2.1 ilustra o mecanismo de formação do cavaco.

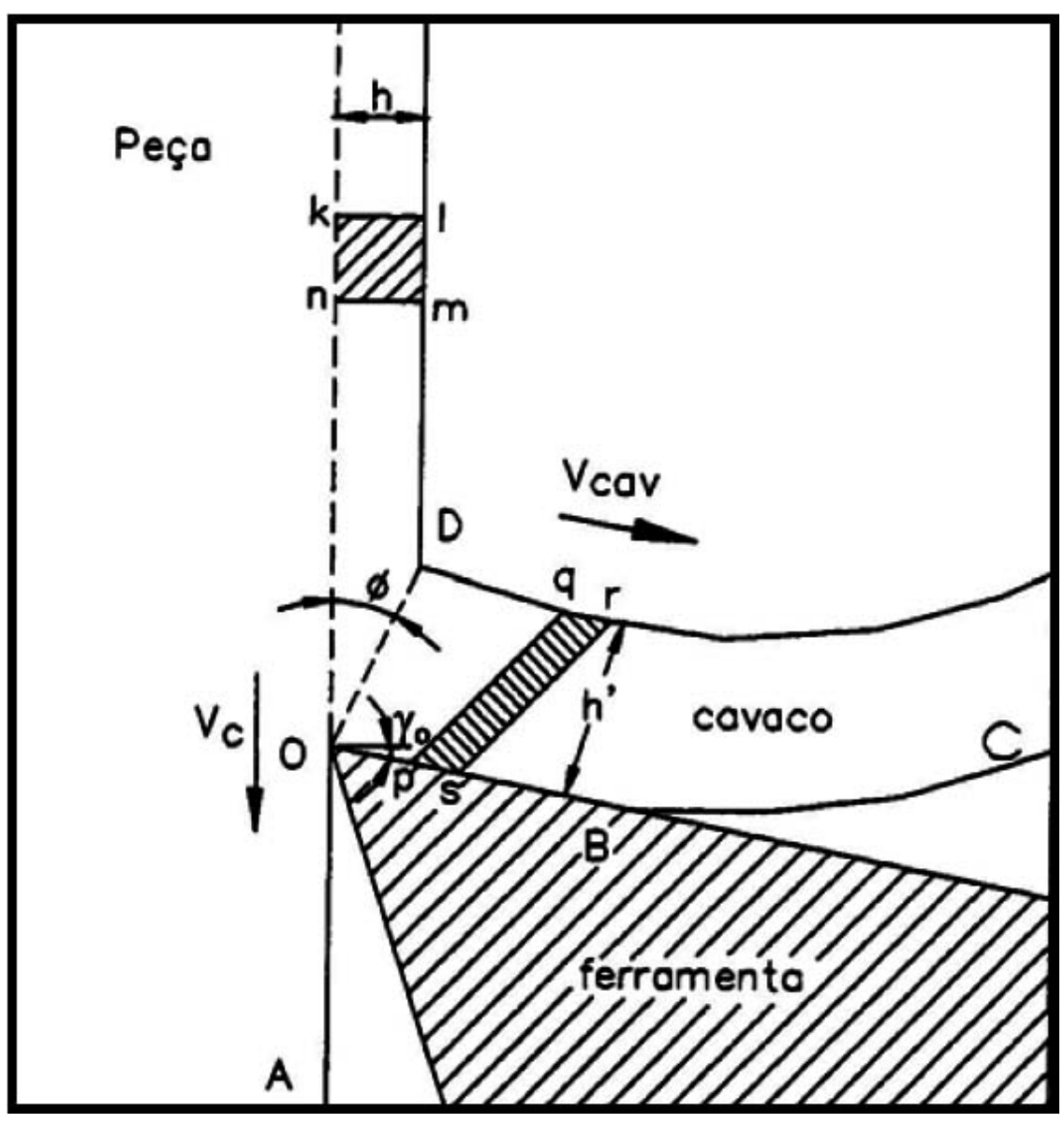

Figura 2.1 - Desenho esquemático da formação do cavaco.

Fonte: Adaptado de Trent e Wright (2000).

Considerando o volume de metal representado pela seção "klmn" movendo-se em direção a cunha cortante, a ação da ferramenta recalca este volume ("klmn") e o metal da peça começa a sofrer deformações elásticas. 
Na seqüência o limite de escoamento é vencido e o material passa a se deformar plasticamente. Esta zona, onde as deformações elásticas se convertem em plásticas, é onde ocorrem as máximas tensões tangenciais, sendo chamada, zona de formação do cavaco. Para facilitar seu estudo é representada pela linha "OD” que define o plano de cisalhamento.

Ao entrar no regime plástico, o avanço da ferramenta faz com que as tensões ultrapassem o limite de resistência do material, ainda dentro da zona de cisalhamento primária, promovendo a sua ruptura, que tem início com a abertura de uma trinca no ponto "O" se estendendo até o ponto "D" no plano definido pela linha “OD”.

Após passar pela zona de cisalhamento primaria o volume de material "klmn" se deforma plasticamente em um novo formato "pqrs". Este é um processo cíclico com as quatro etapas definidas como: recalque, deformação plástica, ruptura e movimento sobre a superfície de saída da ferramenta.

O material com novo formato, convertido em cavaco, ao movimentar-se pela superfície de saída da ferramenta, sofre grande deformação plástica, numa pequena área junto a interface com a ferramenta. Esta região é definida como zona de cisalhamento secundaria ilustrada na Figura 2.2.

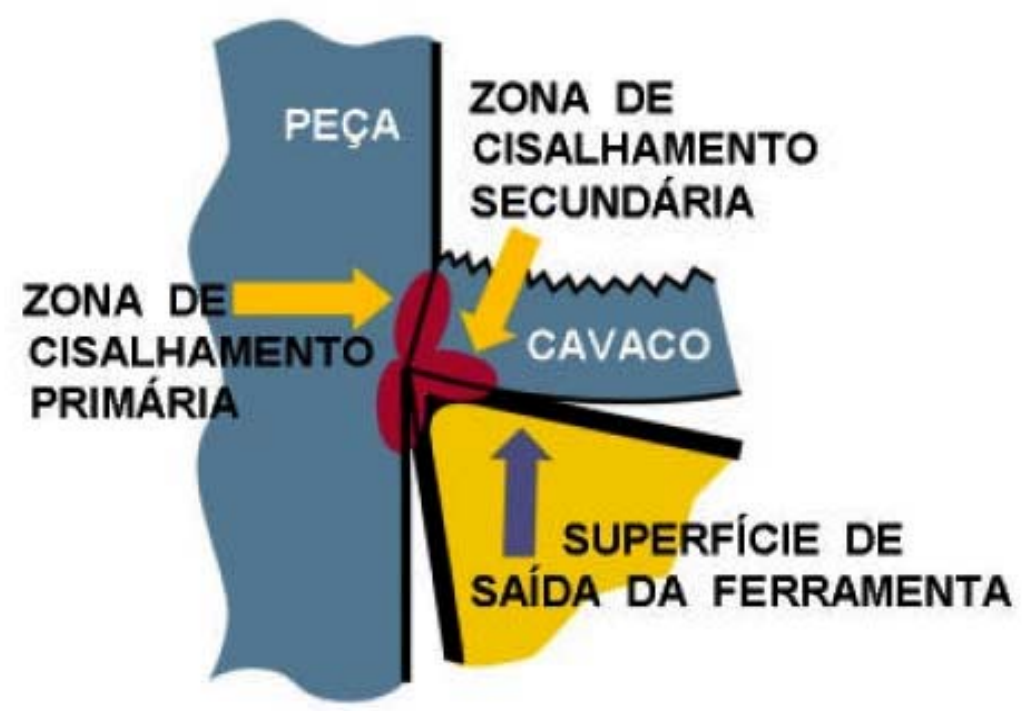

Figura 2.2 - As diferentes zonas de formação do cavaco. Fonte: Adaptado de Sandvik Coromant (2000). 
Em ambas zonas de cisalhamento, primaria e secundaria, altíssimas temperaturas comprometem a resistência da ferramenta. Para Machado e Silva (2004), ao considerar o desempenho da ferramenta, é importante o estudo do que ocorre na zona de cisalhamento secundária.

Segundo Trent e Wright (2000) as características da superfície produzida na usinagem são muito dependentes dos padrões de escoamento, tensões e temperaturas na aresta de corte. Para produzir uma superfície com alta qualidade, a condição da aresta de corte é provavelmente o item mais importante. Se durante o corte, com o desgaste, a aresta torna-se "cega" ou arredondada, as tensões superficiais na peça aumentarão.

Os autores afirmam que o quanto menos afiada estiver a aresta, campos de tensão se reproduzirão na forma de falhas nas superfícies da peça e do lado inferior do cavaco. A sua experiência demonstra que, ao apresentar um desgaste de flanco de 0,75 mm, a ferramenta está inutilizada, pois gera grandes danos à superfície da peça, reforçando que, tensões residuais, rugosidade, tolerância dimensional e aspecto visual sofrem grande influência do estado da aresta de corte.

Relacionando os fatores que afetam a usinagem Boothroyd e Knight (1989) alertam para a importância de limitar as vibrações no processo. Se elas forem relativas a taxas de remoção elevadas devem ser eliminadas com a alteração da profundidade de corte e ou do avanço.

Kalpakjian (1992) relaciona os prejuízos gerados por vibrações da estrutura da máquina ferramenta: baixa qualidade superficial, pouca precisão para tolerâncias dimensionais, desgaste prematuro, lascamento e fratura da aresta de corte, sobrecarga danificando os componentes da máquina e por fim a poluição sonora.

Machado e Silva (2004) abordam a importância de obter cavacos curtos, com baixa densidade efetiva e que, não interfiram no bom andamento do processo, oferecendo riscos ao operador, danificando a peça ou a ferramenta, obstruindo o acesso do fluido de corte e obrigando a paradas para desobstrução da área de usinagem.

Os autores orientam para a influência dos parâmetros de corte na forma do cavaco resultante, sendo possível com a variação do avanço de corte passar de cavacos longos a segmentados. 


\subsection{A Tecnologia na Usinagem}

As tecnologias de usinagem evoluem concordantes ao novo paradigma de produção o que é apresentado no artigo "Tecnologia de Corte em Avanço", de Byrne; Dornfeld e Denkena (2003). A Figura 2.3 oferece um panorama para o futuro da usinagem.

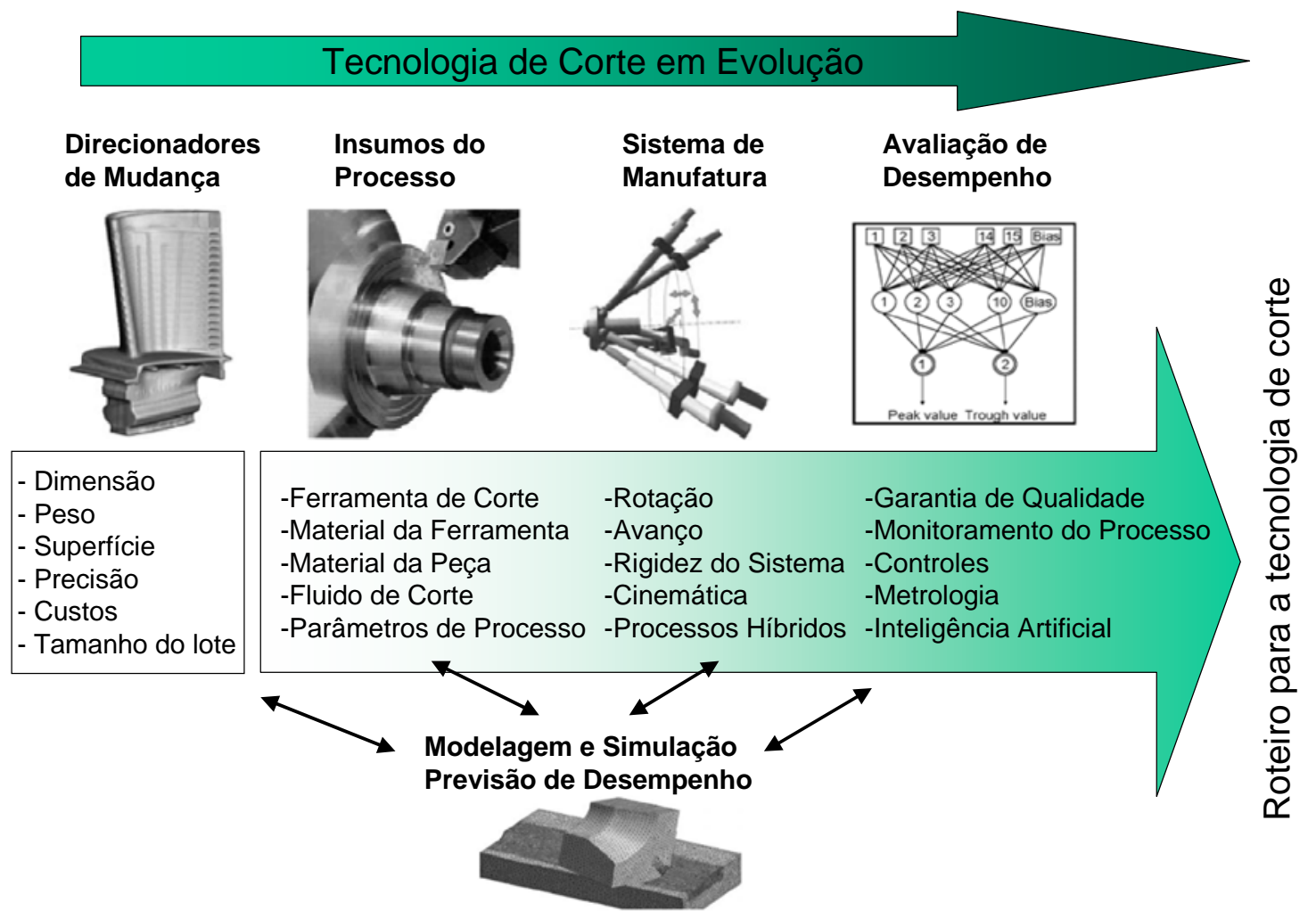

Figura 2.3 Tecnologia de corte em evolução. Fonte: Adaptado de Byrne; Dornfeld e Denkena (2003).

Os autores relacionam as direções para a usinagem e os elementos de mudança: redução do tamanho e massa dos componentes, aprimoramento das qualidades das superfícies usinadas, tolerâncias de fabricação menores e maior precisão, redução de custos e dos tamanhos dos lotes de fabricação, enfatizando o caráter multidisciplinar das tecnologias de usinagem que têm forte influência dos fatores econômicos, devendo ser abordadas por uma visão holística.

As metas de produção tendem a exigir aumento da produtividade, flexibilidade e qualidade em mercados de competitividade global e de pequenos lotes. 
As operações de corte de alto desempenho em altas velocidades, usinagem a seco e de materiais endurecidos, processos integrados, usinagem completa (apenas uma fixação) e novos materiais para ferramentas, buscam a redução significativa dos tempos produtivos e não produtivos, somando-se a minimização da poluição e do consumo de energia como desafios para o futuro.

O caráter de difícil observação de alguns fenômenos na usinagem, que não permitem avaliações por experimentos, conduzem a criação de modelos através dos quais é possível verificar a influência dos vários parâmetros do processo.

As técnicas de modelagem abrangem os aspectos interessantes aos processos de usinagem, como forças de corte (estática e dinâmica), potência, desgaste e vida da ferramenta, comportamento do cavaco (ângulo/curva/forma), aresta postiça de corte, temperaturas, condições e integridade superficial da peça, formação de rebarbas, distorção de medidas e precisão, limites de estabilidade dinâmicos e danos térmicos, em relação a ferramenta, geometria, recobrimento e influência do seu desenho. Os processos de corte ortogonal, fresamento multi-dentes, torneamento de materiais endurecidos e furação, também são estudados através da modelagem.

Áreas como usinagem de materiais endurecidos, formação de rebarbas e também dos cavacos, temperatura e desgaste da ferramenta no corte, receberam ganhos significativos no desempenho dos processos através da modelagem. Como vantagem extra, a modelagem proporciona a virtualização da experiência, resultando em processos melhor controlados, economia de materiais e de energia.

Buscando melhor controle, sistemas de sensores integrados podem disparar sinais para realizar várias tarefas, contribuindo para a otimização do processo, e num futuro próximo permitir o monitoramento da qualidade da peça que está sendo usinada.

\subsection{A Ferramenta}

O desenvolvimento dos processos requer a adaptação das ferramentas às tecnologias de usinagem, que sofrem grande solicitação mecânica, principalmente no corte a seco e em altas velocidades. Segundo Trent (1996), “toughness" é a qualidade mais importante para um material de ferramenta, sem medida para tal grandeza, é definida pelo autor, como a capacidade de continuar cortando em condições difíceis por longos períodos 
sem a fratura da aresta de corte. Machado e Silva (2004) a definem como: "tenacidade suficiente para evitar falha por fratura". Byrne; Dornfeld e Denkena (2003) definem "toughness" como: fator de intensidade da tensão crítica, que determina a concentração de tensões necessárias no começo de uma trinca para a sua propagação. Estes autores enfatizam que as propriedades da ferramenta devem sofrer poucas variações nas altas temperaturas que ocorrem durante a usinagem e a importância de suportar choques térmicos.

O material de corte ideal combina a dureza elevada à tenacidade e estabilidade química. Dureza e tenacidade são antagônicas, e não existe material que proporcione estas propriedades simultaneamente. Buscando combinar as três características são aplicados revestimentos às ferramentas em camadas resistentes ao desgaste sobre uma superfície tenaz. A espessura destas camadas deve estar entre 3-10 $\mu \mathrm{m}$, sendo a combinação e seqüência determinadas pela aplicação de corte.

\subsubsection{Materiais Para Ferramentas}

Carbetos: as ferramentas feitas pela metalurgia do pó são compostas de materiais metálicos duros (carbetos) e metais tenazes do grupo do ferro (ligante). O metal duro mais comum é o carbeto de tungstênio (WC), uma combinação de cobalto na forma de pó e carbeto de tungstênio sinterizados.

Cermets: com o advento da usinagem a seco os cermets passam a receber mais atenção em seu desenvolvimento. A microestrutura dos cermets, similar a dos carbetos, consiste de uma matriz ligante de cobalto e níquel, que contém as partículas do material duro, carbonitretos de titânio ( $\mathrm{TiCN}$ ) com diferentes proporções de tântalo $(\mathrm{Ta})$, tungstênio (W) e algumas vezes molibdênio (Mo). Cermets contendo nitrogênio apresentam tenacidade comparável a dos carbetos convencionais e excelente resistência à oxidação. Os cermets conservam durezas elevadas em altas temperaturas, proporcionando altas velocidades de corte, com estabilidade química, grande resistência na aresta de corte, resultando em boa qualidade superficial para a peça. Por serem mais frágeis que os carbetos cementados, tem limitações como velocidades de avanços menores. Por suas propriedades os cermets são a ligação entre as ferramentas de corte de cerâmica (duras e frágeis) e as de carbetos cementados. 
Cerâmicas: existem dois tipos de ferramentas de corte com matriz de cerâmica. O óxido de alumínio (alumina) proporciona fortes ligações iônicas resultando em características desejáveis à ferramenta, pode ser combinado com materiais duros como carbetos para mudar as propriedades mecânicas da matriz. O nitreto de silício $\left(\mathrm{Si}_{3} \mathrm{H}_{4}\right)$ proporciona boa resistência em altas temperaturas, à oxidação e ainda baixo coeficiente de dilatação térmica, em comparação a outros materiais cerâmicos oferece boa resistência a choques térmicos, podendo ser de três tipos principais: "Reaction Bonded Silicon Nitride (RBSN), Hot Pressed Silicon Nitride (HPSN) e Sintered Silicon Nitride (SSN).

Nitreto de Boro: existem diferentes formas de cristal de nitreto de boro, na forma de grafite, também chamado de nitreto de boro hexagonal, é conhecido por sua qualidade lubrificante e baixa dureza, em contraste à estrutura cúbica $(\mathrm{CBN})$, dura e abrasiva usada nas ferramentas de corte. O CBN tem a mesma estrutura do diamante e propriedades semelhantes, sendo o segundo material em dureza. O material sintético, composto de grãos de nitreto de boro cúbico e um ligante especial de cerâmica tem excelentes propriedades, como alta dureza e pouco desgaste químico em temperaturas de até 1400 Celsius, apresentando bom desempenho em operações de usinagem em altas velocidades.

Diamante: diamante Monocristalino (MCD) é o material mais duro. Esta dureza se deve a sua estrutura cristalina. É possível sintetizar diamantes em pressões e temperaturas extremamente altas. Devido à tenacidade superior as ferramentas de corte são fabricadas com diamante policristalino (PCD). O diamante oferece uma respeitável combinação de propriedades químicas, físicas e mecânicas como: baixo coeficiente de atrito e dilatação térmica, alta resistência à corrosão química e resistência mecânica, mas também tem suas limitações, por ser meta estável, quando aquecido acima de 600 Celsius em contato com oxigênio forma uma camada negra e pela afinidade química entre carbono e ferro, a usinagem de materiais ferrosos com diamante resulta em acentuado desgaste da ferramenta.

\subsubsection{Manufatura da Ferramenta de Corte}

A qualidade das ferramentas recobertas é influenciada por diversos fatores, dentre eles a manufatura do substrato e os mecanismos de recobrimento. O substrato determina a geometria e tenacidade, sendo as propriedades tribológicas dependentes das camadas 
depositadas. A zona entre o substrato e as camadas superficiais é chamada interface, e determina a adesão do filme. O material sinterizado passa por vários processos até a obtenção da ferramenta acabada. Na retificação é determinada a geometria e a qualidade superficial, sendo a retificação e o recobrimento, os processos de maior custo na fabricação das ferramentas.

A quantidade de camadas possíveis é quase ilimitada. As camadas de recobrimento podem ser aplicadas por dois processos, o CVD (chemical vapour deposition) que tem como fator crítico as altas temperaturas de deposição (acima de 800 Celsius),gerando tensões residuais, e o PVD (physical vapour deposition) que vem ganhando importância nos últimos anos por temperaturas de processo menores (entre 300 e 500 Celsius) e proporcionar grande flexibilidade de materiais possíveis.

Ferramentas usadas na usinagem a seco oferecem melhor comportamento ao desgaste quando a retificação do substrado prevê características específicas. A resistência da interface, do recobrimento PVD, depende da qualidade superficial do substrado. Enquanto para a usinagem com fluido a resistência da interface de uma ferramenta de carbeto com recobrimento PVD é suficiente, devido aos grandes esforços na interface durante a usinagem a seco, o recobrimento PVD chega a fragmentar-se em partículas.

Camadas CVD diamante grossas tem apresentado bons resultados na usinagem de materiais não ferrosos oferecendo excelente resistência ao desgaste abrasivo e resistência térmica. Para as camadas CVD diamante finas o problema é adesão, e está sendo pesquisado.

O desgaste de uma ferramenta é resultado do atrito e das cargas térmicas na zona de contato entre cavaco e ferramenta, uma camada dura altera a condição de atrito entre o par cavaco ferramenta. $\mathrm{O}$ atrito é reduzido pela camada que favorece o deslizamento do cavaco e diminui zona de contato, reduzindo a carga térmica para a ferramenta.

Atualmente, com as técnicas CVD e PCVD, é possível aplicar sobre carbetos camadas multi-componente e multi-fase contendo, carbonitretos, nitretos e óxidos de titânio, zircônio, háfnio e alumínio.

As camadas auto lubrificantes são aplicadas em ferramentas para a usinagem a seco, buscando a redução do atrito e conseqüentemente do calor no processo. 
Camadas de baixa dureza como $\mathrm{MoS}_{2}$-base apresentam bons resultados, assim como DLC (diamond like carbon), a matriz de carbono explica as boas propriedades tribológicas, os componentes metálicos são W, Ta ou Nb em concentrações de 5 a 15\%.

\subsubsection{Geometria da Ferramenta de Corte}

Segundo Byrne; Dornfeld e Denkena (2003) o desenvolvimento das ferramentas de corte ocorreu através da otimização da macro-geometria e de materiais de corte e recobrimento com melhor desempenho. Atualmente, pesquisas mostram que é possível otimizar a usinagem, melhorando a qualidade superficial da aresta de corte e também com a caracterização de formas definidas em sua geometria. Caracterizações no passado determinavam apenas o raio da aresta de corte $r_{\beta}$. No entanto a forma de um arco de circunferência não define a melhor geometria, e são introduzidos quatro novos parâmetros: $\Delta \mathrm{r}, \varphi, \mathrm{S} \gamma, \mathrm{S} \alpha$, permitindo assim uma melhor caracterização das formas para a aresta de corte. A Figura 2.6 apresenta desenho destes novos parâmetros.

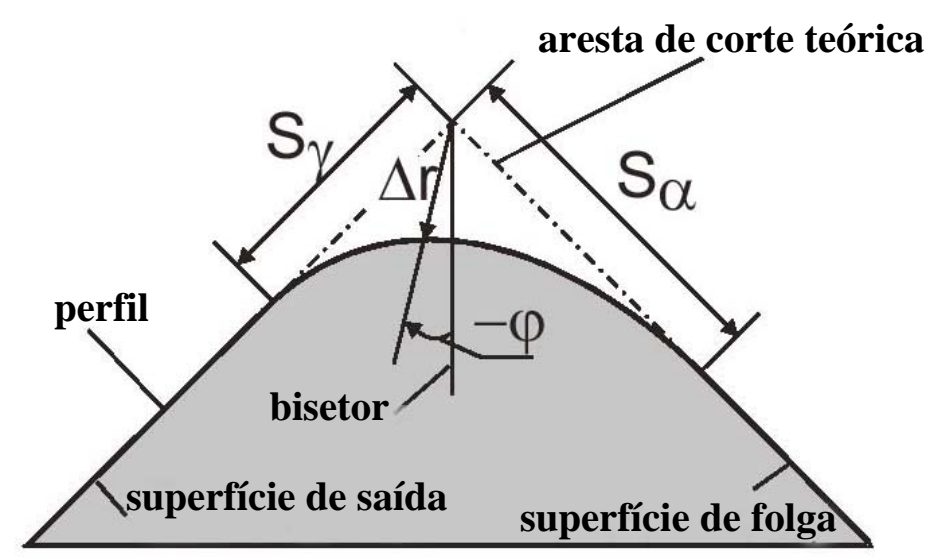

Figura 2.6 - Parâmetros de caracterização da geometria da aresta de corte. Fonte: Adaptado de Byrne; Dornfeld e Denkena (2003).

$\mathrm{O}$ valor $\Delta \mathrm{r}$ define o tamanho do formato chanfro, o ângulo $\varphi$ o direcionamento da ponta de corte, para a superfície de saída ou superfície de folga, os parâmetros $\mathrm{S} \gamma$ e $\mathrm{S} \alpha$ a abertura aguda ou obtusa para as respectivas superfícies. Estes parâmetros podem ser verificados automaticamente com o auxílio de uma máquina de medição, e adaptados às condições de usinagem podem conduzir a menores forças de corte, proporcionando melhor qualidade na superfície usinada e maior vida para a ferramenta. Eles permitem, de maneira prática, a definição de uma geometria para a aresta de corte necessária a um processo de usinagem com grande eficiência. 


\subsection{Materiais para Usinagem}

Os diferentes ramos da indústria direcionam as demandas por diferentes materiais de engenharia, os quais devem ter baixa densidade e alta resistência, além da facilidade em serem trabalhados. A taxa de remoção de material é o objetivo principal para a otimização de um processo de corte de alto desempenho sendo calculado pela seção do cavaco e a velocidade de corte. A possibilidade de ajustar estas variáveis é dependente da combinação das tecnologias de corte e a tarefa de usinagem. Para a maioria dos materiais as taxas estão na faixa $\mathrm{Qw}=150$ a $1500 \mathrm{~cm}^{3} / \mathrm{min}$ (Byrne; Dornfeld e Denkena, 2003). Com as pesquisas a tendência é aumentar as taxas de corte. O incremento das taxas de remoção de material é função das características específicas das tecnologias de usinagem e das propriedades do material a ser usinado. Atualmente a usinagem em altas velocidades é realizada principalmente para os metais de liga leve como o alumínio e o magnésio. Estes materiais geram uma carga térmica e mecânica relativamente baixa para a ferramenta. Alguns desenvolvimentos importantes em usinabilidade dos materiais são: aços endurecidos, aços de corte fácil, materiais de liga leve e aeroespaciais.

\subsubsection{Usinagem de Aços Endurecidos}

O desempenho de peças usinadas é, fortemente influenciado pelos processos de acabamento, que representam a etapa final na cadeia de processos. Grande flexibilidade e a capacidade de executar peças de geometria complexa em uma única fixação estão entre as principais vantagens do torneamento de materiais endurecidos sobre a operação de retificação.

Um desenvolvimento recente é a aplicação de um processo de conformação após o torneamento de materiais endurecidos, que pode ser executado na mesma máquina. Neste processo uma esfera cerâmica, através de um suporte hidrostático, é comprimida contra a superfície usinada. O deslocamento da esfera permite o "burnishing" da superfície, a pressão aplicada por um mancal hidrostático determina a força adequada para a operação. Tensões de contato elevadas podem ser obtidas através deste processo de deformação plástica que suaviza a rugosidade, aumenta a dureza superficial e induz tensões residuais de compressão elevadas, contribuindo para aumentar a vida do componente usinado. 


\subsubsection{Aços de Corte Fácil}

Aços de corte fácil são interessantes para grande escala de produção, com máquinas automáticas, proporcionando, velocidades de corte elevadas, maior vida da ferramenta, boa qualidade superficial, forças de corte menores e conseqüentemente menor consumo de energia, como vantagem adicional cavacos pequenos e quebradiços. O custo extra destes materiais é compensado com os ganhos de produtividade e confiabilidade do processo.

Os aços mais comuns são a base de enxofre que com o manganês forma o sulfeto de manganês (MnS), com a adição de chumbo é possível obter reduções do atrito na zona de contato, entre a peça e a ferramenta, com temperaturas de corte até $30 \%$ menores em relação a aços sem chumbo (BYRNE; DORNFELD e DENKENA, 2003).

O chumbo por ser tóxico deve ser evitado nos processos industriais, no entanto, no passado foi muito empregado. Segundo Trent e Wright (2000) usinabilidade não é uma propriedade do material e sim o comportamento durante o corte, portanto condições devem ser especificadas. Como exemplo cita os aços com inclusões de cálcio que ao serem usinados com carbetos proporcionam aumento significativo da vida da ferramenta.

Pesquisas conduzidas atualmente visam a substituição do chumbo por cálcio, estanho, bismuto e enxofre usando os dados de aços normais e com chumbo como referência. A Figura 2.7 ilustra a condição em que o atrito é reduzido conduzindo a menores temperaturas e forças de corte, proporcionando maior vida à ferramenta.
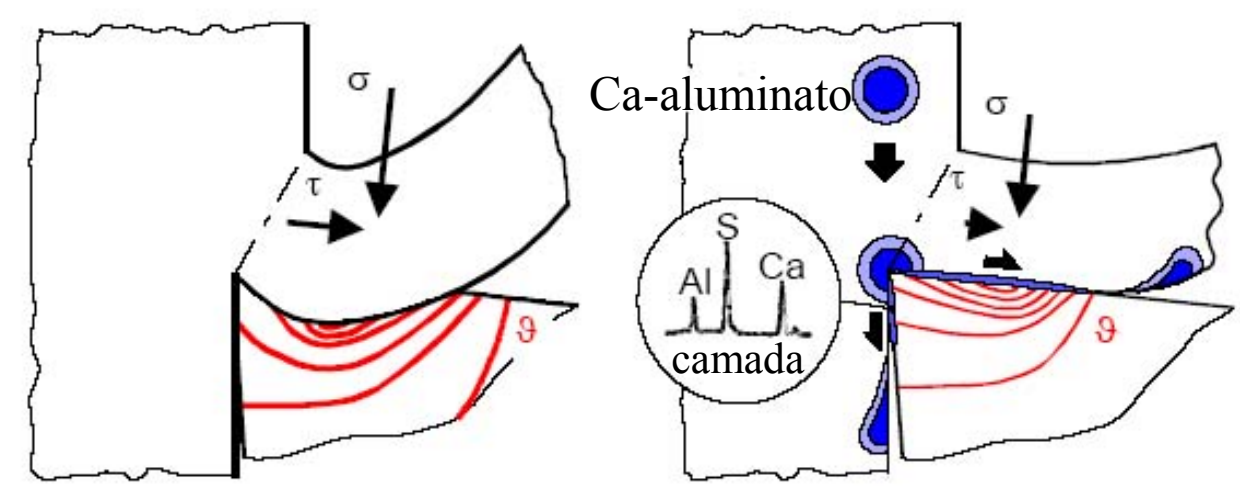

Figura 2.7 - Ilustração do mecanismo de formação de camada em aços com cálcio. Fonte: Adaptado de Byrne; Dornfeld e Denkena (2003). 


\subsubsection{Usinagem de Materiais Fundidos}

O desenvolvimento dos ferros fundidos tem avançado bastante, possibilitando a manufatura de componentes fundidos que eram obtidos por outros meios.

Dois novos materiais merecem destaque "Compacted Graphite Iron" (CGI) e "Austempered Ductile Iron" (ADI), oferecem resistência superior com estruturas de grafite lamelar (CGI) e grafite globular (ADI). A usinagem do CGI requer maior potência e desenvolvimento de estratégias diferentes das empregadas na usinagem dos ferros fundidos laminares, a nova forma do grafite e a ausência das camadas de magnésio enxofre $(\mathrm{MnS})$, exige o emprego de materiais de corte duros e velocidades de corte convensionais.

O ADI é um desenvolvimento do ferro fundido globular, proporcionando uma combinação pouco usual de grande resistência, alta ductibilidade e tenacidade elevada resultantes de um tratamento térmico especial, "austêmpera". A explicação para as propriedades mecânicas, é a estrutura de grão base austenita-ferrita, também chamada ausferrita.

Alta resistência mecânica, a abrasão e ductibilidade elevada conduzem a um incremento na carga térmica e mecânica na aresta de corte. No torneamento a seco com pastilha de metal duro do tipo K10 acontece o desgaste por crateras. As velocidades de corte empregadas na usinagem do ferro fundido globular (acima de $200 \mathrm{~m} / \mathrm{min}$ ) devem ser reduzidas para a faixa entre 140 e $180 \mathrm{~m} / \mathrm{min}$ para cortar o ADI. A maior solicitação de corte conduz a uma redução significativa na vida da ferramenta.

\subsubsection{Usinagem de Metais de Liga Leve}

O alumínio, nas formas fundido ou forjado, tem ampla variedade de aplicações, tanto para a produção em lotes pequenos ou médios como na produção em massa. A usinabilidade do alumínio depende de seus elementos de liga, estrutura granular e tratamento térmico. O alumínio tem grande tendência a aderir na aresta de corte, prejudicando a ferramenta, e cavacos longos e dúcteis dificultam a usinagem.

O magnésio tem sido empregado em soluções que exigem baixo peso, tendendo a aumentar a demanda por peças fundidas, que obtidas por este processo apresentam boa 
usinabilidade. As ligas como AZ91hp são praticamente isentas de partículas abrasivas e pouco suscetíveis a adesão à aresta de corte, resultando em pequeno desgaste da ferramenta. As velocidades de corte empregadas são altas, da ordem 4000 a 6000 $\mathrm{m} / \mathrm{min}$. As forças de corte resultantes da usinagem do magnésio são aproximadamente $30 \%$ menores se comparadas às ligas de alumínio hipo-eutéticas.

Por sua estrutura cristalina os cavacos são curtos e quebradiços e as condições de corte tendem a melhorar em temperaturas acima de 220 Celsius. A usinagem a seco está sendo pesquisada e as abordagens são segurança e controle térmico do processo. $\mathrm{O}$ diamante policristalino (PCD) é a melhor opção para usinar o magnésio, proporcionando vida extremamente longa para a ferramenta e qualidades superficial e dimensional muito boas para a peça.

\subsubsection{Materiais Compostos}

O corte destes materiais é diferente dos materiais convencionais e suas ligas, além da não homogeneidade, depende da influencia dos diversos materiais de reforço e da matriz. A ferramenta é submetida à alternância destes materiais cuja resposta ao corte pode ser completamente diferente. O tipo de fibra, a arquitetura de reforço e o tipo de matriz são os fatores determinantes para a escolha da ferramenta e dos parâmetros de corte. No caso de polímeros reforçados com fibra de vidro a escolha da ferramenta é feita pelo material de corte, já para polímeros reforçados com fibra de carbono a geometria da ferramenta é o que determina a escolha. A dureza das fibras de vidro ou de carbono provoca grande desgaste nas ferramentas.

Tecnicamente conhecidos como material composto, as ligas de alumínio reforçadas com fibra de cerâmica, tem sua usinabilidade dependente do tipo e forma do reforço e da forma pelo qual o reforço é introduzido na matriz, sendo também importante sua dureza e distribuição na matriz. Dada a intensidade do desgaste gerado pelos mecanismos de abrasão e adesão a única alternativa viável para o corte destes materiais é o uso de diamantes.

\subsubsection{Usinagem de Materiais Aeroespaciais}

Para os materiais clássicos na construção de turbinas, as ligas de titânio e níquel, as ferramentas de corte de alto desempenho (carbetos de tungstênio, cerâmica reforçada, 
diamante policristalino PCD, nitreto de boro cúbico policristalino) proporcionam um enorme aumento nas taxas de remoção de material e na produtividade. Os titânioaluminídios (TiAl) e os compostos de matriz metálica de titânio estabelecem novas demandas para os processos de usinagem. O corte destes materiais é difícil por sua baixa condutividade térmica, a natureza frágil e a grande afinidade química com todos os materiais de corte conhecidos.

Para as operações de torneamento, são usadas ferramentas de carbeto de tungstênio de grão fino ou as convencionais, sem recobrimento, KW-K10 ou HW-K20 de carbeto de tungstênio. Dependendo das propriedades do material a ser usinado as velocidades de corte não devem ultrapassar $50 \mathrm{~m} / \mathrm{min}$ e o avanço $0.12 \mathrm{~mm} /$ rot. Atualmente, cerâmica, PCD e CBN não são alternativa econômica para os carbetos de tungstênio.

O titânio-aluminídio se destaca por seu comportamento frágil, fazendo com que não só a escolha da ferramenta e condições de corte, como também a qualidade superficial da peça usinada seja de central importância.

A usinagem de peças de TiAl oferece um desafio duplo, de um lado a curta vida da ferramenta e as baixas velocidades de corte e por outro lado a qualidade da superfície resultante, colocando novos desafios para a usinagem de alto desempenho.

\subsection{Fluidos de Corte}

Frederick W.Taylor, em 1890, demonstrou que um grande fluxo de água sobre a região de contato entre a peça e a ferramenta, permitia que as velocidades de corte fossem dobradas ou triplicadas, dando início à aplicação dos fluidos de corte nas operações de usinagem.

A água com seu excelente poder de refrigeração não oferece lubrificação para as superfícies de atrito além de provocar a oxidação de alguns dos materiais usinados ou componentes da máquina.

Muito utilizados os fluidos de corte, aprimorados, são atualmente de composições complexas, contendo agentes químicos que variam de acordo com o tipo de operação a ser executada e os metais a serem trabalhados. 


\subsubsection{Tipos de Fluidos de Corte}

Nachtman (1989) organiza os fluidos de corte empregados usualmente na indústria em soluções e emulsões.

As soluções consistem de um fluido base ou uma composição de duas ou mais bases, com diferentes propriedades, que proporcionam um fluido de corte com as características desejáveis que podem ser aperfeiçoadas por aditivos como: extrema pressão (EP), inibidores de corrosão, detergentes, anti-atomizantes, anti-espumantes, máscara de odor, corantes e biocidas. As bases mais comuns são, óleos de origem mineral ou vegetal, ésteres, poliglicóis ou água.

As emulsões são compostos de duas fases, uma fase contínua (água) e uma descontínua composta de pequenas partículas de óleo ou fluido sintético em suspensão na água. Os óleos de corte (com a ação de um emulsificador) são misturados à água em proporções que podem variar, sendo bastante utilizado em torno de $5 \%$.

As soluções à base de óleos são empregadas em situações que requerem características de lubrificação não sendo tão eficientes como a água na refrigeração. Os óleos minerais oferecem boa proteção à oxidação e vida longa, são de fácil reciclagem, mas agressivos ao operador e meio ambiente, além de ser recurso de fonte não renovável. Os óleos de origem vegetal são preferidos por questões ambientais, em contrapartida são mais caros, suportam temperaturas menores e se degradam mais facilmente. Ambos podem receber aditivos para aprimorar características específicas.

A água com sua excelente capacidade de refrigeração, proporciona a formulação de emulsões e soluções de bom desempenho nas operações de corte e melhores condições para o operador e ambiente de trabalho. No entanto exigem a retirada de óleos estranhos (contaminação) e o controle de micro-organismos perigosos à saúde do operador e prejudiciais às características de corte. Ao serem descartados, estes fluidos, devem receber tratamento físico químico para a separação da água, que deve atingir padrões de descarte da rede pública de coleta de águas. O óleo deve ser enviado para reciclagem e os resíduos sólidos encaminhados ao destino adequado.

As soluções desenvolvidas para as necessidades da indústria são estáveis e oferecem proteção anticorrosiva, tem poder detergente, proporcionam boa visibilidade da região 
de corte e facilidade no preparo sendo alternativa viável quando comparados os custos totais e restrições ao emprego dos fluidos convencionais.

Segundo Byrne, Dornfeld e Denkena (2003) pesquisas buscam adequar a utilização de gases em larga escala, dos quais o ar atmosférico é o mais comum. Argônio, hélio e nitrogênio são utilizados, em alguns casos, para prevenir a oxidação da peça e dos cavacos. Gases como o $\mathrm{CO}_{2}$, com o ponto de ebulição abaixo da temperatura ambiente, podem ser comprimidos e injetados na região de corte promovendo sua refrigeração, porém, grandes gradientes térmicos devem ser evitados, impedindo distorções das peças e o surgimento de tensões residuais.

\subsubsection{O Contexto na Usinagem}

Através de pesquisa conduzida na indústria automotiva alemã verificou-se que na composição de custos da peça de 7 a 17\% eram relativos aos fluidos de corte e custos com ferramentas de 2 a 4\% (KLOCKE e EISENBLAETTER, 1997). Nos custos gerados pelo emprego de fluidos de corte deve-se considerar a operação de manufatura, o componente, qualidade exigida da peça, o arrasto do fluido de corte, vaporização, o lubrificante envolvido, o tipo de máquina, o tamanho das instalações, a situação do prédio, processamento e disposição do fluido e outros fatores (KLOCKE e EISENBLAETTER, 1997). As perdas de fluidos no sistema de manufatura ocorrem através da vaporização, araste com as peças e cavacos, nos componentes da máquina, assim como nos sistemas de ar comprimido e vácuo conduzindo a vazamentos e atomização. Os vazamentos além de representarem perdas podem prejudicar o sistema hidráulico da máquina. Estima-se que, 30\% do consumo anual de fluidos de corte são perdidos pelos meios acima relacionados, tornando-se evidente este ser um aspecto que comporta otimização.

\subsubsection{Aspectos Ambientais}

Considerando os aspectos ambientais da usinagem, os fluidos de corte merecem atenção especial. O seu emprego tem sido questionado não só pelo desempenho ecológico, mas também econômico. O estudo dos fluidos de corte se divide nas seguintes disciplinas: química, tecnologia do processo, tecnologia de manufatura, conservação ambiental, medicina e tribologia. 
Os autores Droy e Randles (1999) e também Mang e Dresel (2001) exaltam as qualidades do fluido de corte, do tipo sintético, "polialquileno glicol" (PAG), que oferece excelente refrigeração e boa lubrificação nas operações de corte, é de baixa toxicidade para o operador, reciclável e seu tratamento não oferece dificuldades.

A disposição do fluido de corte é aspecto relevante em relação ao meio ambiente. Walter (2005) alerta para a coleta obrigatória dos fluidos de corte usados, determinada pela legislação brasileira, através da Resolução número 9 de 31 de agosto de 1993 do Conselho Nacional para o Meio Ambiente (CONAMA). Os fabricantes têm como objeto de estudo, aumentar a vida dos fluidos com manutenção de alta qualidade e monitoramento, chamado gerenciamento dos fluidos.

Para que processo de manufatura seja ambientalmente adequado em relação aos fluidos de corte são relacionados os seguintes pontos:

- A composição do fluido de corte não pode comprometer a saúde do trabalhador ou do meio ambiente;

- Durante sua aplicação os fluidos não devem gerar contaminantes ou afetar os componentes e vedações da máquina;

- A zona de corte não deve ser inundada. Minimizar a aplicação visando apenas a refrigeração e lubrificação durante o corte;

- O monitoramento contínuo do fluido de corte e o ambiente dentro da máquina através de sensores;

- Através de manutenção e gestão é possível reduzir os consumos de água e óleo e conseqüentemente a produção de resíduos e custos de produção;

Para as organizações de manufatura, envolvidas em operações de usinagem, é crescente o interesse pelos fluidos de corte, abordando as questões, ambiental, saúde, econômica e de segurança. Os fluidos, usualmente, são compostos de hidrocarbonetos, enxofre, fósforo, cloro, emulsificantes e biocidas. $\mathrm{O}$ vazamento, outras perdas, ou disposição imprópria, pode contaminar lagos, rios e a água do lençol freático. O tratamento dos fluidos de corte reduz significativamente os riscos para o meio ambiente, mas não elimina o perigo de contaminação. Estudos indicam que os trabalhadores expostos a fluidos de corte, através de contato com a pele e inalação, tem propensão a desenvolver problemas de saúde. Finalmente cabe ressaltar os custos associados à compra, manutenção, tratamento, controle do vapor, recirculação e disposição representam motivação adicional para que a indústria de manufatura examine cuidadosamente as decisões de empregar fluidos de corte. 


\subsubsection{Alternativas ao Emprego dos Fluidos de Corte}

A usinagem a seco elimina grande parte os problemas ambientais causados pelos fluidos de corte, no entanto as partículas geradas na usinagem representam riscos à saúde (irritação da pele e inalação) além do risco de explosão da poeira metálica que não é menos inflamável que o óleo atomizado (BYRNE, DORNFELD e DENKENA, 2003). Os ganhos ambientais, de saúde, segurança e econômicos proporcionados pela transição para a usinagem a seco devem ser avaliados pelas medidas de desempenho do processo.

A introdução da usinagem a seco requer medidas de adaptação para compensar as funções primárias do fluido. Isto requer o entendimento das complexas relações entre o processo, ferramenta, peça e máquina ferramenta (KLOCKE e EISENBLAETTER, 1997). Em alguns casos não é possível a usinagem a seco, por exemplo, quando há forte adesão entre a ferramenta de corte e o cavaco, conduzindo a desgaste excessivo da ferramenta. Outra situação crítica é quando a deformação térmica da peça não pode ser controlada. Tolerâncias de dimensão e de forma, apertadas, podem ser restrição para a usinagem a seco.

As ferramentas de corte para a usinagem a seco devem incorporar mudanças no desenho relativas ao substrato, o recobrimento e a geometria, proporcionando baixo atrito na zona de contato peça ferramenta e grande resistência em altas temperaturas. O processo na usinagem a seco deve ser desenvolvido buscando a minimização do fluxo de calor para a peça. Isto pode ser conseguido reduzindo as forças de corte e dirigindo a distribuição de calor. As forças de corte podem ser reduzidas com ferramentas de geometria positiva para a aresta de corte e a distribuição de calor para a peça pode diminuir com uma maior velocidade de corte (KLOCKE e EISENBLAETTER, 1997).

A definição de mínima quantidade de fluido (MQF) é o emprego de quantidades pequenas de fluido de corte, com vazão da ordem de unidades de $\mathrm{ml} / \mathrm{h}$, sendo a aplicação de fluido convencional 1/min, ou seja, cerca de 60.000 vezes maior. O tema MQF é recente e artigos técnicos a respeito são limitados.

Como alternativa o MQF pode atenuar as desvantagens da aplicação por inundação proporcionando benefícios não disponíveis na usinagem a seco. O MQF tem como vantagens: a redução do emprego de fluidos para trabalhar metais, resultando em 
menores custos, melhor higiene industrial, a oportunidade de emprego de fluidos não agressivos (ex. óleos vegetais) e melhor desempenho comparado à usinagem a seco. A disseminação do MQF ainda depende da explicitação de custos, problemas relativos à remoção dos cavacos, potencial inflamável, partículas metálicas em suspensão e a confiabilidade e repetibilidade do sistema.

\subsection{Desenvolvimento do Processo de Corte e da Máquina Ferramenta}

As metas de produção tendem a aumentar a produtividade, flexibilidade e qualidade em mercados de competitividade global e produtos dedicados (lotes pequenos). As máquinas ferramentas são construídas para operações de corte de alto desempenho em altas velocidades, usinagem a seco e de materiais endurecidos, processos integrados, "usinagem completa" e novos materiais para ferramentas, buscando a redução significativa dos tempos produtivos e não produtivos. As inovações chave nas máquinas ferramentas são: eixos arvore de alta rotação e potência, sistemas de acionamento inovadores, guias lineares de esferas ou roletes, conceitos cinemáticos inovadores, materiais e construções leves, sensores e atuadores proporcionando estabilidade do processo, além de múltiplas tecnologias de fabricação integradas para redução de tempos e manipulação e transporte das peças a serem usinadas. Finalmente, minimização da poluição e consumo de energia é um desafio para o futuro.

\subsubsection{Processo Integrado e "Usinagem Completa"}

As cadeias clássicas de processos são inovadas buscando a execução da peça em apenas uma fixação à máquina, o que é usualmente chamado de "usinagem completa", alguns exemplos são:

- Integração de vários processos de usinagem em uma máquina ferramenta ( ex: torneamento, fresamento, furação, retificação, rebarbação );

- usinagem em seis faces;

- processos paralelos: dois ou mais processos acontecendo independentes na mesma máquina ( ex. torneamento em quatro eixos );

- processos híbridos: dois ou mais processos combinados para uma alteração específica da peça, também chamada usinagem assistida ( ex. torneamento assistido por laser );

- processos integrados: novos processos baseados em dois ou mais processos convencionais (ex. tratamento térmico e retificação); 
As abordagens citadas anteriormente como meta a redução dos tempos de processo que não agregam valor, redução de peças inacabadas na cadeia de processo e redução de várias fixações para operações diferentes, resultando em ganhos na qualidade dimensional da peça.

Os novos centros de usinagem possuem eixos árvore potentes com cabeçotes de alta velocidade montados nos eixos $\mathrm{X} / \mathrm{Y} / \mathrm{Z}$ e cem ou mais ferramentas carregadas por mecanismos de troca rápida automáticos.

Pela sua natureza modular e flexível o laser torna-se uma opção consistente para ser integrado às máquinas ferramenta. Os sistemas laser podem ser configurados para uma usinagem fina, furação, solda e tratamento superficial. O laser também pode auxiliar no corte de materiais de difícil usinagem como cerâmicas, super-ligas de Inconel, níquel, ligas de titânio e aços de alta dureza em centros de torneamento com laser $\mathrm{CO}_{2}$ ou $\mathrm{Nd}: Y A G$.

Uma forte tendência é melhorar a qualidade dimensional de processos de manufatura como conformação e fundição, conduzindo a menores volumes de corte. Novas tecnologias como sinterização a laser ou a substituição de metais por polímeros também favorecem a diminuição da usinagem que será empregada para a geração de superfícies de precisão ou ultraprecisão.

Os processos dedicados e operações de corte com grande flexibilidade, operações de “set-up" (preparação) e programação, troca de ferramenta, fixação e transporte da peça, são exigências de um mercado cada vez mais especializado atendendo a especificações individuais.

\subsubsection{Saúde e Segurança}

Usinagem em altas velocidades e grande desempenho requerem precauções relativas a muita energia cinética das peças e ferramentas. Vidros de segurança proteções reforçadas devem resistir a impactos em caso de acidentes. A usinagem a seco também exige soluções para o controle de e partículas e vapores gerados no processo. No desenvolvimento de novas máquinas, saúde e segurança são aspectos determinantes, assim como as relevantes normas de meio ambiente. É de se esperar que trabalhos 
futuros abordem consumo de energia e as necessidades emergentes dos novos processos híbridos ou integrados.

\subsubsection{Formação de Rebarbas}

A formação de rebarbas pode gerar alguns problemas, distorção dimensional, dificuldades de montagem, manipulação e deformação da sub-superfície associada à formação da rebarba. Os custos para a remoção das rebarbas são significativos. Para minimizar ou prevenir a formação de rebarbas, todos os estágios da manufatura devem estar integrados, o projeto, planejamento do processo e produção, para que as características da peça, restrições do material, seqüências de usinagem, processos e suas variáveis sejam consideradas sob a perspectiva da potencial criação de rebarbas na peça. Isto significa, as entradas (processo, material, ferramentas, geometria, fixação, etc.) devem ser consideradas junto com a funcionalidade da peça (desempenho, ajuste e montagem) assim como qualquer processo de rebarbação, planejado ou necessário, o que pode ter mais sucesso se padrões e classificações objetivas forem de fácil alcance. A qualidade das bordas pode ser especificada e a relação entre qualidade da borda e funcionalidade da peça facilmente entendida.

O desenvolvimento neste sentido pode seguir os seguintes elementos;

- modelos de previsão a partir de base de dados dedicada a especificação de processos;

- modelos de simulação da formação de rebarbas capazes de indicar a interação e dependências dos parâmetros de processo críticos (ex. modelos em elementos finitos); - estratégias para a redução de rebarbas, ligados aos programas de desenho (CAD) para o desenho de produtos e planejamento do processo;

- estratégias de inspeção para detectar e caracterizar rebarbas com sensores específicos para rebarbas;

As operações de fresamento têm sido o maior foco de prevenção a formação de rebarbas. Constatado que a cinemática da ferramenta, saindo da peça, é fator dominante para a formação de rebarbas, a trajetória da ferramenta sobre a peça tem sido ajustada com substancial sucesso. Os principais critérios para determinar trajetória da ferramenta são;

- evitar a saída dos insertos, ou seja sempre usinar sobre a aresta da peça; 
- estruturar as etapas do processo para que a rebarba seja na última aresta e a menos importante;

- controlar a seqüência da ordem de saída pela geometria da ferramenta e variação da trajetória;

- conservar a carga sobre as pastilhas uniforme em operações críticas;

- levantar a ferramenta ao executar manobras sobre a peça;

- evitar saídas empurrando, ou seja, longo contato da ferramenta com a borda;

Estes critérios são de difícil execução em todas as circunstancias, mas proporcionam vida mais longa à ferramenta e custos menores com operações de rebarbação, entretanto convém verificar as exigências de tempo de ciclo com as trajetórias redesenhadas.

\subsection{Desempenho da Usinagem}

Desempenho da usinagem, segundo Byrne; Dornfeld e Denkena (2003), é uma indicação do grau em que um conjunto de operações de produção está otimizado em relação a cada operação individualmente e também para o conjunto, assegurando que não haverá influência negativa de uma operação em outra. Isto com o propósito de diminuir a cadeia de agregar valor e a minimização das medições garantindo o controle de qualidade do processo.

Algumas medidas, usualmente associadas ao desempenho de usinagem, estão ilustradas na Figura 2.6.

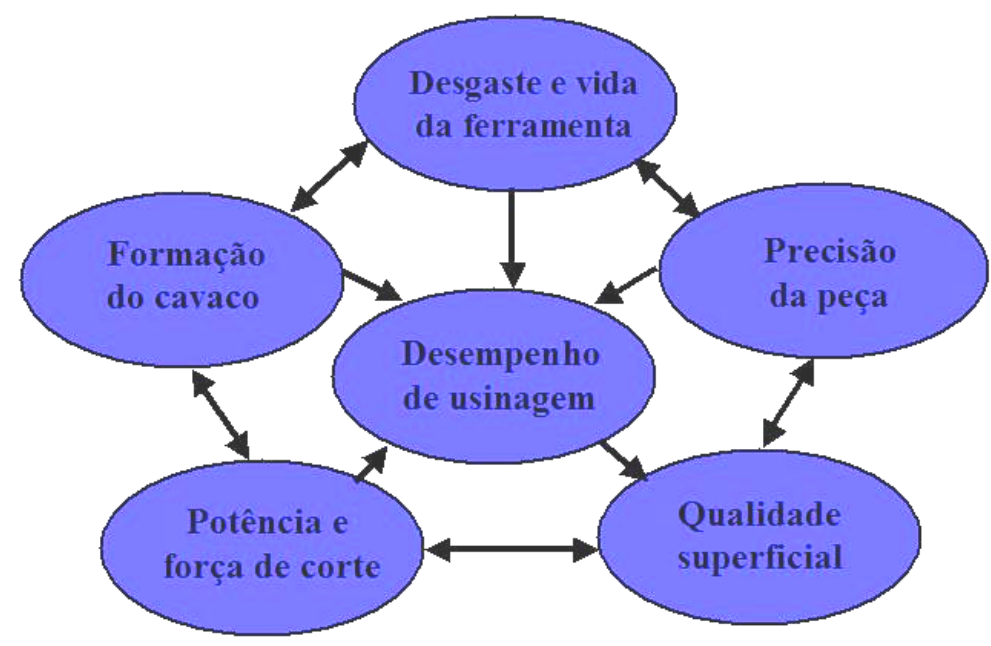

Figura 2.6 - Desempenho da usinagem. Fonte: Adaptado de Byrne; Dornfeld e Denkena (2003). 


\subsubsection{Previsão de Desempenho}

Como alternativa, para o estudo dos fenômenos de difícil observação, são construídos modelos teóricos através dos quais é possível verificar a influência dos vários parâmetros do processo.

Hoje são comuns os modelos com técnicas eulerianas ou lagrangianas em elementos finitos. Abaixo são relacionadas quatro categorias de modelagem:

- Modelagem analítica: Byrne; Dornfeld e Denkena (2003) citam o trabalho de Ernst e Merchant de 1941, determinação da relação entre as forças de corte e a geometria da ferramenta, determinação experimental do ângulo de cisalhamento, condições de atrito e escoamento do cavaco.

- Modelagem das linhas de escorregamento: Byrne; Dornfeld e Denkena (2003) citam o trabalho de Oxley de 1959 que prevê a resposta mecânica e distribuição de temperaturas baseado em considerações sobre o campo das linhas de escorregamento na geometria da zona de cisalhamento.

- Modelagem mecânica: Byrne; Dornfeld e Denkena (2003) citam o trabalho de Tlusty de 1988 que prevê as forças de corte para uma ampla gama de processos de usinagem complexos, assumindo que as forças de corte são produto da área do cavaco antes do corte e a energia específica de corte sendo esta empiricamente derivada do material da peça, parâmetros de corte e geometria de corte.

- Modelagem em elementos finitos (técnica que emprega representações em uma malha, do material e da ferramenta como base para determinar tensões no material e condições características, e ultimamente, o fluxo de material assumindo a continuidade de elementos adjacentes).

A aplicação destas técnicas de modelagem abrange os aspectos interessantes aos processos de usinagem, como forças de corte (estática e dinâmica), potência, desgaste e vida da ferramenta, comportamento do cavaco (ângulo/curva/forma), aresta postiça de corte, temperaturas, condições e integridade superficial da peça, geometria da ferramenta, recobrimento e influência do seu desenho, formação de rebarbas, distorção de medidas e precisão da peça, limites de estabilidade dinâmicos e danos térmicos, 
assim como os processos de corte ortogonal, fresamento multi-dentes, torneamento de materiais endurecidos e furação. Áreas como usinagem de materiais endurecidos, formação de rebarbas e também dos cavacos, temperatura e desgaste da ferramenta no corte, apresentaram ganhos significativos ao desempenho através da modelagem.

\subsubsection{Simulação Baseada na Dinâmica Molecular}

A nova classe de modelagem, chamada dinâmica molecular, está no nível nanométrico, ou seja, superfícies bem menores que as abordadas nas técnicas convencionais como método de elementos finitos. A teoria da dinâmica molecular é baseada na física, compreendendo interações atômicas e, portanto o comportamento dos materiais neste nível. Torna-se possível estudar a geração de uma superfície e o desenvolvimento da rugosidade e também analisar a sub-superfície da área de corte. Efeitos como formação de deslocamento e alívio de tensões podem ser simulados e observados em duas dimensões ou na configuração de usinagem em três dimensões.

\subsubsection{Novas Direções no Incremento da Compreensão do Processo}

O incremento na capacidade de modelagem dos processos em escala macro e nano reforça o desenvolvimento da simulação de processos com melhor entendimento dos mesmos. A direção dos avanços deve ser:

- transição de duas dimensões para a capacidade três dimensões de processos reais;

- aumentar a facilidade de mudança de parâmetros de ferramentas (geometria, recobrimento/atrito, propriedades do material, características mecânicas);

- propriedades do material (para inserção no modelo ) aprimoradas;

- acomodação de múltiplos materiais/camadas;

- maior complexidade nos desenhos das peças;

- resolução no nível das variáveis em micro ou nano-escala (grãos, inclusões, etc).

- capacidade de simulação mais real dos elementos de processo (cavaco, rebarba, tensões residuais, distorções de forma).

Desafios:

- como integrar em sistemas CAD as funções de projeto de produto e processo;

- a validação dos modelos;

- aprimorar base de dados de propriedades dos materiais;

- aprimorar a interface para o usuário (facilidade de implementação). 
Áreas com potencial de aprimoramento: torneamento de materiais endurecidos, usinagem a seco, usinagem com altas velocidades de corte, formação e minimização de rebarbas, formação do cavaco e seu controle, e a simulação de todo o processo visando tempos não produtivos reduzidos.

\subsubsection{Monitoramento das Operações de Corte}

A complexa interação entre máquinas, ferramentas, peças, fluidos, sistemas de medição, sistemas manipuladores de material, requerem o emprego de sensores para assegurar eficiência de produção, indicar necessidade de manutenção, protegendo trabalhadores e meio ambiente.

Existem sistemas de monitoramento de desgaste e quebra da ferramenta. A tendência de aumentar a flexibilidade dos sistemas requer desenvolvimento de sensores, interfaces e controladores de máquinas (controle adaptativo de arquitetura aberta e sistemas reconfiguráveis).

Para alcançar a "máquina ferramenta inteligente", capaz de executar a usinagem com desempenho otimizado, são necessários sensores com sistemas de controle capazes de acumular a experiência adquirida empregando a em situações futuras.

Parece uma solução óbvia o emprego de sistemas dinâmicos para a supervisão de um processo dinâmico como a usinagem, mas provavelmente por problemas de estabilidade, a resposta de uma rede puramente dinâmica é limitada. Uma abordagem promissora é o modelo no qual as redes estática e dinâmica são combinadas hierarquicamente com uma representação do processo de usinagem tipo "estado espaço".

\section{Sensores integrados}

Sistemas de sensores integrados podem realizar várias tarefas contribuindo para a otimização do processo. O desempenho geral da usinagem requer a redução dos tempos não produtivos, verificação e manutenção da capacidade do processo, proporcionando reduções de custos diretos e garantindo a produção amigável ao meio ambiente. 


\section{Avaliação integrada da qualidade da peça}

Definir a qualidade da peça quantitativamente em uma gama de processos e peças usinadas (exemplo: dano na sub-superfície ou rugosidade superficial). Medir ou acessar de alguma forma os elementos de qualidade da peça como parte do ambiente de produção (exemplo: a rugosidade superficial que é gerada por muitas variáveis independentes no processo). Este é um objetivo a ser atingido com vários desafios a serem superados, entre eles, ainda não se equacionou como incorporar a informação dentro dos esquemas de controle da máquina e do processo.

\subsection{Sustentabilidade na Indústria}

Em seu artigo Sustentabilidade Global - Um Cenário Futuro, Seliger (2004) discute a importância dos problemas sociais do planeta, como a educação deve ter papel fundamental neste contexto e as oportunidades geradas para a engenharia na transição de uma economia de produtos para serviços, com o compromisso de preservar recursos, em direção à desmaterialização da economia integrada do planeta.

\subsubsection{Análise de Ciclo de Vida}

Magnani (2000) ressalta a importância da "análise de ciclo de vida" (ACV) abaixo definida:

“ACV é um processo objetivo para avaliar os impactos ambientais associados a um produto, processo ou atividade mediante a identificação e quantificação do consumo de materiais e energia e das emissões no meio ambiente, e para identificar e avaliar as alternativas que supõe melhora ambiental. Essa análise cobre todo o ciclo de vida do produto, processo ou atividade a partir da extração e processamento da matéria-prima, a fabricação, o transporte e a distribuição, a utilização, a reutilização, a manutenção e a reciclagem, até a disposição final do mesmo".

Através do emprego desta ferramenta é possível dar suporte ao processo de tomada de decisão visando adotar soluções adequadas ao meio ambiente. Com grande expectativa por parte da industria, uma das maiores restrições para disseminar seu uso e um banco de dados para a elaboração do estudo de impactos. 


\subsubsection{Normas, Certificações e Produção Mais Limpa}

A mais conhecida direção para implementar a relação da indústria com as questões ambientais é a certificação dos "sistemas de gestão ambiental” (SGA) regulamentada no Brasil pela norma NBR ISO 14.001. A normalização dos sistemas de gestão, interessante às questões ambientais, não é suficiente considerada a necessidade da mudança dos paradigmas de produção.

Lançada pelo PNUMA em 1989, a produção mais limpa (P+L) é reconhecida como ferramenta para o desenvolvimento sustentável. Existe uma rede global de mais de 300 organizações dedicadas à difusão e implementação de técnicas de $\mathrm{P}+\mathrm{L}$, entre eles a Mesa Redonda Paulista de P+L e o Centro SENAI de Produção Mais Limpa (CPC). As técnicas $\mathrm{P}+\mathrm{L}$ são especialmente interessantes, pois podem ser aplicadas isoladamente a cada processo ou serviço, possibilitando à empresa a adequação ambiental progressivamente e de maneira simplificada podendo convergir para a certificação (SANTOS, 2005). Sua definição é simples:

“A aplicação contínua de uma estratégia ambiental integrada e preventiva a processos, produtos e serviços, com a finalidade de aumentar a eficiência e reduzir riscos aos seres humanos e ao meio ambiente."

Para aplicar os princípios da "Produção Mais Limpa" UNITED NATIONS ENVIRONMENT PROGRAM INDUSTRY AND ENVIRONMENT - UNEP IE (1996) relaciona cinco aspectos do processo: a tecnologia, a execução do processo, matérias primas e insumos, o produto e a última, resíduos e emissões. Na abordagem do processo são sugeridos os pontos de ação para a aplicação das técnicas relacionadas: a mudança tecnológica , a alteração do produto, as boas práticas "housekeeping", a mudança nos insumos do processo e a reutilização e reciclagem interna para a empresa.

\subsubsection{Sustentabilidade na Usinagem}

Trent (1996) avalia que, uma parte significativa de todo o metal produzido torna-se cavaco. Para reduzir as perdas sugere que processos como forjamento, fundição de precisão e metalurgia do pó devem ser aprimorados. 
Apesar das perdas a usinagem ainda é uma das alternativas mais acessíveis para produzir diversas formas nas peças metálicas. A evolução das tecnologias proporcionando padrões de usinagem elevados com alta eficiência, precisão e com a redução significativa das condições de trabalho intoleráveis é de grande importância para a indústria (TRENT, 1996).

Queiroz; Boehs e Sant'Anna (1999) propõe que através de um sistema de gestão dos fluidos de corte ocorra a diminuição efetiva dos impactos ambientais a eles relacionados, e ainda a diminuição de fluido de corte utilizado, a conseqüente redução de volume para a manutenção, custos menores de tratamento, disposição final, aumento da reutilização e reciclagem dos fluidos utilizados.

Wanigarathne et al. (2004) enfatizam a complexidade das questões ligadas à sustentabilidade, afirmando que ela só poderá ser atingida através do esforço coletivo e unificado da comunidade global em uma abordagem multi-disciplinar.Dividida em três áreas principais: meio ambiente, sociedade e economia, com interações fortes e de difícil compreensão, é significativa a trajetória de entendimento em uma atividade que compõe o sistema. Propondo um método científico visando a "Avaliação da Sustentabilidade do Processo de Manufatura do Produto em Operações de Usinagem" os autores buscam a manufatura sustentável como contribuição para a sustentabilidade econômica, facilitando o crescimento sustentado como base para o "desenvolvimento sustentável".

Com poucos avanços na quantificação da sustentabilidade dos processos de usinagem, é de grande importância ter o controle dos riscos à saúde e os impactos ambientais associados ao emprego de fluidos de corte, a minimização da produção de resíduos e ou substancias tóxicas na operação de corte e a otimização da energia consumida, que deve ser procedente de fonte não poluente.

Com o auxílio de um índice de "sustentabilidade da usinagem" seria possível avaliar e propor o planejamento de longo prazo e também implantar o conceito em outros processos de fabricação, convergindo para a discussão da comunidade industrial e autoridades responsáveis, dos caminhos e medidas para favorecer a sustentabilidade nos processos. 
O método proposto por Wanigarathne et al. (2004) é amigável ao usuário e privilegia a comunicação eficiente, em um diagrama de fácil interpretação onde são representados os seis principais parâmetros medidos (mais parâmetros podem ser incluídos), adotados com base em observações, dados empíricos e estatísticos. Os indicadores, saúde do trabalhador, amigável ao meio ambiente, consumo de energia, redução de resíduos, segurança operacional e custos de usinagem, recebem tamanhos diferentes compondo a figura onde pode ser visualizada facilmente a situação do processo analisado. Conforme ilustrado pela Figura 2.7.

\section{Avaliação da Sustentabilidade na Usinagem}

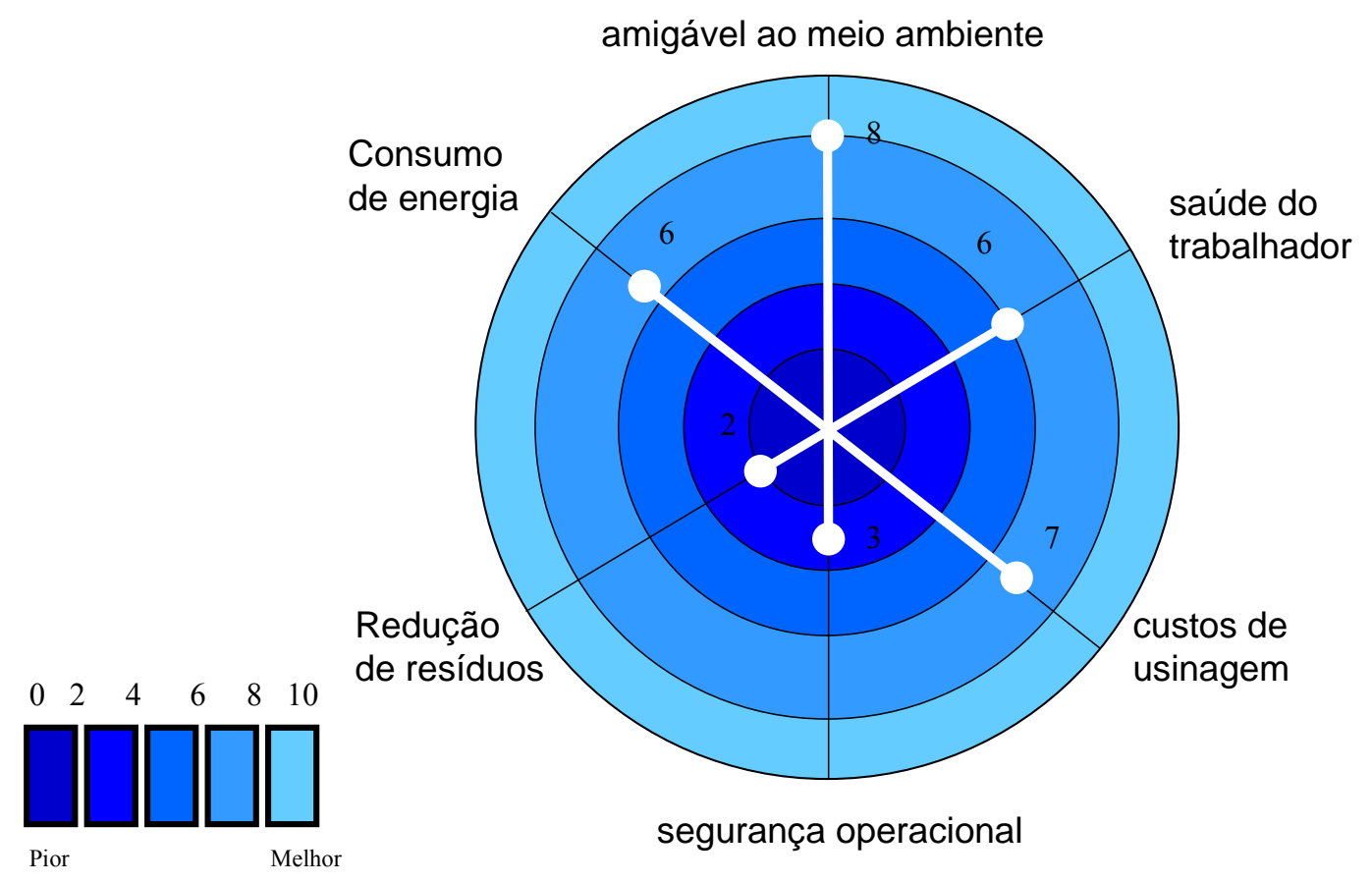

Figura 2.7 - Exemplo de avaliação da sustentabilidade na usinagem.

Fonte: Adaptado de Wanigarathne et al. (2004).

Para estabelecer o índice de sustentabilidade os parâmetros recebem tratamento científico fundamentado nos princípios de sustentabilidade para o projeto e fabricação do produto, usando método de modelagem e otimização, em abordagem abrangente da usinagem segundo descrito no fluxograma da Figura 2.8. 


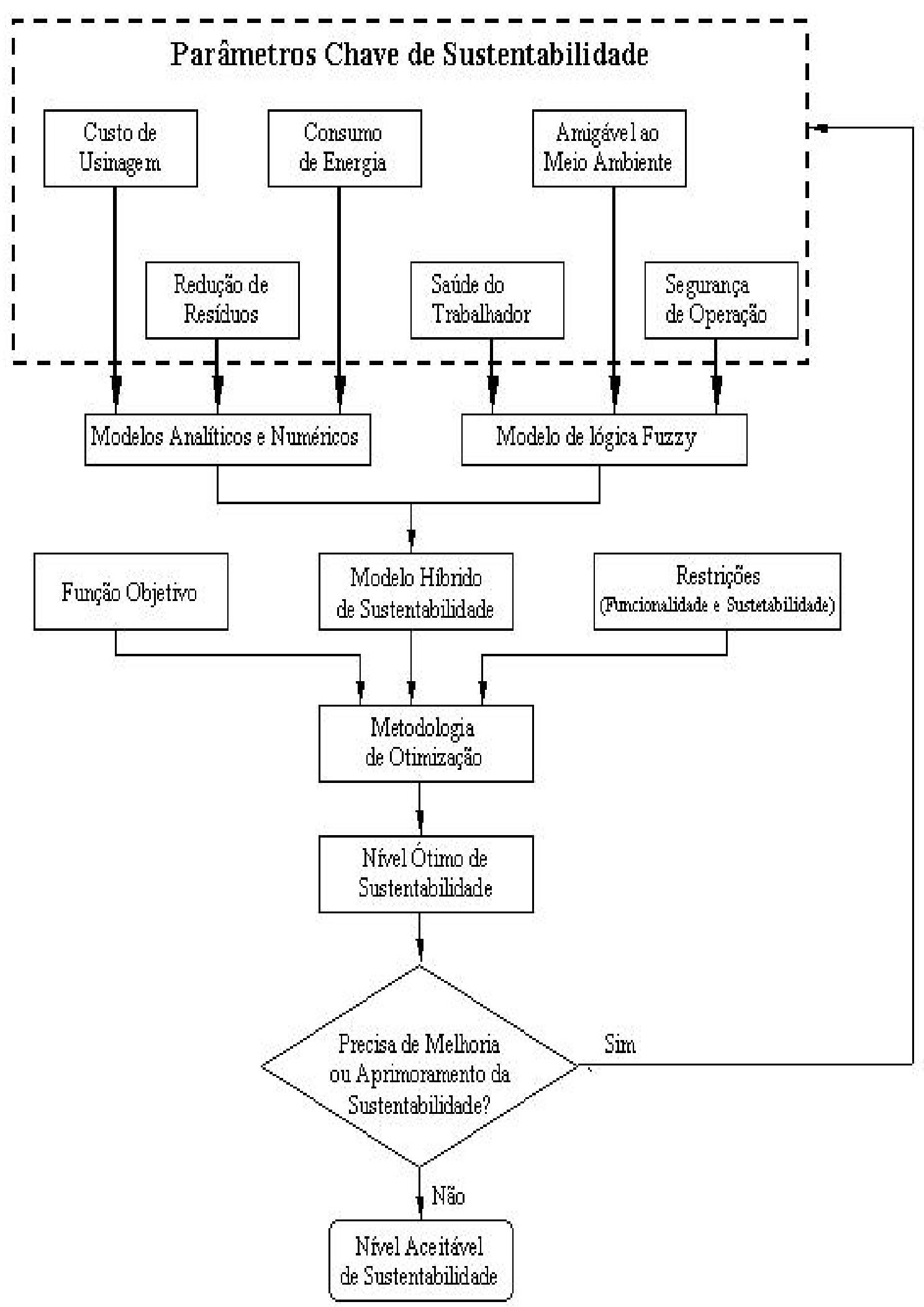

Figura 2.8 - Fluxograma do modelo preditivo proposto e método de otimização para a sustentabilidade da usinagem.

Fonte: Adaptado de Wanigarathne et al. (2004). 


\subsubsection{Diretrizes Para a Sustentabilidade}

As diretrizes para a sustentabilidade organizadas a partir das contribuições de diferentes pesquisadores são apresentadas a seguir:

- A função social de uma empresa é gerar produtos e serviços que revertam em bem estar para a sociedade (MANZINI e VEZZOLI, 2002).

- A clareza do foco do negócio e capacidade de agregar valor aos insumos de produção é fundamental para otimizar os recursos empregados no processo (ROTHER e SHOOK, 1999 ).

- Os processos devem ser totalmente controlados e rastreáveis em todas as suas etapas, proporcionando uma visão sólida e abrangente da seqüência de transformações. Desta forma torna-se fácil, a ação pontual e o aprimoramento contínuo (SCHONBERGER, 1984).

- Cada processo deve ser interpretado como um sistema, buscando a minimização de recursos consumidos, com a alimentação deste sistema rigorosamente monitorada (BYRNE e SCHOLTA 1993).

- Durante a execução do processo a transparência facilita o controle de produtos e resíduos que merecem o mesmo rigor no cumprimento de padrões estipulados.

- Os produtos e resíduos devem ter intensidade material cada vez menor qualidade uniforme e não possuir substâncias perigosas à saúde humana ou ao meio ambiente. - Sempre que possível os resíduos devem ser reutilizáveis ou recicláveis, esgotadas as possibilidades devem ser tratados e dispostos adequadamente.

- Acompanhar de forma criteriosa todo o ciclo dos resíduos, da geração a disposição final, empregando as técnicas e tecnologias mais compatíveis com a realidade local (LEITE, 1997).

- Circunstancias envolvendo elementos tóxicos devem ser tratadas como extraordinárias, e nada deve deixar o sistema sem as devidas medidas de segurança. - Os subprodutos do processo (resíduos) não podem dispersar-se no ambiente fabril, devem ser segregados, caracterizados, tratados e destinados a novos processos, em uma cadeia de produção fechada, que consome do meio apenas o que este pode suprir de forma contínua sem impactos ou perda de qualidade. 
Adicionalmente, os autores Graedel e Allenby (1995) em seu livro "Ecologia Industrial" apresentam os objetivos e princípios abaixo relacionados:

- Cada molécula que entra no processo deve sair como parte de um produto desejado e com valor comercial.

- Cada unidade de energia empregada no processo deve produzir a transformação material desejada.

- A indústria deve empregar o mínimo de matéria e energia em produtos, processos e serviços.

- A indústria deve optar por materiais não tóxicos e abundantes ao conceber seus produtos.

- A maior parte dos materiais deve ser proveniente de cadeias de reciclagem.

- Todo processo e produto deve ser concebido para preservar a características dos materiais empregados, planejando também a possibilidade de remanufatura e modularidade.

- Todo produto deve ser concebido para que tenha emprego útil ao fim da vida.

- Toda instalação deve ser desenvolvida construída ou modificada buscando melhorar habitats locais e biodiversidade.

- Interação dos fornecedores, clientes e outras indústrias, desenvolvendo cooperação (ex. minimizar embalagens, reciclar e reutilizar materiais.

Os autores enfatizam a importância das empresas na transição para uma economia no contexto do desenvolvimento sustentável enumerando os principais aspectos aos quais devem se adaptar.

1. A empresa privada, como especialista em sua tecnologia, deve tornar-se parceira no desenvolvimento de novas estruturas reguladoras. Isto exigirá das empresas desenvolver posicionamentos aceitáveis a todas as partes interessadas da sociedade (stakeholders), inclusive os ambientalistas e organismos reguladores, substituindo posturas negativas do passado.

2. Novas organizações e fluxos de informação devem ser desenvolvidos com a incorporação dos aspectos ambientais, em novos posicionamentos integrando o meio ambiente e a tecnologia de maneira responsável. 
3. As empresas devem lançar esforços para desenvolver e implementar sistemas contábeis em que os custos ambientais sejam automaticamente incorporados às decisões econômicas.

4. As empresas devem enxergar a sociedade como um todo, e a comunidade em que opera, como parceira de suas atividades. As comunidades (em seu sentido mais amplo) devem ser vistas como clientes de seus serviços ao invés de apenas compradores de seus produtos. Os aspectos ambientais impulsionarão o papel das empresas em direção a uma função social mais ampla. 


\section{MATERIAIS E MÉTODOS}

O desenvolvimento de uma abordagem para a interação com a PME pretende captar as necessidades e carências tecnológicas nos processos de usinagem, disseminar o conhecimento e transferir tecnologia.

A proposta é conduzir ao melhor desempenho da indústria, torná-la mais competitiva, reforçando seu papel de gerar produtos e serviços que sejam revertidos em bem estar social.

A discussão dos conceitos que fundamentam o trabalho de campo conduz à interpretação de cada processo como o sistema representado na Figura 3.1.

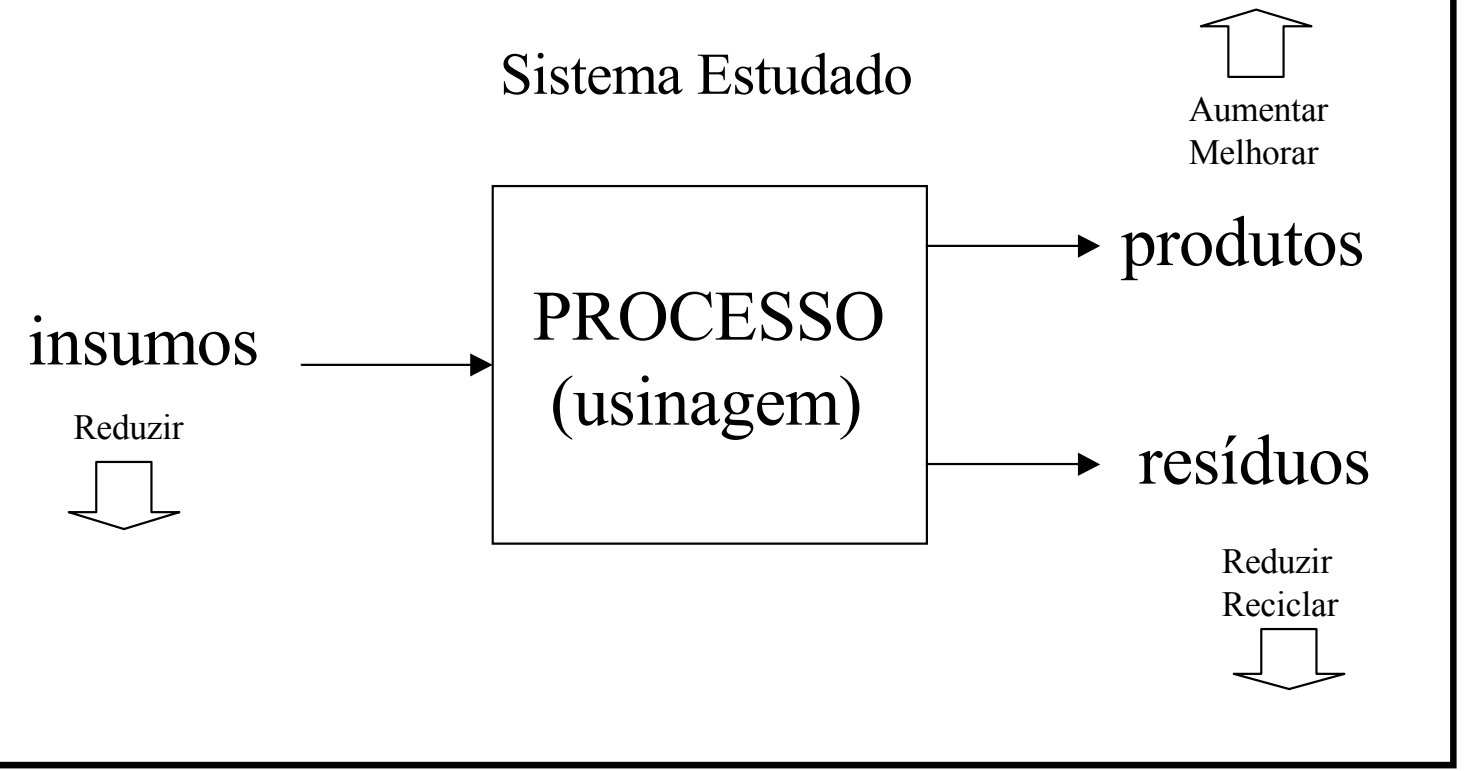

Figura 3.1 - Sistema adotado para análise do processo com as metas de otimização. 
O processo de torneamento, estudado no âmbito deste trabalho, deve ser monitorado como um sistema com as suas entradas e saídas controladas.

Orientados para a mudança do paradigma de produção, os experimentos registrados tem o objetivo de reduzir significativamente o consumo de insumos (matéria e energia) e produzir maior volume, com melhor qualidade em menor tempo. Os resíduos não podem gerar impactos ambientais e minimizados devem ser dirigidos a uma nova cadeia de produção onde serão empregados como insumos (reciclagem).

Com a proposta de promover a discussão de novos conceitos, visando orientar para as direções futuras no universo da fabricação mecânica, são implementadas tecnologias acessíveis ao pequeno empreendedor, junto ao conhecimento exigido para o processo.

O método proposto adota como objeto de estudo o parque industrial, que é pesquisado para a composição de um cenário. Com o panorama da situação é possível selecionar uma empresa e dentro dela um processo que deve receber uma intervenção. A partir dos resultados obtidos é possível aferir os conceitos, o método proposto e viabilizar a implementação de seus benefícios em novos processos e diferentes empresas.

Para o desenvolvimento dos trabalhos e sua fácil reprodução são elaboradas diretrizes denominadas "Diretrizes Para o Trabalho de Campo" e um "Roteiro de Atividades". O roteiro apresentado a seguir orienta a descrição das atividades realizadas com a função de guia, oferecendo também a estrutura deste capítulo.

\section{Roteiro de Atividades}

- Selecionar o grupo amostral.

- Obter informações, organizar e construir o cenário.

- Verificar oportunidades de intervenções em ações pontuais.

- Eleger o processo que receberá as intervenções.

- Planejar os experimentos.

- Executar os experimentos.

- Organizar dados e avaliar resultados. 
As diretrizes para o trabalho de campo estão abaixo relacionadas:

\section{Diretrizes Para o Trabalho de Campo}

- As empresas envolvidas serão preservadas através da identificação por códigos e as informações de uso restrito a este estudo.

- Os dados obtidos são organizados e discutidos por uma equipe de pesquisadores do laboratório OPF, para oferecer consistência e confiabilidade aos trabalhos.

- O envolvimento da direção da empresa amplia as chances de sucesso. Ela deve apresentar os pontos críticos e aspectos importantes na produção, elegendo alguns dos processos como potenciais elementos de estudo.

- As intervenções devem abordar aspectos de interesse da empresa e desenvolvidas respeitando prioridades e o planejamento de produção.

- A intervenção nos processos deve ser uma forma de inserir uma nova abordagem. Para o início da transformação são necessários, flexibilidade, respeito a limites e valorização das contribuições de todos os envolvidos nas atividades.

- A meta da intervenção é obter resultados significativos em ações pontuais, com potencial de serem repetidos em novos processos, estendendo o seu efeito na empresa ou no parque industrial.

- Para ressaltar o impacto dos ganhos, é interessante abordar um processo onde a escala de produção proporcione resultados de expressão seja em valores econômicos, ambientais e ou sociais.

\subsection{Selecionar o Grupo Amostral}

Estabelecido o universo do estudo como, o conjunto das micro, pequenas e médias empresas (PME's), com processos de fabricação empregando a usinagem convencional, no município de São Carlos, identificam-se dezoito empresas nas condições delimitadas, dentro do conjunto de noventa e quatro associadas a CIESP (Centro das Indústrias do Estado de São Paulo). Nesta etapa é possível envolver no estudo seis empresas com disposição em interagir e competências orientadas aos interesses do estudo. 


\subsection{Obter Informações e Construir Cenário}

Ao conhecer o corpo técnico e a área de fabricação é possível verificar o potencial de cada empresa, para interação no estudo. Na coleta de informações inicial constam dados gerais da empresa como, ramo, porte e segmento de mercado, os dados específicos são organizados em quatro grupos: materiais e operações, máquinas e processos, ferramentas de corte e auxiliares de processo (fluidos de corte). O questionário aplicado e as respostas podem ser encontrados no Apêndice A, cabe observar que o representante da empresa, independente do cargo que ocupa é quem responde as perguntas. Com a organização da informação é possível a construção de um cenário, base para o roteiro de ação.

\subsection{Verificar Oportunidades de Intervenções em Ações Pontuais}

O cenário construído permite visualizar a situação em estudo e as possibilidades de interagir com as respectivas empresas, selecionando aquela, onde ações pontuais sejam revertidas em ganhos mensuráveis.

Esta empresa recebe visitas de observação dos processos de usinagem, verificando as possibilidades para melhorar o desempenho com uma injeção de conhecimento ou o emprego de tecnologia.

Após duas visitas para acompanhar a produção, na discussão com os pesquisadores da equipe OPF, conclui-se que os processos analisados comportariam melhoramentos. No entanto a usinagem não está no foco de negócios da empresa em estudo, sendo área de suporte, e a produção, em lotes pequenos e ciclos espaçados proporciona pouca visibilidade aos potenciais ganhos.

Portanto a opção seguinte é ampliar o grupo amostral. Com o auxílio de profissionais ligados à usinagem, são selecionadas cinco empresas que não pertencem ao primeiro grupo (associadas à CIESP) ampliando para onze o número de empresas envolvidas no estudo. Repetido o procedimento padrão, o cenário construído com as novas informações, ganha em diversidade. 


\subsection{Eleger o Processo que Receberá as Intervenções}

Uma empresa de usinagem, onde os lotes de produção são milhares de unidades e contando com o envolvimento da direção passa a ser o foco do estudo. As visitas de observação evidenciam potencial de ganhos em processo de torneamento nas máquinas com comando numérico computadorizado (CNC).

Neste primeiro contato são verificadas duas oportunidades de ganhos para o desempenho do processo.

Com demonstrações da importância de utilizar toda a gama de rotações da máquina é possível a usinagem com velocidades de corte $\left(\mathrm{v}_{\mathrm{c}}\right)$ maiores e ao ativar o comando de velocidade de corte constante, as condições de formação do cavaco são melhoradas, resultando em melhores condições para a ferramenta e qualidade da superfície produzida.

Ao selecionar o que deve ser estudado, conclui-se, em conjunto com o corpo técnico da empresa, que a redução do tempo de usinagem, explorando os parâmetros de corte e ou o emprego de ferramentas mais adequadas, é uma abordagem interessante, pois proporciona simultaneamente um aumento de capacidade e a discussão dos conceitos do corte de metais e desempenho das ferramentas.

Neste estágio são avaliadas as alternativas, elegendo o foco da intervenção. $O$ torneamento de uma superfície de acoplamento cilíndrica é eleito o objeto de estudo.

O diâmetro limitado por tolerância de $0,05 \mathrm{~mm}$ (cinco centésimos de milímetro) é considerado superfície crítica, de produção lenta, sujeita a variações, exigindo verificações e ajustes constantes.

O material da peça, aço ABNT 1020, oferece dificuldades ao controle da uniformidade na qualidade superficial e formação do cavaco. O processo torna-se especialmente interessante por seu histórico de produção anual de cem mil peças. A Figura 3.2 apresenta os detalhes da peça. 


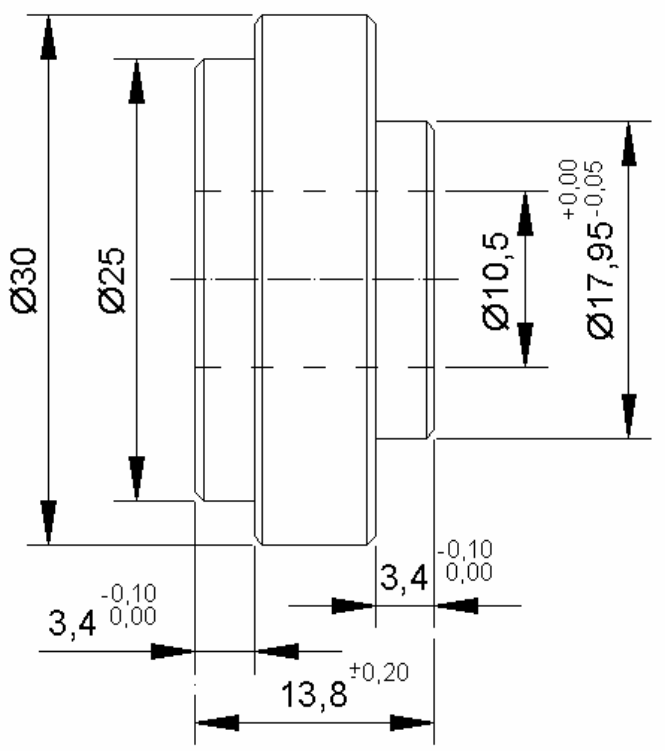

a) Desenho com dimensões.

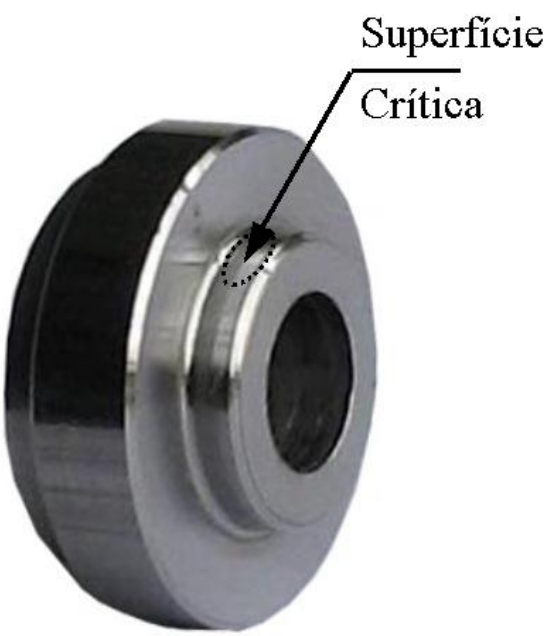

b) Fotografia da peça.

Figura 3.2 - Detalhes da peça em estudo.

A Figura 3.2 a apresenta a vista lateral da peça com suas dimensões e tolerâncias onde pode ser vista a especificação do diâmetro 17,95 mm objeto de estudo. A Figura 3.2 b é uma fotografia da peça onde está indicada a superfície cilíndrica de diâmetro 17,95 mm, denominada "Superfície Crítica".

\subsection{Planejar os Experimentos}

A intervenção é a oportunidade praticar os conceitos do novo paradigma de produção no processo de usinagem. Utilizando fundamentos das técnicas de "Produção Mais Limpa" o sistema estudado deve ganhar eficiência e controle, com melhor desempenho nos aspectos econômicos, sociais e ambientais. Com o intuito de ampliar o efeito da ação são realizados experimentos atacando três focos distintos, a tecnologia de usinagem, a economia de recursos e a cadeia de resíduos.

Os dois primeiros são realizados na empresa como ensaios de usinagem, avaliando os tópicos, redução do tempo de ciclo de produção da peça, estudo da influência da variação dos parâmetros de corte, vida da aresta (tempo de corte) e observação de desempenho do equipamento. As datas dos ensaios são organizadas pela empresa, respeitando o planejamento da produção e a disponibilidade de pessoal e do torno utilizado. A equipe OPF participa da elaboração da folha de processo, que determina a 
atuação das ferramentas, sendo o programa CNC desenvolvido pelo operador da máquina, ambos podem ser analisados no Apêndice B.

O terceiro foco experimental, com a proposta de regularizar a cadeia de resíduos, é o tratamento e caracterização do fluido de corte na fase de descarte, sendo executado no Laboratório de Resíduos Químicos, que serve o campus da Universidade de São Paulo em São Carlos, sob orientação do especialista em tratamento de efluentes do fabricante do fluido de corte.

\subsubsection{Tecnologia de Usinagem e Otimização do Processo.}

Este foco experimental conduz ao desenvolvimento dos conhecimentos para a usinagem da superfície crítica estudada. A análise da classe, geometria e cobertura da ferramenta é pré-requisito da decisão ótima. Com a contribuição da assistência técnica do fabricante é adotado um inserto para facear (triangular com aresta aguda) que deve executar o desbaste em apenas um passe, buscando a redução do tempo de corte e confiabilidade para a operação. Para o acabamento a opção é o inserto trigonal do tipo "Wiper". A Figura 3.3 ilustra a configuração do inserto triangular em operação.

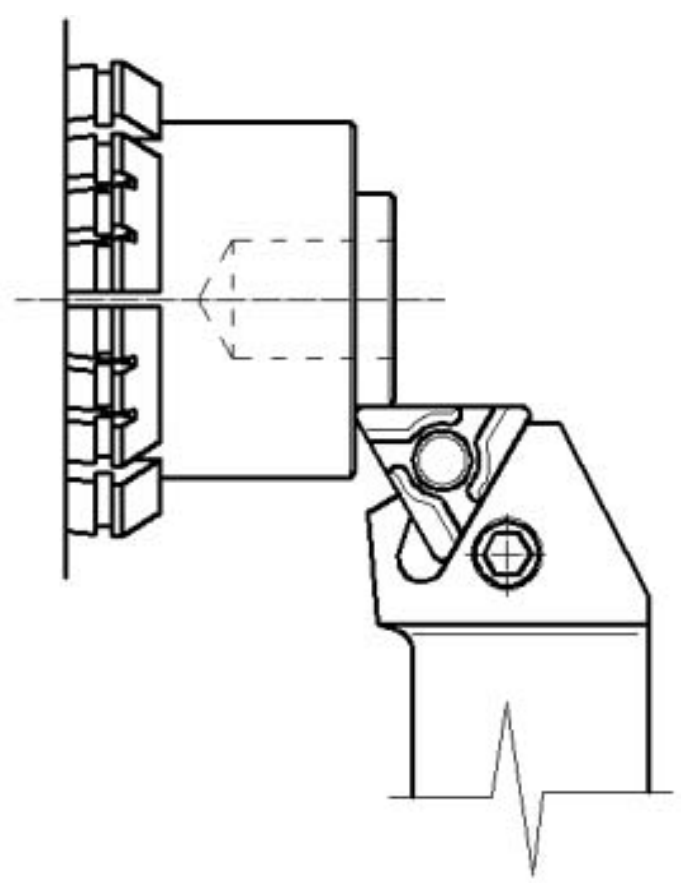

Figura 3.3 - Configuração para desbaste em passe único. 


\subsubsection{Economia de Recursos}

Ao cortar a peça, a largura do inserto de corte " $\mathrm{l}_{\mathrm{a}}$ " determina a quantidade de material perdido nesta operação. Com a redução de três para dois milímetros, é possível diminuir a perda no corte em 33\% e o consumo de aço em 6\% (matéria prima), proporcionando ganhos econômicos e ambientais.

Através do experimento verifica-se a capacidade da ferramenta de suportar as condições de corte da peça e operações de torneamento. A sua viabilidade econômica é determinada pela vida da aresta de corte. A transição deverá ser progressiva, os primeiros testes são executados com um inserto de largura " $\mathrm{a}_{\mathrm{a}}$ " dois milímetros e meio, a obtenção de resultados satisfatórios conduz a avaliação de desempenho do inserto de dois milímetros. A Figura 3.4 ilustra a configuração do inserto de corte com largura " $\mathrm{l}_{\mathrm{a}}$ " que é equivalente à profundidade de corte " $\mathrm{a}_{\mathrm{p}}$ ".

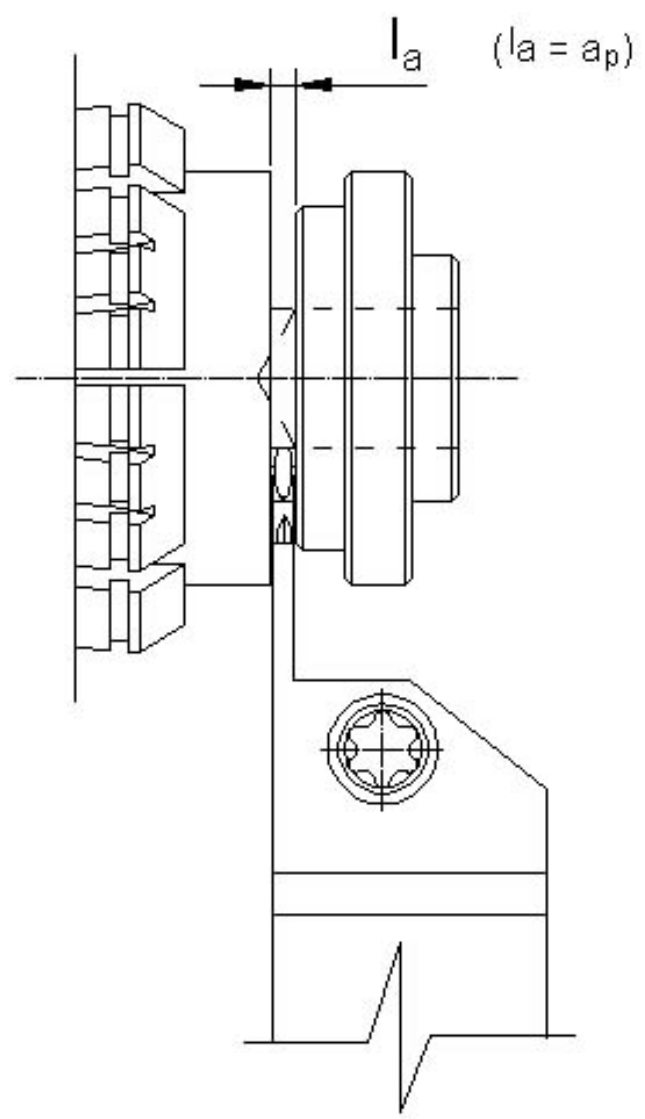

Figura 3.4 - Configuração do inserto de corte com largura " $l_{\mathrm{a}}$ ". 


\subsubsection{Cadeia de Resíduos}

O problema identificado na análise do cenário, de que o descarte do fluido de corte é problema comum às empresas, torna relevante o seu equacionamento, buscando $\mathrm{o}$ equilíbrio das entradas e saídas do sistema.

O tratamento é viabilizado através de parceria com o fabricante que oferece o conhecimento e a garantia de não existirem, no material tratado, substâncias determinadas como tóxicas pelas agências reguladoras.

Os experimentos são realizados em escala laboratorial, e tem como objetivos, registrar os procedimentos, avaliar viabilidades e caracterizar os resíduos.

O fluido de corte adotado para os ensaios é do tipo sintético. O composto a base de "polialquileno glicol” (PAG), oferece excelente refrigeração e boa lubrificação nas operações de corte, baixa toxicidade para o operador, é reciclável e seu tratamento não oferece dificuldades.

Com o tempo de operação de um mês, o fluido é submetido a tratamento físico-químico, que separa a solução em água, numa proporção maior que $95 \%$, e o resíduo sólido. A Figura 3.5 mostra o fluido em operação e os resíduos após o tratamento.
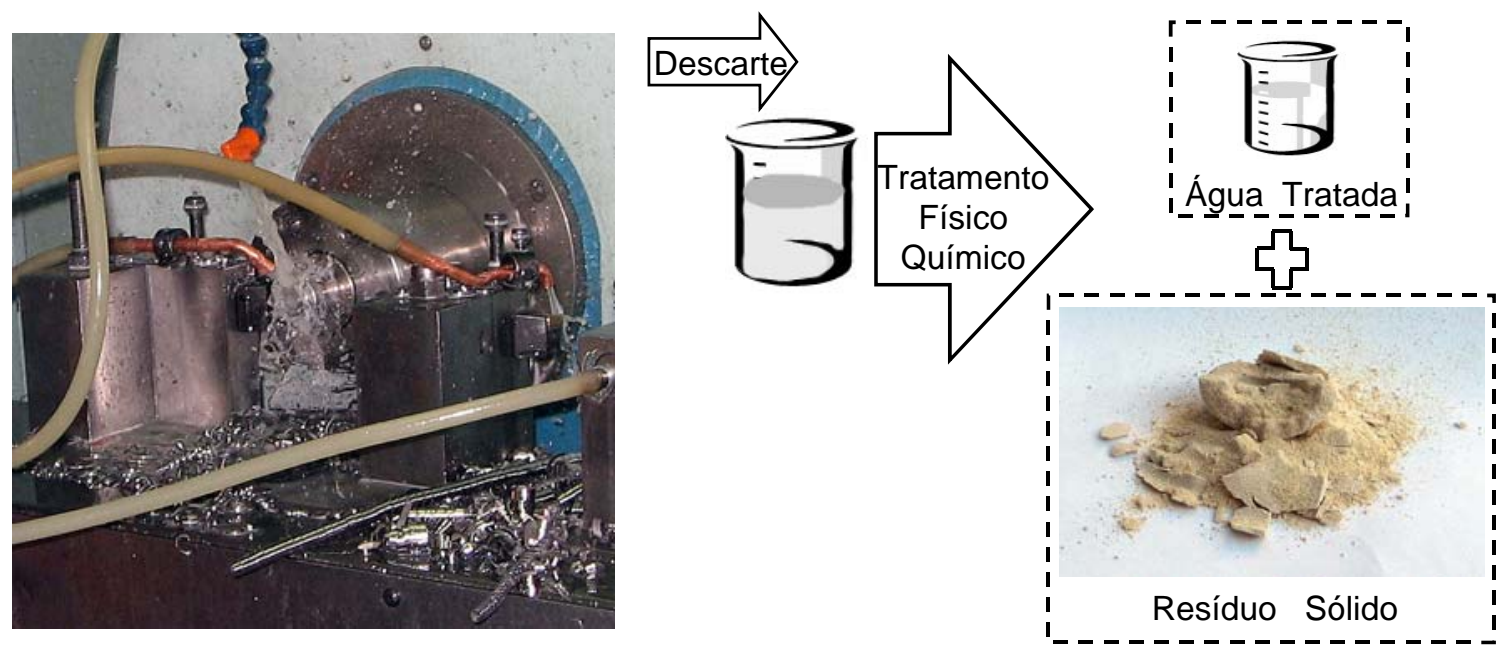

Figura 3.5 - O fluido de corte em operação e os resíduos após o tratamento.

Este foco experimental pretende evidenciar a importância de adoção dos procedimentos adequados para o descarte dos fluidos de corte, portanto a reciclagem transformando 
resíduo em insumo deverá ser abordada em estudos posteriores. A caracterização tem o propósito de verificar a contaminação por metais (toxicidade). Para a água, critérios são estipulados por padrão do artigo 18 da Lei Estadual n ${ }^{\circ}$ 997, de 31 de maio de 1976, e para o resíduo sólido a classificação segue a norma NBR 10.004.

\subsection{Executar os Experimentos}

A execução dos experimentos conta com a colaboração das empresas parceiras do laboratório OPF que oferecem suporte técnico e doam os materiais empregados. A "Sandvik Coromant", que é denominada "Ferramenta A", fornece insertos e seus respectivos suportes, a "Microquímica", denominada "Fluido A" fornece o fluido de corte e os produtos para o tratamento após o descarte.

Por sugestão do corpo técnico da empresa em estudo são empregados, durante os ensaios, as ferramentas dos fabricantes "Iscar", denominado "Ferramenta B", "Taegutec", denominado "Ferramenta C" e o fluido de corte do fabricante "Rocol", denominado "Fluido B".

\subsubsection{Ensaios de Usinagem}

Os ensaios de usinagem são realizados em um torno CNC, da marca "Starmachine", fabricado no ano 2004, em São Paulo, SP, do qual podem ser vistos a área de usinagem e o painel de comando na Figura 3.6.

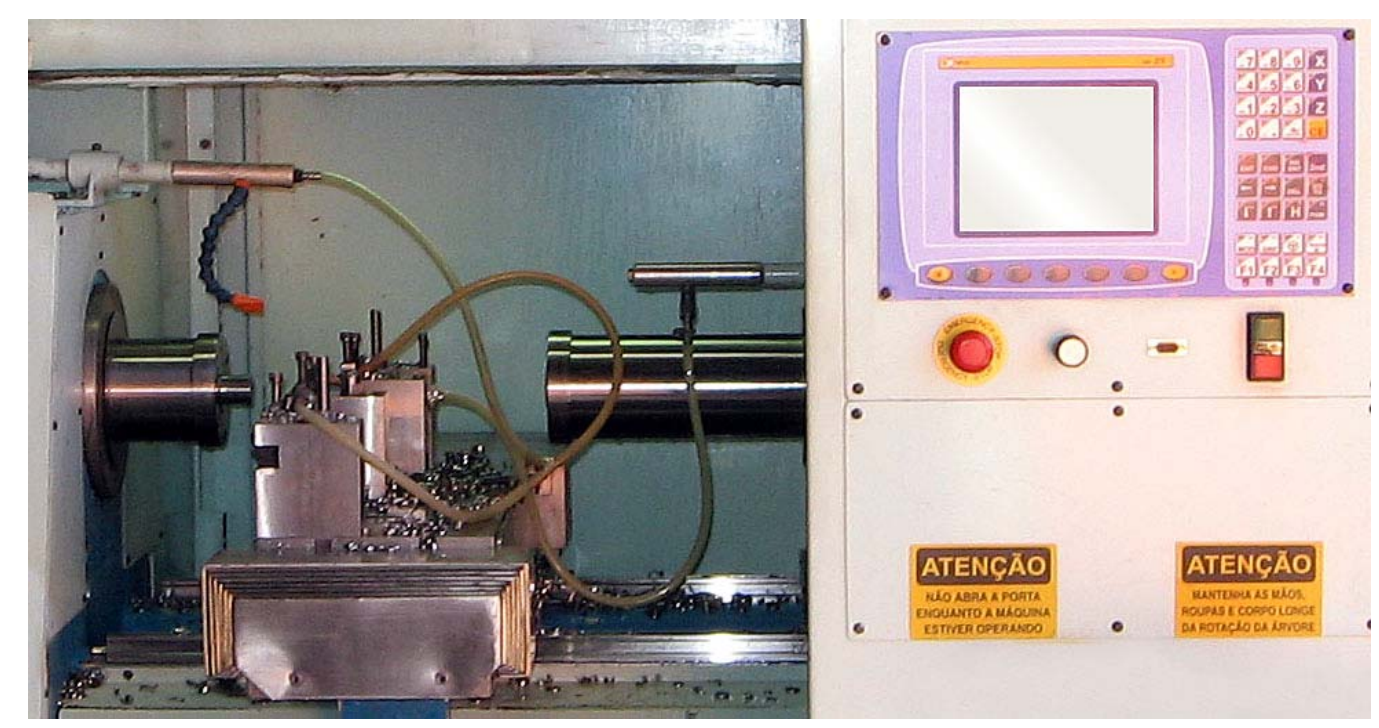

Figura 3.6 - Detalhe do torno CNC empregado nos ensaios de usinagem. 
Dados técnicos do torno e seus sistemas:

- Potência: $10 \mathrm{cv}$.

- Rotação máxima : 4000 rpm.

- Pinça de acionamento hidráulico diâmetro máximo : $40 \mathrm{~mm}$

- Guias lineares com patins - Marca: Ibatech.

- Carro porta ferramentas tipo "gang".

- Conjunto CNC*: Marca: MCS Modelo: SX570 - T.

* (comando numérico computadorizado)

- Alimentador automático para 12 barras de 3m. Marca: "Starmachine".

A proposta dos ensaios é simular as condições de produção e nesta situação equacionar as limitações do equipamento e as geradas pela falta de conhecimento técnico da equipe.

O principal questionamento é como se comporta o equipamento em regimes de máxima rotação e potência e qual a possibilidade de trabalhar com barras de três metros de comprimento nestes regimes. Estes tópicos são explorados lenta e progressivamente, iniciando com o modo de operação usual da empresa (rotação máxima $2500 \mathrm{rpm}$ ). Neste contexto os ensaios são realizados em duas fases, registradas no Diário de Campo, Apêndice C.

\section{Ensaios de Usinagem Fase I}

Os objetivos dos ensaios nesta fase são verificar o processo proposto e simular condições de produção, o comprimento de barra máximo é oitenta centímetros, com o eixo árvore parado durante a alimentação, a rotação limite é 3500 rpm.

Os materiais empregados nesta fase são:

- Material usinado: aço ABNT 1020 (certificado pelo fabricante).

- Fluido de corte Ultracut 370, tipo: semi-sintético, solução em água, concentração: 5\%, Brix 3, fabricante: "Fluido B".

- As ferramentas de corte estão relacionadas na Tabela 3.1. 
Tabela 3.1 - Especificações das ferramentas utilizadas nos ensaios.

\begin{tabular}{|c|c|c|c|c|c|c|}
\hline \multirow{2}{*}{$\begin{array}{l}{ }^{*} \text { Código do inserto } \\
{ }^{* *} \text { Código do suporte }\end{array}$} & \multicolumn{2}{|c|}{ Parâmetros recomendados } & \multicolumn{2}{|c|}{ Parâmetros ótimos } & \multirow{2}{*}{ Cobertura } & \multirow{2}{*}{ Fabricante } \\
\hline & $\mathrm{v}_{\mathrm{c}} \mathrm{m} / \mathrm{min}$ & $\mathrm{f} \mathrm{mm} / \mathrm{rot}$ & $\mathrm{v}_{\mathrm{c}} \mathrm{m} / \mathrm{min}$ & $\mathrm{f} \mathrm{mm} / \mathrm{rot}$ & & \\
\hline $\begin{array}{r}{ }^{*} \text { TNMG } 160408 \text { L-K } \\
{ }^{* * *} \text { PTFNR } 2020 \text { K16 }\end{array}$ & 230 a 485 & 0,10 a 0,80 & 220 & 0,15 & TiN & "Ferramentas A" \\
\hline $\begin{array}{c}{ }^{*} \mathrm{~N} 123 \mathrm{~F} 2-0250-0002-\mathrm{CM} \\
{ }^{* *} \mathrm{RF} 123 \mathrm{~F} 20-2020 \mathrm{~B}\end{array}$ & 125 a 255 & 0,05 a 0,15 & $* * *$ & $* * *$ & TiN & "Ferramentas A" \\
\hline $\begin{array}{l}{ }^{*} \text { WNMG } 0604 \text { 08-WF } \\
{ }^{* *} \text { MWLNR 2020K } 06\end{array}$ & 285 a 540 & 0,10 a 0,50 & $* * *$ & $* * *$ & TiN & "Ferramentas A" \\
\hline $\begin{array}{l}{ }^{*} \text { DGR 2202C-6D } \\
{ }^{* *} \text { DGTR 20B 2D } 35\end{array}$ & 50 a 150 & 0,05 a 0,18 & 132 & 0,15 & TiCN & "Ferramentas B" \\
\hline
\end{tabular}

As ferramentas em estudo são o inserto triangular com aresta aguda, para facear (TNMG 160408 L-K), empregado no desbaste para o diâmetro de 17,95 mm, o inserto trigonal do tipo "Wiper" (WNMG 0604 08-WF) realiza o acabamento e o inserto de corte (N123F2-0250-0002-CM) deve usinar o diâmetro de $25 \mathrm{~mm}$, chanfrar e cortar a peça, sendo posteriormente substituído pelo inserto de corte (DGR-2202C-6D) com a largura " $\mathrm{l}_{\mathrm{a}}$ " dois milímetros.

As atividades têm início com a discussão do processo, o operador monta as ferramentas e insere no programa CNC os parâmetros de corte iniciais, para cada superfície a menor velocidade de corte $\left(\mathrm{v}_{\mathrm{c}}\right)$ e avanço (f), que podem ser encontrados na Tabela 3.2, a profundidade de corte $\left(a_{p}\right)$ e o avanço (f) são determinados em função do raio de ponta da ferramenta $\left(r_{c}\right)$. O programa é acionado sem usinar (em vazio).

Tabela 3.2 - Parâmetros de corte avaliados nos ensaios.

\begin{tabular}{|c|c|c|c|c|c|c|c|c|c|c|c|c|}
\hline \multirow{2}{*}{$\begin{array}{c}\text { Rotação } \\
\text { máxima } \\
(\mathrm{rpm})\end{array}$} & \multicolumn{4}{|c|}{ diâmetro $17,95 \mathrm{~mm}$} & \multicolumn{4}{c|}{ diâmetro $25,00 \mathrm{~mm}$} & \multicolumn{4}{c|}{ diâmetro 10,50 mm } \\
\cline { 2 - 14 } & $\mathrm{v}_{\mathrm{c}}$ & $\mathrm{f}$ & $\mathrm{f}$ & $\mathrm{f}$ & $\mathrm{v}_{\mathrm{c}}$ & $\mathrm{f}$ & $\mathrm{f}$ & $\mathrm{f}$ & $\mathrm{v}_{\mathrm{c}}$ & $\mathrm{f}$ & $\mathrm{f}$ & $\mathrm{f}$ \\
\hline 2500 & 141 & 0,15 & 0,20 & 0,25 & 196 & 0,05 & 0,10 & 0,18 & 82 & 0,05 & 0,10 & 0,15 \\
\hline 3000 & 170 & 0,15 & 0,20 & 0,25 & 235 & 0,05 & 0,10 & 0,18 & 100 & 0,05 & 0,10 & 0,15 \\
\hline 3500 & 198 & 0,15 & 0,20 & 0,25 & 275 & 0,05 & 0,10 & 0,18 & 115 & 0,05 & 0,10 & 0,15 \\
\hline
\end{tabular}

* as unidades para $\mathrm{v}_{\mathrm{c}}=\mathrm{m} / \mathrm{min}$ e $\mathrm{f}=\mathrm{mm} / \mathrm{rot}$

O passo seguinte é verificar individualmente o desempenho de cada ferramenta, analisando seu comportamento juntamente ao do torno (ruído e vibração mecânica). A qualidade da superfície produzida tem as dimensões controladas utilizando paquímetro e micrômetro centesimal, o acabamento recebe inspeção visual e por fim a avaliação do 
tipo de cavaco. Verificações do estado das arestas de corte utilizando lupa manual permitem comprovar o bom funcionamento do processo.

As ferramentas tem os parâmetros de corte variados segundo a Tabela 3-2, para estabelecer a condição ótima de operação para a simulação de produção, aquelas com desempenho inadequado são analisadas durante os ensaios pela equipe de pesquisa OPF que se desloca até a empresa. Ao analisar o inserto de corte com lupa manual é possível verificar marcas de desgaste lateral indicando que seu alinhamento deve ser corrigido. A rigidez na fixação do bloco porta ferramenta deve ser incrementada com o emprego de calços visando limitar possíveis oscilações.

As correções de alinhamento e fixação do inserto de corte (N123F2-0250-0002-CM) proporcionam melhoras sem, no entanto, atingir uma condição de operação desejável. A ferramenta vibra em todas as operações e, por sugestão do operador, é substituída por inserto, com a largura "la" dois milímetros, cobertura $(\mathrm{TiCN})$ e a ponta com ângulo do tipo "anti-pip".

O inserto trigonal que não proporciona o acabamento desejado é substituído pelo inserto triangular para, após o desbaste, efetuar um passe de acabamento e os chanfros, economizando o tempo do deslocamento da mesa para a troca de ferramentas.

Determinada a configuração das ferramentas, o ajuste do processo passa pela investigação do compromisso entre os "parâmetros de corte ótimos" e a redução do tempo do ciclo de produção de uma peça, registrado no painel de comando CNC. Para cada alteração de avanço (f) ou velocidade de corte $\left(\mathrm{v}_{\mathrm{c}}\right)$, as superfícies usinadas são avaliadas assim como o tipo de cavaco, o comportamento da ferramenta, do torno e do alimentador automático.

Com o processo devidamente preparado é possível dar seguimento aos ensaios em condição de produção e verificar os tempos de vida das arestas de corte dos insertos, para então analisar a sua viabilidade.

O término do período determinado para os ensaios leva à interrupção da "Fase I". As arestas empregadas nos ensaios são analisadas com auxílio de microscópio da marca "Zeiss", modelo Stemi 2000-C e fotografadas com câmera da marca "Zeiss", modelo 
AxioCam MRC. Os dados obtidos são discutidos pela equipe OPF, que sugere uma segunda fase de ensaios.

\section{Ensaios de Usinagem Fase II}

Nesta fase os objetivos são verificar a vida das arestas de corte (em minutos), aumentar a produtividade do processo reduzindo o tempo do ciclo de produção, alimentar com barras medindo três metros de comprimento, com o eixo árvore em movimento e explorar a rotação máxima 4000 rpm.

Os materiais empregados nesta fase são:

- Material usinado: aço ABNT 1020 (certificado pelo fabricante).

- Fluido de corte Bio G 517, tipo: sintético, solução em água, concentração: 5\% Brix 3, fabricante: "Fluido A".

As ferramentas de corte estão relacionadas na Tabela 3.3.

Tabela 3.3 - Especificações das ferramentas utilizadas nos ensaios

\begin{tabular}{|c|c|c|c|c|c|c|}
\hline \multirow{2}{*}{$\begin{array}{l}{ }^{*} \text { Código do inserto } \\
{ }^{* *} \text { Código do suporte }\end{array}$} & \multicolumn{2}{|c|}{ Parâmetros recomendados } & \multicolumn{2}{|c|}{ Parâmetros ótimos } & \multirow{2}{*}{ Cobertura } & \multirow{2}{*}{ Fabricante } \\
\hline & $\mathrm{v}_{\mathrm{c}} \mathrm{m} / \mathrm{min}$ & $\mathrm{f} \mathrm{mm/rot}$ & $\mathrm{v}_{\mathrm{c}} \mathrm{m} / \mathrm{min}$ & $\mathrm{f} \mathrm{mm} / \mathrm{rot}$ & & \\
\hline $\begin{array}{l}{ }^{*} \text { TNMG } 160408 \text { L-K } \\
{ }^{* *} \text { PTFNR } 2020 \text { K16 }\end{array}$ & 230 a 485 & 0,10 a 0,80 & 200 & 0,15 & TiN & "Ferramentas A" \\
\hline $\begin{array}{c}{ }^{*} \text { N123E2-0200-0002-CM } \\
{ }^{* *} \text { RF123E15-2020B }\end{array}$ & 125 a 255 & 0,05 a 0,15 & 180 & 0,12 & TiN & "Ferramentas A" \\
\hline $\begin{array}{l}{ }^{*} \text { TNMG } 160408 \mathrm{MT} \\
{ }^{* *} \text { MT 1NR 2020K16 }\end{array}$ & 350 & 0,17 a 0,50 & $* * *$ & $* * *$ & $\mathrm{TiN}$ & "Ferramentas C" \\
\hline
\end{tabular}

*** Ferramenta excluída do processo.

As ferramentas em estudo são: inserto, triangular com aresta aguda para facear (TNMG $160408 \mathrm{~L}-\mathrm{K})$, inserto triangular com aresta aguda para cilindrar (TNMG $160408 \mathrm{MT}$ ) e inserto de corte (N123E2-0200-0002-CM).

A discussão com o operador especifica a montagem das ferramentas com ênfase na rigidez e posicionamento, garantindo a altura correta, facilidade no monitoramento do estado da aresta de corte e paralelismo com o eixo de deslocamento. O inserto de corte é ajustado com um desvio de paralelismo de dois centésimos de milímetro em cento e vinte milímetros de deslocamento utilizando relógio apalpador da marca Mitutoyo (resolução $0,01 \mathrm{~mm}$, capacidade $0,1 \mathrm{~mm}$ ), sustentado por base magnética, este desvio 
equivale a dois micrometros em onze e meio milímetros de percurso do inserto sobre a peça.

Por sugestão do corpo técnico é verificada uma condição de corte mais agressiva (maior profundidade de corte). A operação de desbaste em faceamento é substituída com a utilização de ferramenta equivalente para cilindrar. Através da variação dos parâmetros de corte não é possível evitar a formação de cavaco em "fita emaranhado" considerado inadequado.

Durante a simulação de produção (com o processo determinado), inicia a investigação para as condições de alimentação, o comprimento da barra de oitenta centímetros $(0,80$ m) é substituído progressivamente por: $1,60 \mathrm{~m}, 2,40 \mathrm{~m}$ e 3,00 m e verificam-se, para cada situação, as condições de operação e eventuais reflexos na qualidade das peças produzidas. Comprovada a possibilidade de trabalhar com barras longas a alimentação é então realizada com o eixo árvore em movimento proporcionando redução do tempo do ciclo.

Realizados todos os ajustes, o processo em condições de produção é monitorado até o limite de vida das arestas de corte, o que encerra a "Fase II" dos ensaios de usinagem.

Utilizando o microscópio da marca "Zeiss", modelo Stemi 2000-C é possível verificar os desgastes das arestas estudadas que são fotografadas com câmera da marca "Zeiss", modelo AxioCam MRC, e a equipe OPF avalia os resultados da fase de ensaios.

\subsubsection{Tratamento e Caracterização}

Com a proposta de regularizar a cadeia de resíduos a execução do terceiro foco experimental é dividida em duas partes, a primeira é o tratamento do fluido de corte na fase de descarte, coordenada pelo especialista em tratamento de efluentes, a segunda parte, a caracterização da água e o resíduo sólido resultantes é conduzida por técnicos do laboratório (LRQ - USP - SC).

Em uma sessão com duração aproximada de duas horas, na bancada do laboratório LRQ, o coordenador do experimento apresenta três alternativas de tratamento, que

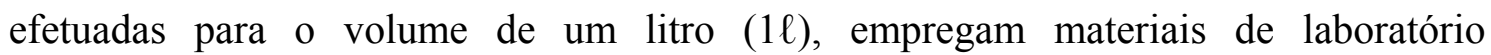


convencionais e os produtos "Microtrat" do mesmo fabricante do fluido de corte em estudo.

\section{- Tratamento “ 1 ”}

O inicio do tratamento é a quebra da solução (quebra ácida), que ocorre com a adição de ácido tricloroacético (produto $\mathrm{N}^{\mathrm{o}} 26$ ), na proporção de $3 \mathrm{~m} \ell / \ell$ (três mililitros por litro). A solução é agitada até haver flotação, com a formação de uma fase limpa.

A próxima reação é a separação dos metais pelo processo de precipitação, realizada em meio básico através da adição de hidróxido de cálcio (produto $\mathrm{N}^{\mathrm{o}} 25$ ), na proporção de $5 \mathrm{~m} \ell / \ell$ (cinco mililitros por litro).

A adição de um polímero (produto $\mathrm{N}^{\mathrm{o}} 14$ ), na proporção de $0,02 \mathrm{~g} / \mathrm{l}$, com função aglutinante, favorece a floculação, aumentando a eficiência do tratamento.

O último procedimento é o processo de filtragem do efluente. Após secagem por evaporação natural, a fase sólida, e água (fase líquida) são encaminhadas para a analise.

O tratamento é repetido de duas formas alternativas, visando a comparação de resultados e são denominados, "1", “2” e "3" respectivamente.

\section{- Tratamento “2”}

A segunda alternativa repete os procedimentos do tratamento "1" com a adição de carvão ativado após a etapa de precipitação, com o propósito de melhorar a filtragem da água no final do processo.

\section{- Tratamento “3”}

A terceira alternativa é a realização da quebra ácida substituindo o ácido tricloroacético por cloreto férrico. Este tratamento é adotado por ser bastante conhecido e de baixo custo, porém com o inconveniente do aumento de íons de ferro no resíduo sólido.

\section{Caracterização}

A água e o resíduo sólido resultantes do tratamento são caracterizados segundo a concentração de metais medida com um Espectrofotômetro de Absorção Atômica (AA), da marca Varian, modelo AA - 1275. Este equipamento utiliza padrões dos metais que 
devem ser detectados permitindo medir a concentração (traço) de cada metal na água analisada. Para analisar a taxa de metais nos resíduos sólidos, as amostras são submetidas ao processo de digestão ácida, a solubilização dos metais em solução aquosa. Desta forma é possível verificar os diferentes resultados dos tratamentos, a qualidade da água e a classificação dos resíduos sólidos, que são apresentados no item 4.3 Tratamento e Caracterização.

\subsection{Organizar dados e avaliar resultados}

A parte experimental descrita é finalizada com a organização dos dados, os cálculos de tempo de vida da aresta dos insertos empregados nos ensaios e um balanço de custos relativos a ferramentas, fluido de corte, matéria prima e hora máquina.

A quantificação dos resultados obtidos nas intervenções permite visualizar os ganhos econômicos, ambientais e sociais além de quais itens, na composição do custo da peça, são os que mais oneram a produção merecendo investimento da empresa. Os números são apresentados para discussão na equipe OPF, que determina o encerramento dos ensaios, convidando corpo técnico da empresa a elaborar um parecer técnico sobre a interação. 


\section{DISCUSSÃO E RESULTADOS}

Com este capítulo é possível avaliar os resultados do trabalho de campo e suas propostas na interação com as empresas envolvidas no estudo. A sua estrutura é apresentada nas seguintes subdivisões: apresentação do "cenário", ensaios de usinagem, tratamento e caracterização, discussão dos ganhos e repercussão na empresa e finalizando, a projeção de possibilidades no parque industrial. A organização e discussão relativa a cada etapa da pesquisa proporcionam o respaldo para $\mathrm{o}$ encerramento das atividades.

\subsection{Apresentação do Cenário}

O cenário construído com os dados das onze empresas envolvidas no estudo proporciona uma amostra da situação dos processos de usinagem nas micro, pequenas e médias empresas (PME’s) de São Carlos.

Ao conhecer o corpo técnico e as instalações é possível a análise do perfil industrial e o contexto em que está inserida a usinagem.

Convém observar que em todas as empresas onde esteve a equipe de pesquisa "OPF" foi grande a receptividade e disposição em colaborar com o estudo proposto.

Em uma apresentação inicial do grupo estudado vale observar que todas as empresas são de capital nacional, sólidas, com boa posição de mercado e carteira de clientes estabelecida.

A Tabela 4.1 apresenta o perfil das empresas que são referenciadas através das letras de A até $\mathrm{K}$. 
Tabela 4.1 Perfil das empresas de A até K envolvidas no estudo.

\begin{tabular}{|c|c|c|c|c|c|c|c|c|}
\hline & Ramo & $\begin{array}{l}\text { Assistência } \\
\text { Técnica }^{(1)}\end{array}$ & $\begin{array}{l}\text { Máquinas } \\
\mathrm{CNC}^{(2)}\end{array}$ & $\begin{array}{c}\text { Ferramentas } \\
\text { sofisticadas }\end{array}$ & Engenheiros & Técnicos & Funcionários & $\begin{array}{c}\text { Faturamento } \\
\text { anual }^{(4)}\end{array}$ \\
\hline A & $\begin{array}{c}\text { Máquinas } \\
\text { Automação }\end{array}$ & $\operatorname{sim}$ & 4 & $\operatorname{sim}$ & 8 & 15 & 75 & Média \\
\hline B & $\begin{array}{l}\text { Ferramentas } \\
\text { Automação }\end{array}$ & $\operatorname{sim}$ & 5 & $\operatorname{sim}$ & 1 & 6 & 60 & Média \\
\hline C & Usinagem & $\operatorname{sim}$ & 4 & $\operatorname{sim}$ & 2 & 2 & 35 & Pequena \\
\hline D & $\begin{array}{c}\text { Equipamento } \\
\text { industrial }\end{array}$ & $\operatorname{sim}$ & 4 & $\operatorname{sim}$ & 4 & 4 & 55 & Média \\
\hline $\mathbf{E}$ & $\begin{array}{l}\text { Equipamento } \\
\text { de saúde }\end{array}$ & $\operatorname{sim}$ & 4 & $\operatorname{sim}$ & 25 & 15 & 200 & Média \\
\hline $\mathbf{F}$ & Máquinas & $\operatorname{sim}$ & 6 & $\operatorname{sim}$ & 9 & 7 & 150 & Média \\
\hline G & $\begin{array}{c}\text { Máquinas } \\
\text { Automação }\end{array}$ & $\operatorname{sim}$ & 1 & $\operatorname{sim}$ & 4 & 4 & 35 & Média \\
\hline $\mathbf{H}$ & $\begin{array}{l}\text { Ferramentas } \\
\text { Máquinas }\end{array}$ & $\operatorname{sim}$ & 5 & $\operatorname{sim}$ & não & 30 & 56 & Média \\
\hline I & $\begin{array}{c}\text { Manutenção } \\
\text { Usinagem }\end{array}$ & $\operatorname{sim}$ & não & $\operatorname{sim}$ & 1 & 3 & 9 & Micro \\
\hline $\mathbf{J}$ & $\begin{array}{l}\text { Máquinas } \\
\text { Usinagem }\end{array}$ & não & não & $\operatorname{sim}$ & não & não & 7 & Micro \\
\hline $\mathbf{K}$ & Ferramentas & não & não & não & não & não & 3 & Micro \\
\hline
\end{tabular}

1- Refere-se ao recebimento de assistência técnica em relação às máquinas, ferramentas e fluidos de corte.

2- Refere-se a máquinas com controle numérico computadorizado (CNC).

3- Refere-se ao emprego de insertos recobertos na usinagem.

4- Classificação segundo o Estatuto da Microempresa e da Empresa de Pequeno Porte.

Ao analisar os dados, verifica-se que, predominam empresas de médio porte que segundo SEBRAE (2005b) é estipulado pelo "Estatuto da Microempresa e da Empresa de Pequeno Porte" como aquelas, com faturamento anual superior a $\mathrm{R} \$ 2.133 .222,00$ (dois milhões, cento e trinta e três mil, duzentos e vinte e dois reais). Apenas uma delas 
é classificada pequena e três são microempresas com receita bruta anual igual ou inferior a $\mathrm{R} \$ 433.755,14$ (quatrocentos e trinta e três mil, setecentos e cinqüenta e cinco reais e quatorze centavos).

Se o critério adotado for o número de empregados três são microempresas, seis são pequenas (20 a 99 empregados) e duas médias (100 a 499 empregados).

Avaliando o equipamento de usinagem é significativo o emprego de máquinas $\mathrm{CNC}$ (comando numérico computadorizado) e ferramentas do tipo inserto recoberto. Contar com o suporte de assistência técnica para as máquinas, ferramentas e fluidos de corte é pratica comum nestas empresas excetuadas duas das microempresas.

A qualificação da mão de obra é outra qualidade destas empresas, o que as torna propícias para absorver novas tecnologias e contextos de produção.

Convém observar que, para mais da metade das empresas relacionadas, a usinagem não está no foco dos negócios, sendo área de suporte. Ao visitar as oficinas observa-se uma postura bastante conservadora em relação aos aspectos da usinagem e fica evidente que, com o devido suporte, estes processos podem ser conduzidos a patamares mais elevados de qualidade e produtividade.

Ao abordar o emprego de fluidos de corte, verifica-se a carência de conhecimento a respeito deste auxiliar de processo. A preocupação com a saúde do operador é consenso refletindo no emprego de fluidos de corte sintéticos, mas a aplicação é sempre abundante, e nenhuma empresa executa a usinagem, com a aplicação de mínima quantidade de fluido (MQF). Cuidados com a manutenção do fluido em operação como filtragem ou aditivação não são procedimentos comuns.

As questões ambientais tornam-se relevantes quando muitos dos entrevistados desconhecem a respeito da disposição final do fluido usado, devendo ser objeto de estudo. A Tabela 4.2 evidencia a situação descrita. 
Tabela 4.2 Fluidos de corte nas empresas de A até K.

\begin{tabular}{|c|c|c|c|c|c|c|c|c|}
\hline & Tipos & aplicação & MQF & Armazenamento & Filtragem & Aditivação & Critérios descarte & Disposição final \\
\hline A & sintético & abundante & não & $\begin{array}{c}80 \text { litros } \\
\text { almoxarifado }\end{array}$ & não & não & vida em meses & $\bullet$ \\
\hline B & - & abundante & não & - & $\operatorname{sim}$ & não & - & $\bullet$ \\
\hline $\mathrm{C}$ & sintético & abundante & não & $\begin{array}{c}200 \text { litros } \\
\text { oficina }\end{array}$ & não & não & visual & em estudo \\
\hline $\mathrm{D}$ & sintético & abundante & não & $\begin{array}{c}80 \text { litros } \\
\text { almoxarifado }\end{array}$ & não & não & visual & $\bullet$ \\
\hline E & sintético & abundante & não & $\bullet$ & não & não & - & - \\
\hline $\mathrm{F}$ & sintético & abundante & não & $\begin{array}{c}200 \text { litros } \\
\text { almoxarifado }\end{array}$ & não & não & vida em horas & $\begin{array}{l}\text { Segundo } \\
\text { legislação }\end{array}$ \\
\hline G & $\begin{array}{l}\text { mineral e } \\
\text { sintético }\end{array}$ & abundante & não & $\begin{array}{c}50 \text { litros } \\
\text { almoxarifado }\end{array}$ & não & não & visual & - \\
\hline $\mathrm{H}$ & $\begin{array}{l}\text { sintético } \\
\text { semi sint. }\end{array}$ & controlada & não & $\begin{array}{c}400 \text { litros } \\
\text { almoxarifado }\end{array}$ & não & não & $\begin{array}{c}\text { verificação } \\
\text { periódica }\end{array}$ & $\begin{array}{c}\text { Empresa } \\
\text { especializada }\end{array}$ \\
\hline I & $\begin{array}{l}\text { mineral e } \\
\text { sintético }\end{array}$ & abundante & não & $\begin{array}{c}60 \text { litros } \\
\text { almoxarifado }\end{array}$ & não & não & $\begin{array}{l}\text { desempenho/ } \\
\text { contaminação }\end{array}$ & $\begin{array}{c}\text { Empresa } \\
\text { especializada }\end{array}$ \\
\hline $\mathrm{J}$ & sintético & abundante & não & 20 litros & não & não & em estudo & em estudo \\
\hline $\mathrm{K}$ & $\begin{array}{c}\text { mineral e } \\
\text { sintético }\end{array}$ & abundante & não & 20 litros & não & não & visual & - \\
\hline
\end{tabular}

- O representante da empresa desconhece ao responder o questionário durante a visita. 


\subsection{Ensaios de Usinagem}

Conduzidos nas instalações da empresa em estudo os ensaios cumprem a proposta de levar uma nova abordagem aos processos de usinagem. Os conceitos empregados proporcionam a capacitação do corpo técnico e ganhos nos aspectos econômico, social e ambiental.

Os ensaios de usinagem são conduzidos seguindo a dinâmica de produção da empresa e seus padrões de desempenho. Isto é evidenciado na divisão dos ensaios (em duas fases) e nas referências utilizadas para verificar a dimensão dos ganhos nas intervenções.

As avaliações são divididas em dois focos experimentais. O primeiro foco experimental aborda a tecnologia de usinagem no emprego do inserto triangular com aresta aguda e o segundo, a economia de recursos através da redução da largura de corte da peça.

\subsubsection{Tecnologia de Usinagem e Otimização do Processo}

O custo da hora máquina é elevado, sendo superado apenas pelo custo do aço (APÊNDICE E). A maior confiabilidade do processo e a redução do tempo de corte resultam em significativa redução do custo de fabricação, devem ser considerados ainda; os ganhos relativos a um número menor de peças produzidas fora das especificações, resultando em perdas, ou necessidade de operações corretivas, a manutenção de um padrão de qualidade constante e a previsibilidade do processo.

O inserto triangular com aresta aguda para facear (TNMG $160408 \mathrm{~L}-\mathrm{K}$ ) viabiliza o desbaste em passe único e permite a redução do tempo de corte. O ciclo de produção da peça passa de 41 para 32 segundos, com a qualidade desejada (dimensão e acabamento), confiabilidade (processo estável) e cavaco adequado (espiral curto).

O desempenho do torno recebe boa avaliação, proporcionando repetibilidade e produção nas condições de tolerâncias e acabamento determinadas, com vibrações e ruídos dentro dos padrões normais de operação, não sendo possível trabalhar em regime de potência máxima em função do acabamento gerado com um avanço de corte superior a 0,15 $\mathrm{mm} /$ rotação. 
Os ensaios foram realizados em duas fases empregando três arestas de corte denominadas, aresta “1”, “2” e "3" seguindo esta ordem.

\section{Ensaios de Usinagem Fase I}

Na Fase I foi empregada a aresta “1”, que usinou 307 peças, em um tempo de corte 9,07 minutos. O desgaste de flanco não ultrapassa 0,1 milímetro, sendo possível prever a utilização da aresta até um desgaste de 0,3 milímetro. Inserida na Tabela 4.3 com os dados do ensaio a Figura 4.1 mostra fotografia do desgaste de flanco da aresta "1" após o encerramento do ensaio.

Tabela 4.3 - Dados do ensaio de vida da aresta de corte.

\begin{tabular}{|c|c|c|c|}
\hline & \multirow{3}{*}{ Fase I - aresta "1" } & \multicolumn{2}{|c|}{ Parâmetros ótimos } \\
\hline & & $\mathrm{v}_{\mathrm{c}} \mathrm{m} / \mathrm{min}$ & $\mathrm{f} \mathrm{mm} / \mathrm{rot}$ \\
\hline & & 220 & 0,15 \\
\hline & Inserto triangular & \multicolumn{2}{|c|}{ Duração do ensaio } \\
\hline & TNMG 160408 L-K & Peças & Minutos \\
\hline Figura 4.1 Foto aresta "1". & Fabricante "A" & 307 & 9,07 \\
\hline
\end{tabular}

O ensaio é interrompido para respeitar o cronograma de produção da empresa. As peças são produzidas com as dimensões especificadas e o acabamento desejado.

\section{Ensaios de Usinagem Fase I I}

$\mathrm{Na}$ Fase II foram empregadas duas arestas. A aresta " 2 " executou 249 peças equivalente à 8,10 minutos de tempo de corte, sendo substituída com a justificativa de perda de controle do processo, que em um lote de dez peças, produz três fora da dimensão especificada. Após verificações de apertos do inserto, porta ferramenta e bloco porta ferramenta a opção é dar segmento à simulação de produção utilizando nova aresta. Inserida na Tabela 4.4 com os dados do ensaio a Figura 4.2 mostra fotografia do desgaste de flanco da aresta " 2 " após ser substituída. 
Tabela 4.4 - Dados do ensaio de vida da aresta de corte.

\begin{tabular}{|c|c|c|c|}
\hline \multirow{2}{*}{ E } & \multirow{2}{*}{ Fase II - aresta "2" } & \multicolumn{2}{|c|}{ Parâmetros ótimos } \\
\cline { 3 - 4 } & & $\mathrm{v}_{\mathrm{c}} \mathrm{m} / \mathrm{min}$ & $\mathrm{f} \mathrm{mm/rot}$ \\
\cline { 3 - 4 } & & 220 & 0,15 \\
\cline { 2 - 4 } & Inserto triangular & \multicolumn{2}{|c|}{ Duração do ensaio } \\
\cline { 2 - 4 } Figura 4.2 - Foto aresta "2". & TNMG 16 04 08 L-K & Peças & Minutos \\
\cline { 2 - 4 } & Fabricante "A" & 249 & 8,10 \\
\hline
\end{tabular}

O ensaio tem segmento com a aresta "3" que executa 223 peças, equivalente à 7,25 minutos de tempo de corte. Todas as peças são produzidas segundo as especificações conduzindo a interpretação de que a confiabilidade do processo é alcançada. Com o desgaste de flanco inferior a 0,1 milímetro conclui-se que o tempo de corte pode superar as marca especificada pelo fabricante do inserto em um tempo mínimo de vida da aresta de 15 minutos. Inserida na Tabela 4.5 com os dados do ensaio a Figura 4.3 mostra fotografia do desgaste de flanco da aresta " 3 ” após o encerramento do ensaio.

Tabela 4.5 - Dados do ensaio de vida da aresta de corte.

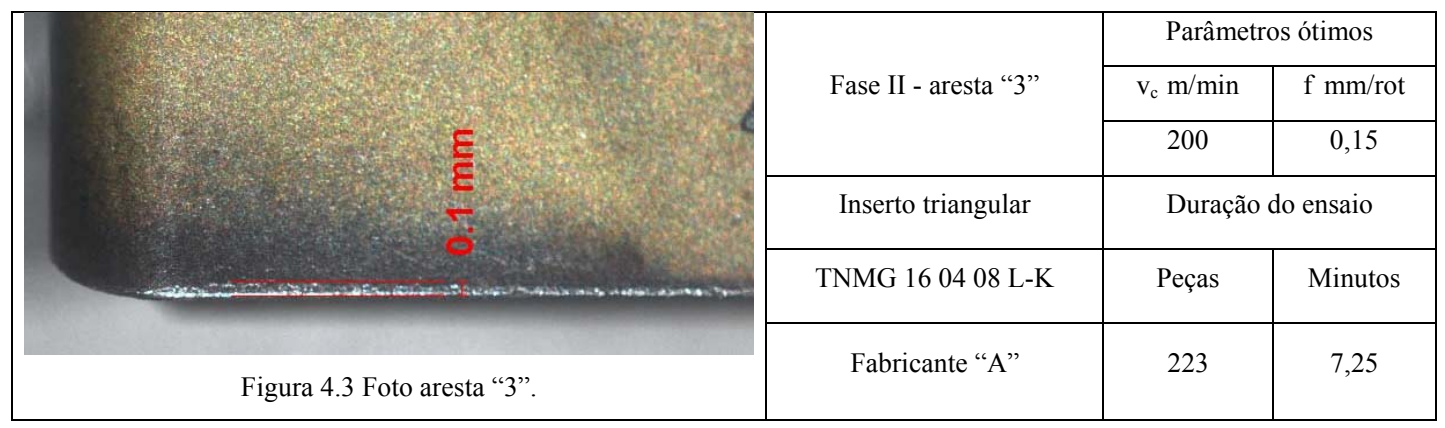

Encerrados os ensaios é possível verificar que o inserto empregado proporciona ganhos de produtividade e confiabilidade ao processo, o que é consenso para o corpo técnico da empresa, convém observar que na "Fase II" a aresta " 2 " apresenta desgaste de flanco inferior a 0,1 milímetro merecendo análise para melhor entendimento do desempenho 
insatisfatório. O tempo restrito para investigações e a cultura de produção conduzem à interpretação de que mesmo com a substituição prematura da aresta seu emprego no processo é economicamente viável com os ganhos proporcionados superando os custos de subutilização. Esta consideração aborda a pior condição e permite o encerramento dos ensaios registrando os ganhos.

No cálculo dos tempos de corte (APÊNDICE D) fica evidenciado que o tempo consumido na usinagem é inferior à metade do tempo de ciclo de produção da peça (32 segundos), portanto o deslocamento do carro porta ferramentas caracteriza-se como grande consumidor de tempo. A redução dos espaços tidos como segurança pode resultar em ganhos econômicos, considerando que a redução do tempo registrada nos ensaios de 41 segundos para 32 segundos, proporciona economia de R\$ 0,0362 por peça, abaixando o custo da hora máquina para $\mathrm{R} \$ 0,1295$. O Apêndice E apresenta os custos do processo para os aspectos que recebem intervenção.

\subsubsection{Economia de Recursos}

A redução do consumo de matéria prima (aço) e produção de resíduos são possíveis utilizando ferramenta com menor largura " $l_{a}$ ", na operação de corte da peça. Os resultados diretos são custos de insumos de fabricação menores e os ganhos ambientais relativos ao menor consumo de aço (desmaterialização).

A análise de viabilidade do emprego de uma ferramenta, menos robusta, no corte da peça é conduzida em duas fases.

\section{Ensaios de Usinagem Fase I}

A primeira etapa, o ajuste do processo evidencia a condição de sensibilidade da ferramenta ao posicionamento correto. $\mathrm{O}$ alinhamento do eixo de corte e a posição da aresta exigem controle rigoroso para evitar sobrecarga e vibrações que podem resultar em falhas ou desgaste acelerado da aresta.

Com a montagem correta e a determinação dos parâmetros de corte ótimos, o processo entra em regime de simulação de produção, interrompido ao final do prazo determinado para a realização da Fase I. 
O inserto para corte com largura de 2,00 mm (DGR 2202C-6D) executou, com uma aresta, 291 peças, equivalente a 30,44 minutos tempo de corte. Considerado o desgaste de flanco inferior a $0,1 \mathrm{~mm}$ e a qualidade do acabamento superficial regular (inspeção visual), declinando lentamente, é possível afirmar que a aresta oferece condições de continuar em operação. Inserida na Tabela 4.6 com os dados do ensaio a Figura 4.4 mostra fotografia do desgaste de flanco na aresta do inserto de corte após o encerramento do ensaio.

Tabela 4.6 - Dados do ensaio de vida da aresta de corte.

\begin{tabular}{|l|c|c|c|}
\hline \multirow{2}{*}{} & \multirow{2}{*}{ Fase I } & \multicolumn{2}{|c|}{ Parâmetros ótimos } \\
\cline { 3 - 4 } & & $\mathrm{v}_{\mathrm{c}} \mathrm{m} / \mathrm{min}$ & $\mathrm{f} \mathrm{mm} / \mathrm{rot}$ \\
\cline { 3 - 4 } & & 132 & 0,15 \\
\cline { 2 - 4 } & Inserto de Corte 2 $\mathrm{mm}$ & \multicolumn{2}{|c|}{ Duração do ensaio } \\
\cline { 2 - 4 } & DGR 2202C-6D & Peças & Minutos \\
\cline { 3 - 4 } & Fabricante "B" & 291 & 30,44 \\
\hline
\end{tabular}

\section{Ensaios de Usinagem Fase II}

A Fase II deve comprovar a viabilidade de efetuar o corte da peça com o inserto de " $l_{a}$ " 2,0 $\mathrm{mm}$ e tem a proposta de verificar a duração da vida da aresta de corte. A ferramenta empregada tem características diferentes da utilizada na fase anterior (outro fabricante), permitindo verificar que a redução da espessura de corte é possível para os dois tipos de inserto.

O inserto para corte com largura de 2,00 mm (N123E2-0200-0002-CM) executou 472 peças com uma aresta, o equivalente a 37,31 minutos tempo de corte. O encerramento do ensaio ocorre com a falha catastrófica do inserto impedindo a verificação do estado da aresta de corte e seu registro fotográfico. A Tabela 4.7 - apresenta os dados do ensaio. 
Tabela 4.7 - Dados do ensaio de vida da aresta de corte.

\begin{tabular}{|c|c|c|}
\hline \multirow{2}{*}{ Fase II } & \multicolumn{2}{|c|}{ Parâmetros ótimos } \\
\cline { 2 - 3 } & $\mathrm{v}_{\mathrm{c}} \mathrm{m} / \mathrm{min}$ & $\mathrm{f} \mathrm{mm/rot}$ \\
\cline { 2 - 3 } & 180 & 0,12 \\
\hline Inserto de Corte $2 \mathrm{~mm}$ & \multicolumn{2}{|c|}{ Duração do ensaio } \\
\hline N123E2-0200-0002-CM & Peças & minutos \\
\hline Fabricante "A" & 472 & 37,31 \\
\hline
\end{tabular}

*obs.O inserto danificado não permitiu verificação do desgaste da aresta.

O tempo de corte alcançado indica que o processo ocorre dentro das características determinadas em Sandvik Coromant (2002), onde respeitados os parâmetros estipulados no catálogo, a duração aceitável de uma aresta varia entre 15 e 40 minutos de tempo de corte.

As superfícies produzidas antes da falha catastrófica do inserto apresentam falhas e irregularidades, indicando usinagem com aresta defeituosa. O colapso da ferramenta deixa explicito a falta de experiência do operador e a necessidade de acompanhamento dos ensaios.

Avaliando o tempo de vida da aresta obtido no ensaio e a qualidade das peças produzidas é possível concluir que o corte da peça deve ser realizado com um inserto o mais fino o possível, respeitadas as limitações de custo e confiabilidade do processo.

No processo adotado para os ensaios, o inserto para corte executa operações de sangramento (canal), cilindrar e chanfrar. Considerando que esta é a ferramenta de maior custo e os ganhos relativos à redução da espessura de corte, fica evidenciado, que o processo ao ser desenvolvido, deve privilegiar a operação de corte.

Ao efetuar o balanço de custos (APÊNDICE E) verifica-se que na "Fase II" o custo de aresta por peça usinada é de R $\$ 0,0727$ e pode ser reduzido para o R $\$ 0,0365$ se for empregado apenas para efetuar o corte da peça. A economia de aço em $1 \mathrm{~mm}$ de largura de corte é R\$ 0,0204 e reduzindo a espessura de corte para 1,5 mm pode proporcionar economia de $\mathrm{R}$ \$ 0,0306 por peça. Como referência vale citar os elementos de maior custo, a hora máquina, $\mathrm{R} \$ 0,1295$ e o custo do aço por peça, somado a $3 \mathrm{~mm}$ de largura 
de corte, $\mathrm{R} \$$ 0,3427. Para obter a ordem de grandeza estes valores devem ser multiplicados pelo valor do lote de produção anual de cem mil peças.

Associados aos ganhos econômicos, estão os ganhos de redução de consumo de aço e seu transporte, proporcionando emissões de gases menores nesta etapa do ciclo de vida do produto, melhorando seu desempenho ambiental.

\subsubsection{Considerações Complementares}

Ao encerrar os ensaios de usinagem convém reforçar que parte do método de pesquisa é interagir com o corpo técnico e transmitir conceitos. A investigação sobre o desempenho do processo é limitada pela dinâmica de trabalho da empresa e pretende apenas verificar a viabilidade e os potenciais ganhos com as ferramentas propostas.

O emprego de diferentes fluidos de corte, nas fases "I" e "II", ocorre por conveniência da empresa, não sendo possível verificar sua influência no desempenho de corte durante os ensaios.

A investigação de ferramentas com características e fabricantes diversos resume-se a questões circunstanciais respondendo aos anseios do corpo técnico com a função de explorar a discussão dos conceitos de usinagem.

\subsection{Tratamento e Caracterização}

O terceiro foco experimental, a intervenção na cadeia de resíduos, tem seus resultados avaliados em duas partes, o tratamento do fluido de corte na fase de descarte e a caracterização dos produtos do tratamento.

A proposta dos experimentos é verificar a viabilidade do tratamento e a importância da adoção dos procedimentos corretos no descarte dos fluidos de corte.

\subsubsection{Tratamento}

Ao analisar os procedimentos experimentais, descritos no item 3.6.2. e os custos do tratamento efetuado (Apêndice E) conclui-se que esta é uma solução viável para as empresas, equilibrando a cadeia de resíduos e melhorando o desempenho ambiental do 
processo. Convém observar que este tipo de tratamento pode ser empregado a todos os fluidos de corte a base de água.

Das três alternativas de tratamento apresentadas o "tratamento 1" é o padrão proposto pelo fabricante do fluido de corte que também fornece os produtos para o tratamento.

O "tratamento 2" conta com a adição de carvão ativado para melhorar a qualidade da água resultante (no experimento realizado não teve efeito) valendo observar que é um insumo que permanece no resíduo como mais um elemento.

O "tratamento 3" emprega o cloreto férrico que reduziu o traço do metal ferro na água mas eleva em oitenta vezes a concentração de ferro no resíduo sólido.

As alternativas apresentadas tem a função de explicitar que o tratamento pode ser ajustado para adequar a água e a parte sólida resultantes à destinação desejada, merecendo estudos futuros.

\subsubsection{Caracterização}

Através da caracterização este trabalho propõe-se a determinar a disposição adequada para a água e o sólido resultantes do tratamento.

A água para ser descartada em um corpo hídrico deve respeitar as condições especificadas pelo artigo 18 da Lei Estadual n 997, de 31 de maio de 1976.

A Tabela 4.8 apresenta os resultados obtidos na análise da água e os valores admitidos no estado de São Paulo. 
Tabela 4.8 - Traço dos metais contaminantes e valor máximo admitido.

\begin{tabular}{|c|c|c|c|c|}
\hline $\mathrm{mg} / \ell$ & Amostra “ $1 "$ & Amostra “2” & Amostra “ 3 ” & admitido \\
\hline $\mathrm{Zn}$ & 0,09 & 0,11 & 0,10 & 5,00 \\
\hline $\mathrm{Pb}$ & $<0,02$ & 0,21 & 0,07 & 0,50 \\
\hline $\mathrm{Cd}$ & $<0,0006$ & $<0,0006$ & $<0,0006$ & 0,20 \\
\hline $\mathrm{Ni}$ & 0,04 & 0,23 & 0,17 & 2,00 \\
\hline $\mathrm{Fe}$ & 2,08 & 1,03 & 0,92 & 15,0 \\
\hline $\mathrm{Mn}$ & $\mathbf{3 2 , 0}$ & $\mathbf{3 8 , 4}$ & $\mathbf{4 0 , 7}$ & $\mathbf{1 , 0 0}$ \\
\hline $\mathrm{Cu}$ & 0,07 & 0,08 & 0,05 & 1,00 \\
\hline $\mathrm{Cr}$ & 0,10 & 0,26 & 0,19 & 5,00 \\
\hline
\end{tabular}

Analisando a tabela 4.8 verifica-se que as três alternativas de tratamento são eficazes exceto para a taxa de manganês $(\mathrm{Mn})$, que deve ser reduzida a um valor admissível. Isto é possível aumentando a alcalinidade durante a fase de precipitação dos metais.

As demandas químicas de oxigênio (DQO) e biológica (DBO) não foram analisadas. Estas medidas são relevantes e podem ser facilmente corrigidas. A DBO pela aeração do efluente e a DQO em ajustes no tratamento. Ao refinar o tratamento proposto estas medidas devem ser efetuadas.

A turbidez para as amostras "1", " 2 " e " 3 " é respectivamente 1,39 , 1,58 e 1,29 medida em NTU o que é aceitável para o descarte.

Os resultados indicam a necessidade de corrigir o tratamento para o descarte da água, o que pode ser realizado como procedimento de rotina no tratamento de efluentes pelo profissional encarregado. Com a separação da água ocorre uma redução significativa no volume do resíduo do fluido de corte descartado. 
O resíduo sólido decantado após a filtração é denominado "borra" ou "lama", seco por evaporação natural, tem a massa em proporção de dois quilogramas para cada duzentos litros de fluido de corte tratado. As concentrações de metais mais significativas para as amostras: "1", “2” e “3” estão em mg/g borra na Tabela 4-9, evidenciando o caráter de resíduo classe 1 (perigoso; toxicidade) segundo a ASSOCIAÇÃO BRASILEIRA DE NORMAS TÉCNICAS - ABNT (1986).

Tabela 4.9 - Concentrações mais significativas de metais.

\begin{tabular}{|c|c|c|c|}
\hline $\mathrm{mg} / \mathrm{g}$ & Amostra “1” & Amostra “2” & Amostra “3” \\
\hline $\mathrm{Zn}$ & 0,73 & 0,64 & 0,60 \\
\hline $\mathrm{Fe}$ & 2,41 & 1,42 & 163,79 \\
\hline $\mathrm{Mn}$ & 4,53 & 2,69 & 3,55 \\
\hline
\end{tabular}

*as concentrações são mg/g borra

Analisando a Tabela 4.9 observa-se que ocorre a contaminação do fluido de corte pelos metais durante a usinagem. O fluido analisado esteve apenas um mês em operação com a perspectiva de vida de até dois anos. A usinagem de latão resulta na contaminação por zinco e o ferro e o manganês são provenientes do aço. A Figura 4.5 apresenta os resíduos sólidos resultantes dos três tratamentos realizados.
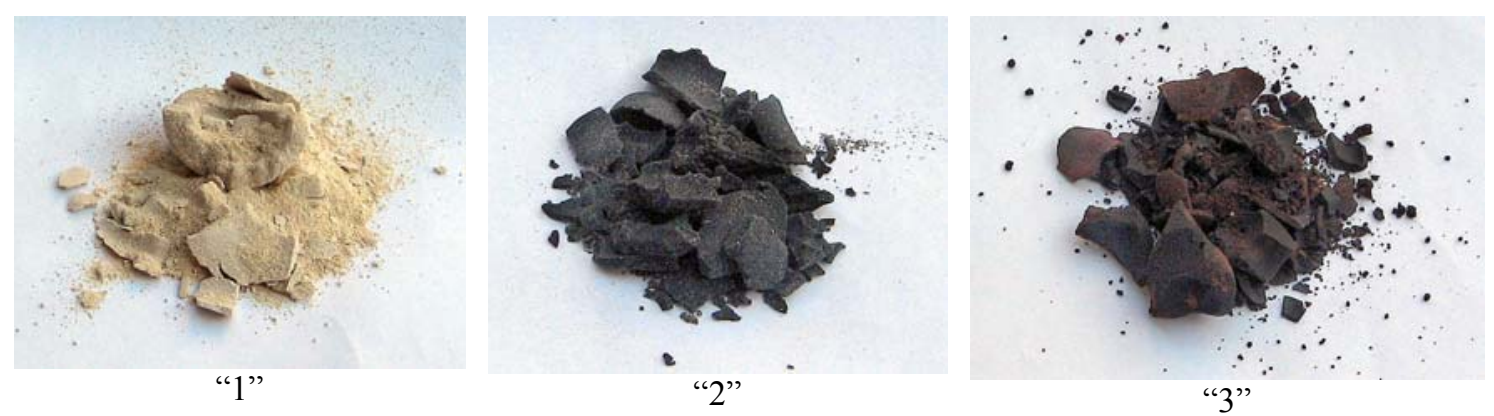

Figura 4.5 - Resíduos sólidos resultantes dos tratamentos “1”, “2” e “3”.

O tratamento "2" por empregar carvão deixa o resíduo com a cor preta e a coloração avermelhada resulta da elevada concentração de ferro no tratamento " 3 " empregando cloreto férrico. 
A disposição destes resíduos deve ser em um aterro industrial, solução porem pouco interessante. Os custos não representam uma barreira e são relacionados no Apêndice E, mas existe uma quantidade mínima de uma tonelada e mesmo no aterro, o resíduo continua sendo de responsabilidade do gerador. A reciclagem é a alternativa que deve ser explorada, no caso do fluido de corte empregado o polialquileno glicol (PAG), o sólido resultante do tratamento pode retornar como insumo para a cadeia de fabricação de "glicóis".

\subsection{Discussão dos Ganhos e Repercussão na Empresa}

A análise dos resultados da intervenção na empresa foi dividida nos seguintes aspectos: ensaios de usinagem em processos de torneamento, nova abordagem para os fluidos de corte e conclusões da empresa sobre a interação.

\subsubsection{Ensaios de Usinagem}

O foco experimental que explora a tecnologia de usinagem torna explícito que este é o diferencial competitivo da empresa. Os negócios devem ser fundamentados pela capacidade de produção com custo reduzido e a diferenciação pela sua qualidade. $\mathrm{O}$ resultado geral proporcionado no conjunto de ações deve referendar a sua posição de mercado.

A discussão dos conceitos, de operações de corte com geometria definida, aborda a importância de explorar a potência e rotação máxima da máquina, evitando as faixas de vibração inadequadas (ressonância) e na formação do cavaco, manter a taxa de remoção sem variações, utilizando o comando no CNC para a manutenção de velocidade de corte $\left(\mathrm{v}_{\mathrm{c}}\right)$ constante.

Os processos devem ser desenvolvidos com critérios sólidos para explorar a produtividade do equipamento, empregando o conhecimento e recursos tecnológicos para viabilizar a máxima produção, com qualidade e redução dos insumos.

Durante a interação é explorada a condição de montagem correta das ferramentas de corte (posição, alinhamento e facilidade para monitorar o estado da aresta de corte) e a importância da rigidez dos sistemas para suportar os regimes de corte em solicitação elevada. A assistência técnica do fabricante dos insumos de produção (insertos e fluido 
de corte) e do comando numérico computadorizado (CNC) proporcionou uma importante contribuição no acompanhamento e desenvolvimento do processo.

Ao diminuir as margens de segurança surgem as fragilidades do processo em desenvolvimento. $\mathrm{O}$ equipamento deve receber maior atenção quando ajustado à nova demanda e a mão de obra, treinada no ciclo de melhoria contínua, deve evoluir tecnicamente e operar com segurança.

$\mathrm{O}$ inserto triangular de aresta aguda proporciona uma nova abordagem para a usinagem. Com capacidade de operar em regimes de potência elevada permite reduzir o tempo de corte e passa a ser adotado em outros processos dentro da empresa.

Ao avaliar os tempos de corte (Apêndice D) é possível a quantificação de todos os tempos que compõe o ciclo de produção de uma peça, evidenciando quais oneram o processo e aqueles que comportam intervenção para um ciclo de menor duração.

$\mathrm{O}$ inserto triangular permite reduzir o custo da peça no item hora máquina e tem pequena influência na composição do custo de insumos. O inserto de corte é a ferramenta que mais onera o processo. Estudos para o emprego ótimo desta ferramenta devem proporcionar ganhos econômicos.

A transparência e rastreabilidade do processo são exigências das normas para as certificações e permitem referendar a tomada de decisão, o registro dos dados viabiliza o controle do sistema para o balanço de entradas e saídas.

O emprego de inserto de corte com largura " $\mathrm{l}_{\mathrm{a}}$ " reduzida conduz à discussão de como operar esta ferramenta e da importância de ter o processo racionalizado. Os ganhos ambientais relativos à redução do consumo de aço são de pequenas proporções e pedem quantificação. Potencializados ao se estenderem por toda a empresa, ou até o parque industrial, funcionam como direcionadores para a cultura de "desmaterialização" da economia e dos produtos de baixo impacto ambiental.

Proporcionados pela redução de $1 \mathrm{~mm}$ (um milímetro) na largura " $\mathrm{l}_{\mathrm{a}}$ " do inserto de corte, os ganhos econômicos são significativos e registrados pela empresa para a peça “Capa Maior” mostram que, em um mês, são poupados $15 \mathrm{Kg}$ de aço (matéria prima). Uma projeção para todos os processos que receberam a alteração é de uma economia de 
$\mathrm{R}$ \$ 5180,00 em um ano, ou $1400 \mathrm{Kg}$ de aço, como descrito no Apêndice F. Este valor representa aproximadamente $0,3 \%$ do faturamento anual da empresa.

\subsubsection{Fluido de Corte}

Ao equilibrar a cadeia de resíduos, com o tratamento e disposição adequada (fase de descarte) do fluido de corte, faz-se necessária a garantia do fabricante de que o tratamento seja uma forma de transformar o resíduo em produtos recicláveis sem riscos de conter substâncias determinadas como tóxicas pelas agências reguladoras.

Com este propósito a empresa em estudo é levada a substituir o produto utilizado em suas máquinas. O fluido adotado, o polialquileno-glicol (PAG), é classificado como de baixo risco à saúde do operador, implicando em ganhos no aspecto social; ao considerar o meio ambiente, é substância pouco agressiva e reciclável.

Os ganhos na produção surpreendem o corpo técnico da empresa que descreve a evolução na usinagem da peça "Pino da Dobradiça". Com a substituição do fluido de corte a vida da aresta é aumentada de aproximadamente seiscentas, para mil peças, em um incremento de $67 \%$ no tempo de serviço da ferramenta registrado com o fluido de corte anterior. A qualidade das superfícies produzidas é superior e o processo torna-se mais previsível.

A substituição do fluido de corte na empresa é resultado relevante deste trabalho conduzindo a uma mudança cultural. A visão sobre da função e desempenho do auxiliar de processo incorpora a capacidade de refrigeração e lubrificação da zona de corte que é relacionada aos ganhos de produtividade e confiabilidade. A manutenção e o monitoramento garantem a sua função, proporcionando melhor desempenho ambiental e a redução de custos.

Durante o período de interação com a empresa são absorvidos os valores do "housekeeping” (boas práticas) refletidos na verificação diária da concentração, medida em "Brix", utilizando o refratômetro, o controle do $\mathrm{pH}$ e a retirada da camada superficial de óleo estranho (contaminante), também é criada uma rotina de manutenção para o controle biológico (microorganismos), aditivação, filtragem e a limpeza periódica do reservatório. 
O emprego do insumo de maneira ótima, com o suporte da assistência técnica e a perspectiva de eliminar o passivo ambiental (fluido de corte descartado) oferecem para a empresa perspectivas de crescimento com transparência e competitividade, com a possibilidade de, num futuro próximo, comprar o serviço de gerenciamento dos fluidos de corte, para concentrar os esforços na área de sua competência, a usinagem.

\subsubsection{Conclusões da empresa}

No encerramento das atividades na empresa foi feita uma entrevista para avaliar os resultados da interação. O responsável técnico apresentou a sua avaliação com os seguintes tópicos:

- Os recursos empregados na produção podem ser melhor aproveitados. Isso inclui desde os equipamentos aos auxiliares de processo e matéria prima.

- Os processos de produção merecem mais atenção, é necessário desenvolver melhor este setor da empresa.

- Investir nos recursos humanos.

Exemplo: treinamento para usar melhor o CNC que equipa as máquinas resulta em mais recursos de produção e maior autonomia aos profissionais na empresa, que ganha em competitividade.

- Exigir mais da assistência técnica para explorar melhor o potencial dos produtos.

Exemplos: O fabricante de ferramentas propôs uma série de sessões de treinamento para a empresa. O fabricante de fluido de corte participa do gerenciamento do fluido na empresa.

\subsection{Projeção de Possibilidades no Parque Industrial}

A prospecção no parque industrial permite diagnosticar alguns focos de atuação que, em escala, tornam-se interessantes para toda a sociedade.

Ao abordar o emprego dos fluidos de corte é possível a transformação da cultura em que está inserido (evidenciado na tabela 4-2). Este auxiliar de processo tem influência significativa no desempenho da usinagem, devendo ser selecionado com o compromisso entre produtividade, o bem estar do operador e os impactos ambientais nas fases de síntese, utilização e descarte. 
Os cuidados relativos à manutenção proporcionam maior tempo de serviço e melhor desempenho no processo, resultando em ganhos de produtividade e economia de recursos. Estas vantagens são potencializadas com a constatação dos riscos de contaminação do solo e dos corpos hídricos através do manejo inadequado.

Uma direção para atingir os objetivos do desenvolvimento sustentável é substituir o comércio de produtos por serviços, o que já é realidade para o fabricante do fluido de corte, que vende o serviço de gerenciamento e conserva a responsabilidade sobre o desempenho em operação e as condições adequadas no descarte. Esta tendência pode ser implementada para um conjunto de pequenas e médias empresas que em cooperação passam a oferecer escala comercial para a sua viabilização. Em uma projeção é possível supor que a assistência técnica, devidamente aparelhada, efetue visitas periódicas às empresas de usinagem, com o suporte de uma base local para a análise, tratamento e distribuição de produtos e resíduos.

A proposta de um núcleo de suporte para, principalmente, a micro e pequena empresa, pode representar um salto de qualidade para o parque industrial, uma mudança de patamar tecnológico, resultando em maior competência, competitividade, além de melhor desempenho ambiental dos processos, serviços e produtos.

Os resultados discutidos neste capítulo evidenciam que, na mudança de paradigmas, pequenas intervenções nos processos de usinagem podem direcionar as empresas para as necessidades futuras. A redução das larguras " $l_{a}$ ”, dos insertos nas operações de corte proporciona ganhos como em um exemplo, nos aspectos que vão da redução de custos de matéria prima à preservação das jazidas de minério, menores volumes para a reciclagem, conseqüente redução de transportes que proporciona economia de combustíveis e a redução de emissões de gases que perturbam o equilíbrio da biosfera.

Como resultado maior observamos que os avanços registrados na empresa estudada podem ser expandidos ao parque industrial, que pode obter suporte para adequar-se ao paradigma de produção desenvolvimento sustentável.A cooperação entre empresas e universidades pode servir como mecanismo indutor das transformações nas pequenas e médias empresas. Os conceitos desenvolvidos nesta pesquisa apresentam potencial para serem aplicados a outros processos e em outras áreas da manufatura. 


\section{CONCLUSÕES}

Ao concluir os trabalhos é possível confirmar a importância de oferecer suporte para a pequena e média empresa (PME) como é enfatizado por (HILLARY, 2004; UNEP, 2003 e WCED, 1987). O envolvimento desta classe de empresas é fundamental para reverter o processo de degradação dos sistemas naturais sobre os quais está estruturada a sociedade industrial.

Em um esforço de transição para o paradigma desenvolvimento sustentável, através da mudança cultural, associada aos avanços científico-tecnológicos, a indústria deve adequar-se às condições de equilíbrio do planeta terra.

Conforme verificado, isto pode ocorrer em um salto de qualidade para o sistema produtivo que ao absorver novos valores, passa a gerar produtos e serviços com maior competência, preservando os recursos e controlando os resíduos que são reabsorvidos como insumos em um ciclo fechado.

Como parte do esforço conjunto de todos os setores da sociedade, são discutidas, determinadas e então verificadas no trabalho de campo as direções para a adequação dos processos de usinagem ao novo paradigma.

Analisando o conjunto de empresas envolvidas no estudo, é possível concluir que existe potencial. Ao oferecer suporte e um contexto favorável, estas empresas podem produzir com maior competência e competitividade, melhor qualidade, empregando recursos de maneira ótima e destinando seus resíduos para novas cadeias de produção.

Os experimentos realizados verificaram a eficácia do modelo proposto. Ao escolher um processo de usinagem, com a proposta de inserir conhecimento e as tecnologias 
acessíveis ao empreendedor, é possível obter ganhos que vão da eficiência econômica a uma melhor condição social e à preservação do meio ambiente.

O processo, tratado como o sistema proposto para o desenvolvimento dos experimentos (Figura 3.1), teve reduzido o consumo de insumos, ganhou produtividade e confiabilidade, com seus resíduos minimizados, tratados e destinados à reciclagem.

A estrutura proposta para o desenvolvimento da interação com as empresas mostrou-se funcional, podendo ser empregada como um modelo para as ações futuras.

A divisão em focos experimentais possibilita a análise detalhada da ação e a sua repercussão nos demais processos da empresa, permitindo multiplicar seu efeito no parque industrial.

\subsection{Primeiro Foco Experimental}

O primeiro foco experimental, abordando a tecnologia de usinagem, permite a inserção dos conceitos para as operações de corte com geometria definida. Ao empregar uma ferramenta de catálogo é possível aumentar o rendimento do processo e torná-lo mais confiável. O corpo técnico da empresa adquire repertório para operar o equipamento com maior competência.

Os ensaios que abordam a substituição do desbaste em vários passes por passe único, utilizando o inserto triangular de aresta aguda, permitem a redução do custo de fabricação com menor tempo de corte e peças produzidas fora das especificações.

Estas conclusões são referendadas quando a empresa adota este tipo de inserto para a fabricação de outras peças.

Ao empregar o inserto com a proposta de reduzir o tempo de corte e conseqüentemente a duração do ciclo de produção de uma peça, o processo é analisado para verificar quais etapas merecem desenvolvimento e a dimensão dos ganhos resultantes com a alteração. Isto proporciona transparência ao processo sendo um ganho relevante para a racionalização dos recursos, fundamental na transição para uma condição de reduções drásticas de consumo e perdas de processo. 


\subsection{Segundo Foco Experimental}

O segundo foco experimental, abordando a economia de recursos, tem em seus resultados dois aspectos técnicos relevantes.

O primeiro aspecto é relativo à operação de uma ferramenta menos robusta, que exige o refinamento da operação, evidenciando as perdas relativas aos modos de segurança que escondem os pontos críticos do processo e as oportunidades de aperfeiçoamento.

O segundo aspecto conduz à interpretação de que é tecnicamente viável a redução do consumo de matéria-prima ao reduzir a largura da ferramenta de corte. No caso estudado os ganhos econômicos justificam o desenvolvimento do processo em função do corte da peça.

A redução do consumo de aço é justificada por custos menores que podem ser revertidos em lucro, mas a proposta deste trabalho é sugerir uma organização social com um sistema econômico menos dependente dos recursos materiais. Em um exercício é possível supor que, ao adotar larguras de corte reduzidas, a indústria como um conjunto pode proporcionar uma significativa redução de impactos ambientais, resultantes das etapas de extração, processamento, transporte e reciclagem dos materiais empregados na produção. Esta possibilidade é de grande interesse na mudança de valores onde produtos e serviços de baixo impacto ambiental recebem um diferencial competitivo no mercado.

\subsection{Terceiro Foco Experimental}

O terceiro foco experimental aborda a regularização da cadeia de resíduos cumprindo o propósito de evidenciar os riscos ambientais do manejo inadequado dos fluidos de corte. Ao propor tratamento e caracterizar seus resultados é possível contribuir para o desempenho ambiental das empresas que incorporam a gestão e gerenciamento do auxiliar de processo em suas fases de uso e descarte.

O gerenciamento do fluido de corte resulta em maior produtividade e qualidade na usinagem com a redução de seu consumo e a geração de resíduos classificados pela legislação como perigosos. 


\subsection{A Interação na Empresa}

$\mathrm{Na}$ empresa, a interação proporcionou condição de respaldo para o investimento na otimização dos recursos, em aprimoramento no desenvolvimento dos processos, no treinamento do corpo técnico e fortalecimento das parcerias com seus fornecedores.

É possível concluir que ocorreu um salto de qualidade com o direcionamento para a capacidade da empresa de agregar valor no desenvolvimento do processo e execução da peça. A injeção de tecnologia e conhecimento leva motivação para a equipe, que ganha solidez.

Ao equilibrar a cadeia de resíduos, o suporte ao equacionamento dos impasses, no processo de tomada de decisão, permite ao pequeno empreendedor conservar o foco no negócio e disponibilidade para administrar o futuro da empresa. Com melhor desempenho ambiental, a empresa absorve um diferencial competitivo, que já é parte da estratégia empregada para o seu crescimento.

\subsection{O Parque Industrial}

Durante os trabalhos é registrado potencial no parque industrial para absorver novos valores. No entanto existe a carência de elementos motivadores para a mudança de cultura das empresas envolvidas no estudo.

Ao propor um salto de qualidade a estas empresas é possível implementar os aspectos abordados nos experimentos através de ações pontuais.

Embora ainda não quantificados, os ganhos para as implementações propostas aos processos de usinagem, em um conjunto de empresas, oferecem as condições exigidas para o início da mudança de paradigma.

Multiplicados os efeitos de maior eficiência econômica, com respeito ao ser humano e seu meio ambiente, tendem a transformar o parque, e suas indústrias, em referência no percurso a uma era de harmonização do sistema produtivo com os ciclos naturais do nosso planeta. 


\subsection{Avaliação Final}

A simulação, através de modelos, das operações de corte e da formação do cavaco, o monitoramento (em tempo real) da qualidade com que está sendo produzida a superfície usinada, a gestão de insumos e resíduos segundo preceitos da ecologia industrial, como alguns exemplos de tecnologias que viabilizarão o novo paradigma de produção, ainda estão restritos aos centros de pesquisas.

Cabe observar que a interação entre universidade e empresa oferece excelentes resultados, sendo uma forma de referendar o conhecimento desenvolvido para alinhar-se aos interesses da sociedade.

Com este trabalho foi possível constatar a situação dos processos de usinagem na pequena e média empresa de São Carlos e oferecer uma contribuição entendendo que a excelência pode ser atingida com poucos subsídios.

\subsection{Sugestões Para Trabalhos Futuros}

Este trabalho gerou questionamentos que devem ser investigados em trabalhos futuros.

- Aplicar as alterações de processos propostas neste trabalho em um grupo de empresas e quantificar os ganhos resultantes.

- Quantificar os ganhos ambientais da redução de consumo de aço resultante da substituição de largura "l $\mathrm{a}$ " do inserto de corte.

- Quantificar os impactos ambientais dos processos de usinagem.

- Padronizar procedimentos para a realização de ensaios de usinagem nas instalações das empresas.

- Desenvolver o tratamento do fluido de corte na fase de descarte para sua realização nas empresas. 


\section{REFERÊNCIAS}

AGENDA 21 (1992). Cúpula da terra: conferência das nações unidas sobre meio ambiente e desenvolvimento. Rio de Janeiro: Centro de Informação das Nações Unidas. Disponível em: $<$ http://www.mma.gov.br/index.cfm?id_estrutura=18>. Acesso em: 20 nov. 2005.

AGENDA OF SCIENCE FOR ENVIRONMENT INTO THE 21st CENTURY (1994). Vienna conference. New York: Cambridge University Press.

ALVES, S. M. (2005). Adequação ambiental do processo de retificação através de um novo conceito de fluido de corte. 185p. Tese (Doutorado) - Escola de Engenharia de São Carlos, Universidade de São Paulo, São Carlos, 2005.

ASSOCIAÇÃO BRASILEIRA DE NORMAS TÉCNICAS (1986). NBR 10.004: Resíduos sólidos: classificação. 2.ed. Rio de Janeiro.

. (1989). NBR 6162: Movimentos e relações geométricas na usinagem dos metais. Rio de Janeiro.

. (1996). NBR ISO 14.001: Sistemas de gestão ambiental: especificação e diretrizes para uso. Rio de Janeiro.

BOOTHROYD, G.; KNIGHT, W. A. (1989). Fundamentals of machining and machine tools. $2^{\text {nd }}$ ed. New York: Marcel Dekker.

BRAGHINI JUNIOR, A. (2002). Metodologia para escolha de fluidos de corte não agressivos ao meio ambiente para aplicações em usinagem de metais. 230p. Tese (Doutorado) - Escola de Engenharia de São Carlos, Universidade de São Paulo, São Carlos, 2002.

BYRNE, G.; DORNFELD, D.; DENKENA, B. (2003). Advancing cutting technology. Paris: CIRP. Keynote.

BYRNE, G.; SCHOLTA, E. (1993). Environmentally clean machining processes - a strategic approach. CIRP Annalen, Paris, v.42, n.1, p.471-474. 
CAPRA, F. (2003). Life and leadership: a systems approach. Management seminars. Disponível em:<http://www.fritjofcapra.net/summary.html>. Acesso em: 2 Mar. 2003.

CAREY, A. (2004). Global warming; consensus is growing among scientists, governments, and business that they must act fast to combat climate change. This has already sparked efforts to limit $\mathrm{CO} 2$ emissions. Many companies are now preparing for a carbon-constrained world. Business Week, New York, n.3896, p.60-69, Aug.

CONSELHO NACIONAL DA INDUSTRIA (2002). Indústria sustentável: rio+10 balanço e perspectivas. Brasília. Disponível

em: $<$ http://www.cni.org.br/produtos/meio_amb/ind_sustentavel.htm>. Acesso em: 20 jun. 2004.

DeGARMO, E. P. (1957). Materials and processes in manufacturing. New York: MacMillan.

DROY, B. F.; RANDLES, S.J. (1999). Environmental impact. In: RUDNICK, L. R.; SHUBKIN, R. L. Synthetic lubricants and high performance functional fluids. $2^{\text {nd }}$ ed. New York: Marcel Dekker. p. 793-805.

EL BARADIE, M. A. (1996a). Cutting fluids: part I - characterization. Journal of Materials Processing Technology, Amsterdam, v.56, n.1/4, p.786-797, Jan

. (1996b). Cutting fluids: part II - recycling and clean machining. Journal of Materials Processing Technology, Amsterdam, v.56, n.1/4, p.798-806, Jan.

FERRARESI, D. (1985). Fundamentos da usinagem dos metais. São Paulo: Edgard Blucher.

FURTADO, C. (1974). O mito do desenvolvimento econômico. Rio de Janeiro: Paz e Terra.

Cultural. . (1983). Teoria e política do desenvolvimento econômico. São Paulo: Abril

GRAEDEL, T. E.; ALLENBY, B.R. (1995). Industrial ecology. New Jersey: Prentice Hall. 
GRÜBLER, A. (1994). Industrialization as a historical phenomenon. In: SOCOLOW, R. et al. Industrial ecology and global change. Cambridge: University Press.

HART, S.L.; MILSTEIN, M.B. (2004). Criando valor sustentável. RAE Executivo, São Paulo, v.3, n.2, p.65-79, maio/jun.

HENDERSON, H. (1991). Transcendendo a economia. São Paulo: Cultrix.

HILLARY, R. (2004). Environmental management systems and the smaller enterprise. Journal of Cleaner Production, Amsterdam, v.12, n.6, p.561-569, Aug.

KALPAKJIAN, S. (1992). Manufacturing processes for engineering materials. New York: Addison-Wesley.

KLOCKE, F.; EISENBLAETTER, G. (1997). Dry cutting. CIRP Annalen, Paris, v.42, n.2, p.519-526.

KUHN, T.S. (1996). Estrutura das revoluções cientificas. 4.ed. São Paulo: Perspectiva.

LEITE, W.C.A. (1997). Estudo da gestao de resíduos sólidos: uma proposta de modelo tomando a unidade de gerenciamento de recursos hídricos (UGRHI-5) como referencia. 270p. Tese (Doutorado) - Escola de Engenharia de São Carlos, Universidade de São Paulo, São Carlos, 1997.

MACHADO, A.R.; SILVA, M.B. (2004). Usinagem dos metais. Uberlância: Laboratório de Ensino e Pesquisa em Usinagem, Universidade Federal de Uberlândia. Apostila.

MAGNANI, M. (2000). Abordagem integrada de aspectos conceituais relacionados à adequação ambiental em manufatura. 123p. Tese (Mestrado) - Escola de Engenharia de São Carlos, Universidade de São Paulo, São Carlos, 2000.

MANG, T.; DRESEL, W. (2001). Lubricants and lubrication. Germany: Wiley$\mathrm{VCH}$.

MANZINI, E.; VEZZOLI, C. (2002). O desenvolvimento de produtos sustentáveis. São Paulo: EDUSP. 
. (2003). A strategic design approach to develop sustainable product service systems: examples taken from the 'environmentally friendly innovation' Italian prize. Journal of Cleaner Production, Amsterdam, v.11, n.8, p.851-857, Dec. Disponível em: $<$ www.elsevier.com/locate/jclepro>. Acesso em: 20 July 2004.

MARTIN, R.S.; MILLER, R.G. (1967). Iniciação ao estudo da economia. Rio de Janeiro: Zahar.

MOTA, S. (2000). Introdução à engenharia ambiental. Rio de Janeiro: ABES.

NACHTMAN, E.S. (1989). Metal cutting and grinding fluids. In: AMERICAN SOCIETY FOR METALS HANDBOOK. Metals handbook. $9^{\text {th }}$ ed. Metals Park. v.16.

ODUM, H.T. (1971). Environment, power, and society. New York: WileyInterscience.

PEARCE, D.; MARKANDYA, A.; BARBIER, B. (1996). Blueprint for a green economy. London: Earthscan.

QUEIROZ, J.L.L.; BOEHS, L.; SANT’ANNA, F. (1999). Proposta para aprimorar o manejo dos fluidos de corte. Máquinas e Metais, São Paulo, ano 35, n.399, p.250-255.

RODRIGUES, A.R. (2005). Estudo da geometria de arestas de corte aplicadas em usinagem com altas velocidades de corte. $227 \mathrm{p}$. Tese (Doutorado) - Escola de Engenharia de São Carlos, Universidade de São Paulo, São Carlos, 2005.

ROTHER, M.; SHOOK, J. (1999). Aprendendo a enxergar. São Paulo: Lean Institute Brasil.

SACHS, I. (2002). Caminhos para o desenvolvimento sustentável. Rio de Janeiro: Garamond.

SANDVIK COROMANT (2000). Steel turning. Suécia. 1 CD-ROM.

SANDVIK COROMANT (2002). Ferramentas para torneamento. Suécia: Elanders. Catálogo. 
SANTOS, C. (2005). Prevenção à poluição industrial: identificação de oportunidades, análise dos benefícios e barreiras. 287p. Tese (Doutorado) - Escola de Engenharia de São Carlos, Universidade de São Paulo, São Carlos, 2005.

SANTOS, L.G. (2003). Politizar as novas tecnologias. São Paulo: Ed.34.

SANTOS, M.F. (1999). Por uma sociedade conservacionista: idéias e expoentes da conservação da natureza no Brasil. 255p. Tese (Doutorado) - Escola de Engenharia de São Carlos, Universidade de São Paulo, São Carlos, 1999.

SCHONBERGER, R.J. (1984). Técnicas industriais japonesas: nove lições ocultas sobre simplicidade. São Paulo: Pioneira.

SERVIÇO BRASILEIRO DE APOIO ÀS MICROS E PEQUENAS EMPRESAS (2005a). Boletim estatístico de micro e pequenas empresas. Observatório SEBRAE. Disponível em: $<$ http://www.sebrae.com.br/br/mpe numeros/>. Acesso em: 18 out. 2005.

. (2005b). Legislação básica da micro e pequena empresa. Portal Sebrae. Disponível em: $<$ http://www.sebrae.com.br/br/aprendasebrae/estudosepesquisas.asp $>$. Acesso em: 18 out. 2005.

SELIGER, G. (2004). Global sustainability a future scenario. In: GLOBAL CONFERENCE ON SUSTAINABLE PRODUCT DEVELOPMENT AND LIFE CYCLE ENGINEERING, 2004, Berlin. Proceedings... Berlin: Uni-edition. p.29-35.

SOUZA, M.P. (2000). Instrumentos de gestão ambiental: fundamentos e prática. São Carlos: Riani Costa.

THOREAU, H.D. (1984). Walden a vida nos bosques. 2.ed. São Paulo: Global.

TOMA, H.E. (2004). O mundo nanométrico: a dimensão do novo século. São Paulo: Oficina de Textos.

TRENT, E.M. (1996). Metal cutting. Oxford: Butterworth Heinemann.

TRENT, E.M.; WRIGHT, P. K. (2000). Metal cutting. $4^{\text {th }}$ ed. Boston: Butterworth Heinemann. 
UNITED NATIONS ENVIRONMENT PROGRAM (2003). Big challenge for small business: sustainability and SMEs. Industry and Environment, Paris, v.26, n.4, p.4-6, Oct./Dez. Disponível em: $<$ www.uneptie.org/media/review/ie_home.htm $>$. Acesso em: 25 Aug. 2004.

UNITED NATIONS ENVIRONMENT PROGRAM INDUSTRY AND

ENVIRONMENT (1996). Cleaner production: a training resource package. Paris:

United Nations Publication.

WALTER, A. (2005). Refrigerantes usados com eficiência. Máquinas e Metais, São Paulo, ano 49, n.476, p.250-255.

WANIGARATHNE, P.C. et al. (2004). Assesment of process sustainability for product manufacture in machining operations. In: GLOBAL CONFERENCE ON SUSTAINABLE PRODUCT DEVELOPMENT AND LIFE CYCLE ENGINEERING, 2004, Berlin. Proceedings... Berlin: Uni-edition. p.305-312.

WORLD COMMISSION ON ENVIRONMENT AND DEVELOPMENT (1987). Our common future. New York: Oxford University Press. 


\section{APÊNDICE A - QUESTIONÁRIOS}

Questionário 1 - Dados da Empresa

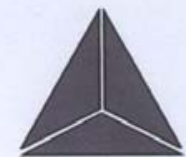

NUMA
USP - São Carlos

Núcleo de Manufatura Avançada

Grupo de Otimização de Processos de Fabricação

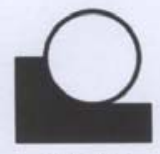

OPF

\section{Trabalho de Campo}

Avaliação do Nível Tecnológico em Empresas de Usinagem em São Carlos

1.0 Informações sobre a empresa

Razão Social

Ramo/produtos

Porte - nro funcionários -faturamento anual

Segmento de mercado - clientes - escala

Parque Fabril - breve descrição

Recebe assistência técnica?

Possui máquinas sofisticadas?

Emprega ferramentas sofisticadas?

Qualificação da mão de obra

Nro de engenheiros:

Nro de Tec. Mecânico:

Responsável técnico

Cargo que ocupa

Estudante Responsável : Tobias Heymeyer

Estudante Responsável : Tobias Heymeyer
Professor Responsável: Prof. Dr. Joầ F. Gomes de Oliveira Professor Responsavel: Prof. Dr. Joåo F. Gomes de Oliveira
Av. Trabalhador Săo-carlense, 400 - $13566-590$ - Såo Carlos - SP Fone/Fax: (0xx16) 273-9438 e-mail : th@asc.usp.br
For 
Questionário 2 - Materiais e Operações

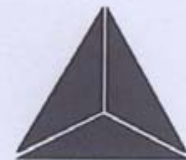

NUMA
USP - São Carlos

Núcleo de Manufatura Avançada

Grupo de Otimização de Processos de Fabricação

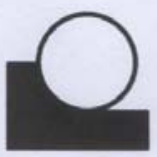

OPF

\section{Trabalho de Campo}

\section{Avaliação do Nível Tecnológico em Empresas de Usinagem em São Carlos}

Grupo 1

Materiais e Operações

- Material usinado

- Operações de corte

- Parâmetros de corte : - rotação de trabalho

- profundidade de usinagem

- velocidade de corte

- velocidade de avanço

- tempo de usinagem

- tempo de set up

\section{0 - Grupo 2 Máquina Operatriz}

- Máquina ferramenta convencional

- Máquina automática mecânica

- Máquina automática hidraulica

- Máquina com comando numérico

- Máquina especial / dedicada

Condiçōes de Trabalho

-Folha de processo

- Critérios de determinação das condiçø̃es de trabalho

Dados da Máquina

- Rotações possíveis

- Potência do motor

- Rigidez

- Ano de fabricação

Marca / modelo

Estudante Responsável : Tobias Heymeyer

Professor Responsável: Prof. Dr. João F. Gomes de Oliveira

Av. Trabalhador São-carlense, 400 - 13566-590 - São Carlos - SP

Fone/Fax: (0xx16) 273-9438 e-mail : th@sc.usp.br 
Questionário 3 - Ferramentas e Fluidos

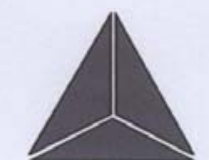

NUMA

\section{USP - São Carlos}

Núcleo de Manufatura Avançada

Grupo de Otimização de Processos de Fabricação

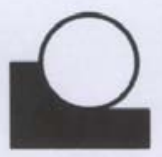

OPF

\section{Trabalho de Campo}

Avaliação do Nível Tecnológico em Empresas de Usinagem em São Carlos

- Grupo 3 Ferramentas de Corte

Tipo de Ferramenta - Aço Rápido, Metal Duro soldado, Insertos, Insertos recobertos, PCBN, Diamante

Afiação de ferramentas

Custos / ano com ferramentas na operação

Disponibilidade de suportes

- Grupo 4 Fluído de Corte

Tipos de fluidos empregados

Forma de aplicação - vazão/ intermitente

Técnicas tipo MQL

Refrigeração em operações distintas

Armazenamento

Filtragem

Aditivação

Critérios de descarte

Disposição final 


\section{APÊNDICE B - ENSAIOS DE USINAGEM}

Desenho técnico da peça usinada no ensaio.

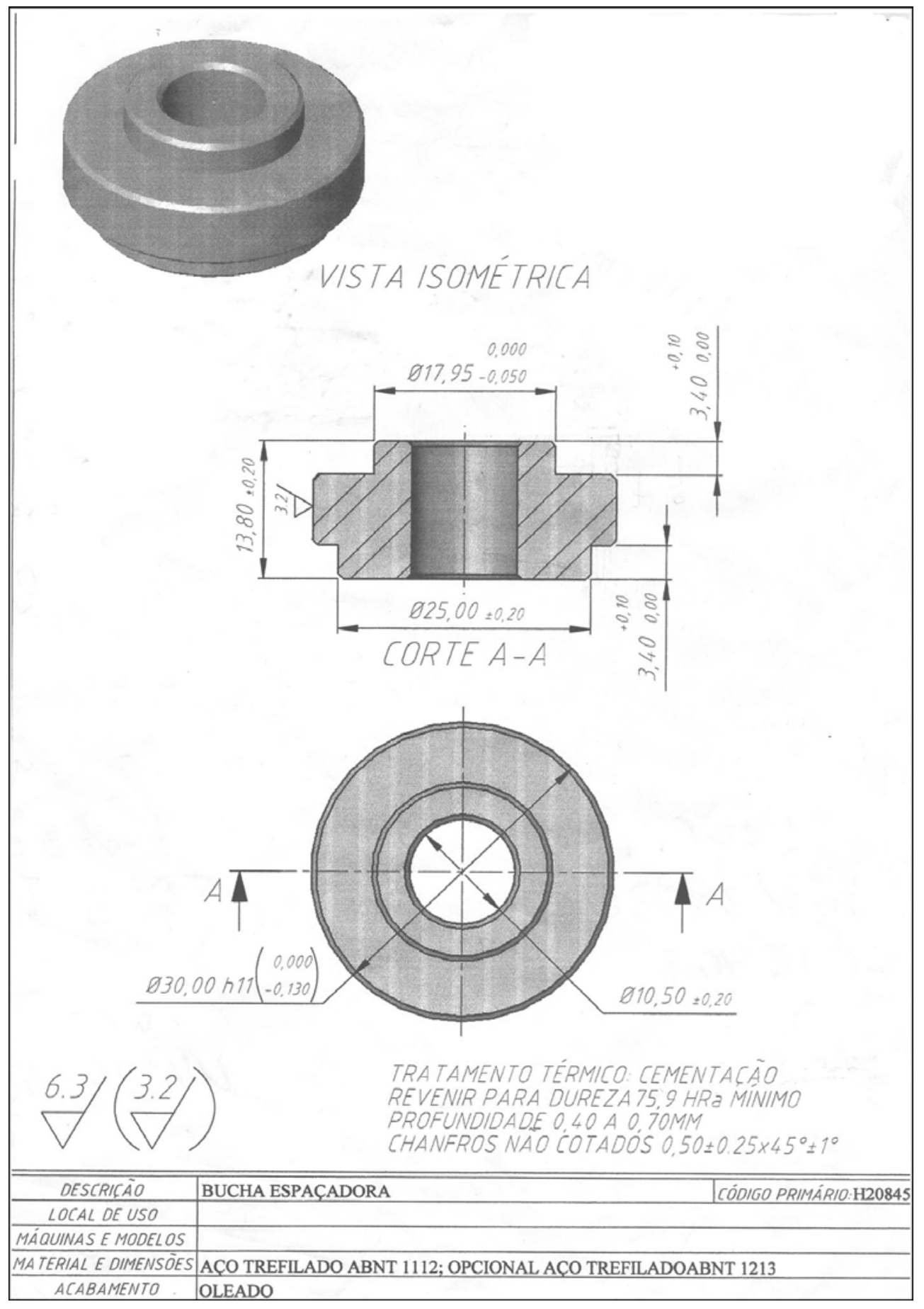


120

Folha de processos elaborada para os ensaios.

Folha de Processo

Ensaio I

1: Operasão furar $\varnothing 10,5 \mathrm{~mm}$

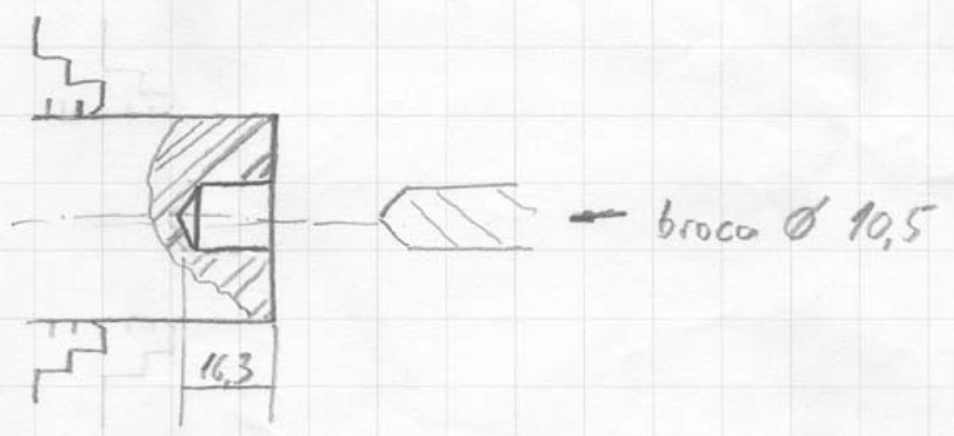

2: Operasció desbeste

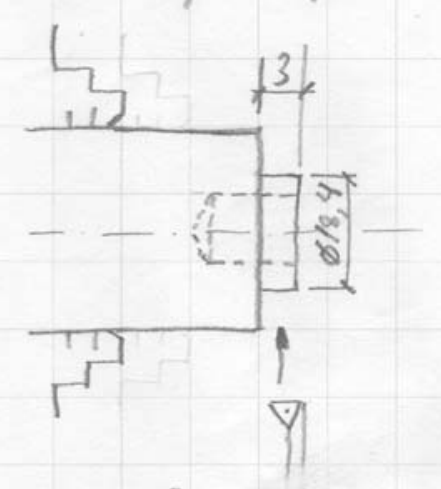

passo único ap $=3 \mathrm{~mm}$

$V_{c}=141 \rightarrow 198 \mathrm{~m} / \mathrm{m} / \mathrm{n}$

$f=0,15 \rightarrow 0,25 \mathrm{~mm} /$ rot

3: Operagño Acubamento todo perfol

ferramenta WNMG

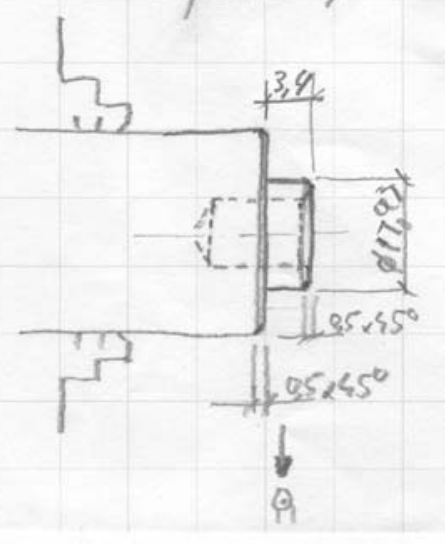

1: facear ap $=0,05 \mathrm{~mm}$

2 - changtrar $0,5 \times 4,5^{\circ}$

3 : cildudiar $\varnothing 17,43 \pm 0,03$

4. facear ap $=0,4 \quad L=3,4 \mathrm{~mm}$

$5^{\circ}$ chamfrar $0,5 \times 45^{\circ}$ 
4: Operagä́ cunal $\varnothing 25 \times 3,4 \mathrm{mem}$

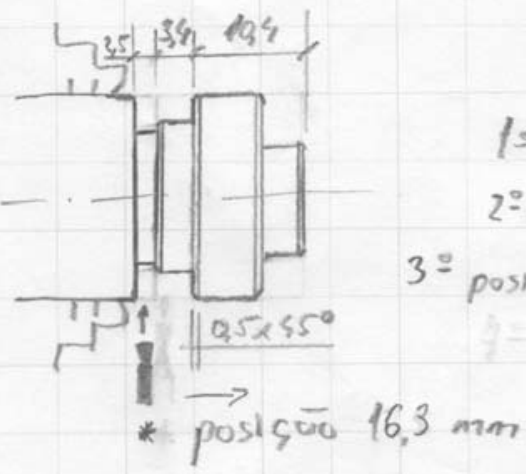

ferramenta bechane 3,5 anm

to ha posigcie $16,3 \mathrm{~mm}$ canal $\varnothing 24 \times 2,5 \mathrm{~mm}$ $2^{\circ}$ na posigä $12,4 \mathrm{~mm}$ chanfrar $0,5 \times 45^{\circ}$ - posigáo 129.m canal $\varnothing 25 \times 2,5$ mm cilindiar $\varnothing 25 \times 3,4 \mathrm{~mm}$ posiçü 16,3 mm

$4=$ na posisáo $15,8 \mathrm{~mm}$ chanfrar $0,5 \times 45^{\circ}$

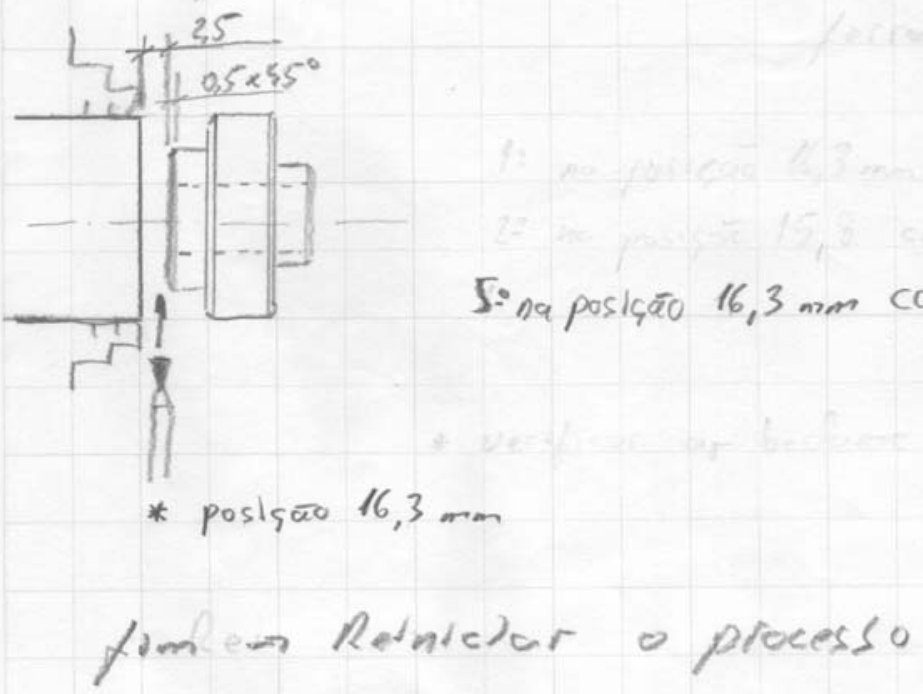




\section{Programa Ensaio I}

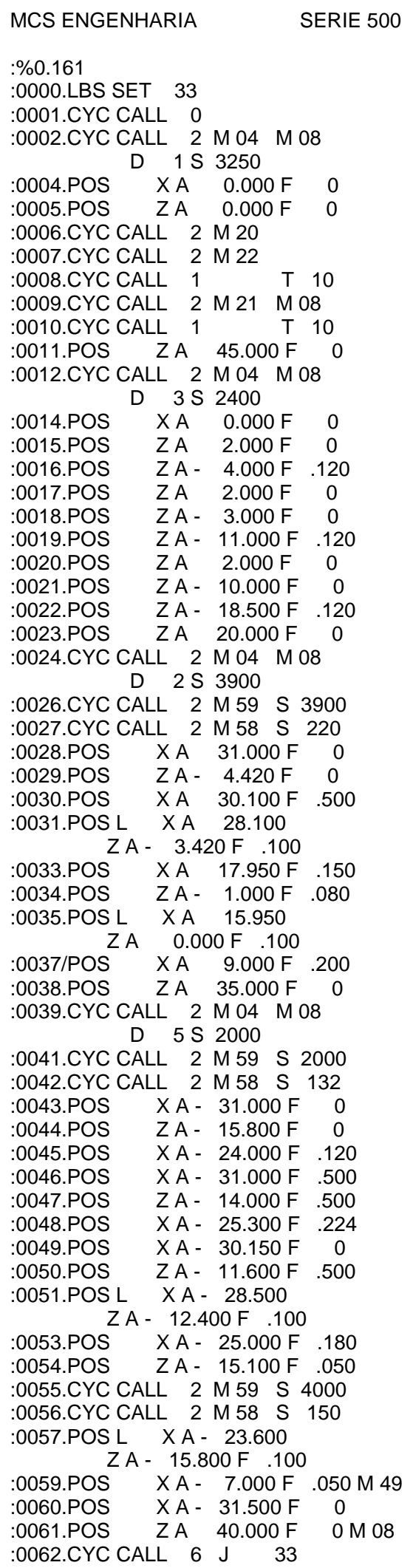




\section{Programa Ensaio II}

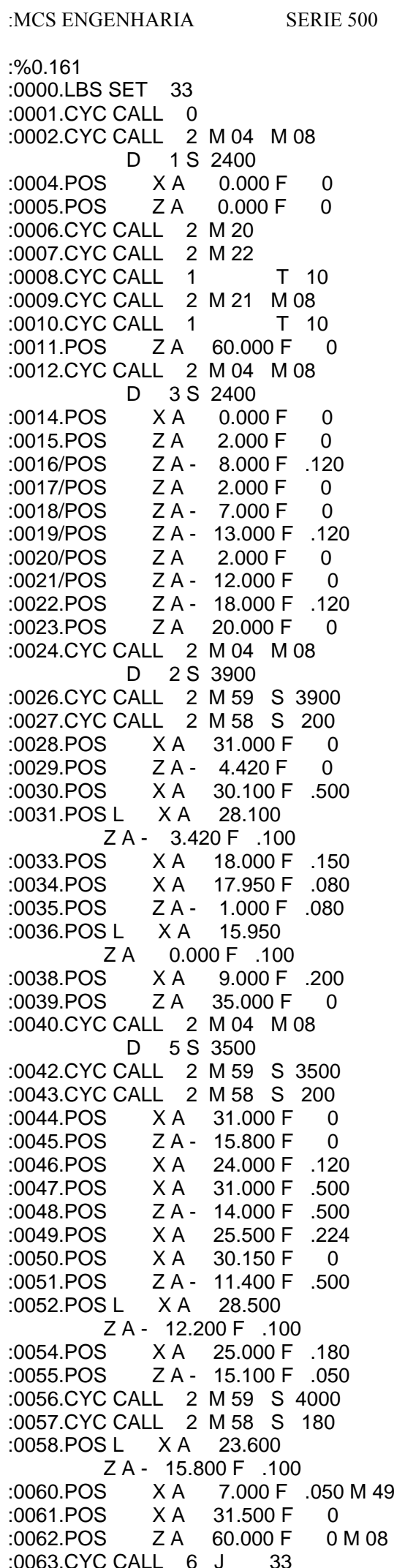




\section{APÊNDICE C - DIÁRIO DE CAMPO}

Os ensaios foram conduzidos na empresa respeitando as prioridades de produção, sendo executados em duas fases.

\section{Fase I - Início 12-07-2005}

$1^{\circ}$ dia período das $14: 30$ até $16: 30$ horas

-Discussão do processo segundo folha de processo (em anexos), acertar o programa do $\mathrm{CNC}$ e set-up da máquina com ferramentas do fabricante A.

$2^{\circ}$ dia período das 9:30 - 11:30

-Set-up da máquina, bedame vibra excessivamente em todas as operações e requer novo alinhamento.

-A ferramenta WMNG com função de acabamento não satisfaz as exigências do processo.

- A ferramenta TNMG tem desempenho excelente.

período das 14:30 - 17:00

-No local de ensaio, com o auxílio de um dos pesquisadores do laboratório OPF, discussão das condições de alinhamento do bedame, que examinado com a lupa apresentava sinais de desgaste lateral.

- Durante a operação verifica-se nível menor de vibração mas ainda inaceitável, verifica-se também que a ferramenta WMNG tem desempenho inadequado.

Conclusão: Ao exigir melhor desempenho nas operações de corte a fixação das ferramentas e o controle de vibrações em todo o sistema é fator determinante.

*observação: rotação máxima 3000 rpm.

$3^{\circ}$ dia período das 8:00 - 12:00

-Discussão do processo, eliminar a ferramenta WMNG, reduzir percurso do carro porta ferramentas (passeio da gang).

-Set-up da máquina, após cuidadoso alinhamento vibração inaceitável do bedame.

-Substituição do bedame, espessura $2 \mathrm{~mm}$, fabricante B (sugestão do operador). Resultado positivo, vibrações eliminadas e bom acabamento das superfícies usinadas.

período das 15:00 - 17:00

-No local de ensaio, com o auxílio de dois dos pesquisadores do laboratório OPF, discussão da qualidade das superfícies usinadas, ajuste dos parâmetros de corte e aumento da rotação máxima para $3500 \mathrm{rpm}$.

-Preparação para teste de produção durante o turno de trabalho da noite.

$4^{\circ}$ dia período das 8:30 - 11:30

-Avaliação da produção e estado das ferrametas.

-Avaliação de parâmetros de corte ótimos e redução do tempo de produção da peça. -Avaliação das condições de alimentação com barras de comprimento superior a $0,8 \mathrm{~m}$. -Operação atingindo a rotação máxima da máquina, 4000 rpm. 
Fase I

Avaliação das ferramentas

- A ferramenta TNMG usinou 307 peças com uma aresta de corte, que em inspeção visual com lupa, apresenta sinais de desgaste leve, o operador sugere capacidade para 600 peças, o acabamento da superfície usinada é bom mas percebe-se que a qualidade tende a declinar.

-O bedame usinou 291 peças apresentando pequeno desgaste de flanco ao ser examinado com a lupa, o operador sugere capacidade para 450 peças, o acabamento da superfície usinada é regular.

Fase I - Final 15-07-2005

\section{Fase II - Início 09-08-2005}

$1^{\circ}$ dia período das 9:30 até 11:30 horas

-Set-up da máquina, alinhamento criterioso de todas as ferramentas, os blocos sobre os quais são montados os porta inserto, não oferecem bom apoio sendo empregados calços para alinhamento e fixação adequados.

-O processo desenvolvido nos ensaios da Fase I recebe alteração, a superfície usinada com a ferramenta de desbaste passa a ser cilindramento e a ferramenta é do fabricante $\mathrm{C}$ (sugestão proprietário).

período das 14:00 - 17:00

-Em operação o bedame de $2 \mathrm{~mm}$ do fabricante A, tem bom desempenho, a ferramenta de desbaste produz cavaco fita, inadequado para a produção, esta condição se manteve com a variação dos parâmetros de corte.

$2^{\circ}$ dia período das 9:00 - 11:30

-Set-up da máquina com o bedame de $2 \mathrm{~mm}$ do fabricante A e a ferramenta de desbaste TNMG do mesmo fabricante no processo desenvolvido nos ensaios da Fase I.

-Em operação o desempenho das ferramentas é aprovado produzindo peças com boa qualidade superficial. Os parâmetros de corte são alterados para reduzir o tempo de ciclo, sem alteração significativa das superfícies usinadas.

-A alimentação e feita progressivamente com barras de comprimento: 0,80 m, 1,60 m e finalmente a barra inteira com 3,00 m, comprovando que é possível usinar em rotações de até 4000 rpm com barras longas.

-Buscando a redução do tempo de ciclo a alimentação, momento em que a pinça abre, passa a ser feita sem parar o eixo árvore (alimentar girando).

período das 14:00 - 16:40

-Durante a produção a ferramenta de desbaste TNMG produz superfícies com variação dimensional requerendo grande atenção no controle da produção com algumas peças produzidas fora da tolerância de $0.05 \mathrm{~mm}$.

-O processo instável não pôde ser corrigido através da variação dos parâmetros de corte. Os apertos das fixações verificados e através de inspeção visual, o desgaste da aresta de corte considerado pequeno. 
período das 16:40 - 18:00

-Mudança de operador, o número de peças perdidas (mortas) passa a preocupar, em uma seqüência de dez peças produzidas, três tinham a dimensão fora da tolerância e deveriam ser descartadas.

-O bedame apresenta bom desempenho, com o intuito de verificar a duração da vida de sua aresta de corte, decide-se com sucesso, substituir a aresta da ferramenta de desbaste TNMG, para eliminar as perdas e a irregularidade na produção.

período das 18:00 - 22:15

-Durante o turno da noite os dados são relatados pelo operador.

-A ferramenta de desbaste TNMG apresenta bom desempenho (nenhuma peça perdida) e a produção fica regularizada.

-O bedame quebra e danifica o suporte encerrando a produção.

Fase II

Avaliação das ferramentas

- A ferramenta TNMG usinou 249 peças com uma aresta de corte, substituída por produção irregular, em inspeção visual com lupa, apresenta sinais de desgaste leve. A segunda aresta apresentou bom desempenho usinando 223 peças até o fim do ensaio.

-O bedame usinou 472 peças e tem falha catastrófica, o acabamento das superfícies usinadas, indica que a aresta pré-colapso estava defeituosa.

Fase II - Final 10-08-2005 


\section{APÊNDICE D - DESEMPENHO DAS FERRAMENTAS}

\section{Cálculo do tempo de corte}

Fórmulas adotadas do catálogo Ferramentas para Torneamento Sandvik

$\mathrm{t}_{\mathrm{c}}=$ tempo de corte $[\mathrm{s}]$

$\mathrm{v}_{\mathrm{c}}=$ velocidade de corte $[\mathrm{m} / \mathrm{s}]$

$\mathrm{SCL}=$ comprimento de corte helicoidal $[\mathrm{m}]$

$\mathrm{D}_{\mathrm{m}}=$ diâmetro usinado[mm]

$1_{\mathrm{m}}=$ comprimento usinado $[\mathrm{mm}]$

$\mathrm{f}=$ avanço por rotação[mm/rot $]$

$\mathrm{t}_{\mathrm{c}}=\mathrm{SCL} / \mathrm{v}_{\mathrm{c}}$

operação de faceamento: $\mathrm{SCL}=\left(\left(\mathrm{D}_{\mathrm{m} 1}+\mathrm{D}_{\mathrm{m} 2}\right) / 2 \times \pi / 1000\right) \times 1_{\mathrm{m}} / \mathrm{f}$

operação de cilindramento: $\mathrm{SCL}=\left(\mathrm{D}_{\mathrm{m}} \times \pi\right) / 1000 \times 1_{\mathrm{m}} / \mathrm{f}$

operação de torneamento cônico: $\mathrm{SCL}=\left(\left(\mathrm{D}_{\mathrm{m} 1}+\mathrm{D}_{\mathrm{m} 2}\right) / 2 \times \pi / 1000\right) \times 1_{\mathrm{m} 2} / \mathrm{f}$

$1_{\mathrm{m} 2}=\sqrt{(\operatorname{lm})^{2}+\left(\frac{\mathrm{Dm} 1-\mathrm{Dm} 2}{2}\right)^{2}}$

Ensaio Fase I

Inserto Triangular de Aresta Aguda para Facear "Fabricante A".

Velocidade de corte: $220 \mathrm{~m} / \mathrm{min}=3,67 \mathrm{~m} / \mathrm{s}$

$1^{\mathrm{a}}$ operação: chanfrar diâm $30,00 \mathrm{~mm} \rightarrow \mathrm{SCL}=0,655 \mathrm{~m} \rightarrow \mathrm{t}_{\mathrm{c}}=0,1787 \mathrm{~s}$

$2^{\mathrm{a}}$ operação: facear até diâm $17,95 \mathrm{~mm} \rightarrow \mathrm{SCL}=2,716 \mathrm{~m} \rightarrow \mathrm{t}_{\mathrm{c}}=0,7408 \mathrm{~s}$

$3^{\mathrm{a}}$ operação: cilindrar diâm $17,95 \mathrm{~mm} \rightarrow \mathrm{SCL}=2,044 \mathrm{~m} \rightarrow \mathrm{t}_{\mathrm{c}}=0,5575 \mathrm{~s}$

$4^{\mathrm{a}}$ operação: chanfrar diâm $17,95 \mathrm{~mm} \rightarrow \mathrm{SCL}=0,3876 \mathrm{~m} \rightarrow \mathrm{t}_{\mathrm{c}}=0,1057 \mathrm{~s}$

$5^{\mathrm{a}}$ operação: facear até diâm $10,50 \mathrm{~mm} \rightarrow \mathrm{SCL}=0,6953 \mathrm{~m} \rightarrow \mathrm{t}_{\mathrm{c}}=0,1896 \mathrm{~s}$

Tempo de corte para uma peça: $1,7723 \mathrm{~s}$ 
Estado da aresta "1": bom

Desgaste: inferior a $0,1 \mathrm{~mm}$

Duração do Ensaio I: 307 peças ou 9,07 minutos

Custo do inserto com 6 arestas: $\mathrm{R} \$ 32,81$

Custo por peça usinada: $\mathrm{R} \$ 0,0178$

Segundo o catálogo do fabricante:

Expectativa de vida mínima: 15 min ou 507 peças $\rightarrow$ custo por peça: R\$ 0,0108

Expectativa de vida máxima: 40 min ou 1354 peças $\rightarrow$ custo por peça:R $\$ 0,0040$

\section{Ensaio Fase II}

Inserto Triangular de Aresta Aguda para Facear "Fabricante A"

Velocidade de corte: $200 \mathrm{~m} / \mathrm{min}=3,33 \mathrm{~m} / \mathrm{s}$

$1^{a}$ operação: chanfrar diâm 30,00 $\mathrm{mm} \rightarrow \mathrm{SCL}=0,655 \mathrm{~m} \rightarrow \mathrm{t}_{\mathrm{c}}=0,1966 \mathrm{~s}$

$2^{\mathrm{a}}$ operação: facear até diâm $18,00 \mathrm{~mm} \rightarrow \mathrm{SCL}=2,707 \mathrm{~m} \rightarrow \mathrm{t}_{\mathrm{c}}=0,8121 \mathrm{~s}$

$3^{\mathrm{a}}$ operação: facear até diâm $17,95 \mathrm{~mm} \rightarrow \mathrm{SCL}=0,0176 \mathrm{~m} \rightarrow \mathrm{t}_{\mathrm{c}}=0,0053 \mathrm{~s}$

$4^{a}$ operação: cilindrar diâm 17,95 $\mathrm{mm} \rightarrow \mathrm{SCL}=2,0442 \mathrm{~m} \rightarrow \mathrm{t}_{\mathrm{c}}=0,6133 \mathrm{~s}$

$5^{\mathrm{a}}$ operação: chanfrar diâm $17,95 \mathrm{~mm} \rightarrow \mathrm{SCL}=0,3876 \mathrm{~m} \rightarrow \mathrm{t}_{\mathrm{c}}=0,1163 \mathrm{~s}$

6a operação: facear até diâm 10,50 $\mathrm{mm} \rightarrow \mathrm{SCL}=0,6953 \mathrm{~m} \rightarrow \mathrm{t}_{\mathrm{c}}=0,2086 \mathrm{~s}$

Tempo de corte para uma peça: $1,9522 \mathrm{~s}$

Estado da aresta "2": pequeno desgaste

Desgaste: inferior a $0,1 \mathrm{~mm}$

Duração do Ensaio II aresta " 2 ": 249 peças ou 8,10 minutos

Estado da aresta "3": bom

Desgaste: inferior a $0,1 \mathrm{~mm}$

Duração do Ensaio II aresta "3": 223 peças ou 7,25 minutos

Custo do inserto com 6 arestas: $\mathrm{R} \$ 32,81$

Custo por peça usinada no Ensaio II aresta " 2 " : R \$ 0,0220

Custo por peça usinada no Ensaio II aresta “3” : R \$ 0,0245

Segundo o catálogo do fabricante:

Expectativa de vida mínima: 15 min ou 461 peças $\rightarrow$ custo por peça: R\$ 0,0119

Expectativa de vida máxima:40 min ou 1229 peças $\rightarrow$ custo por peçaR $\$ 0,0044$ 


\section{Ensaio Fase I}

Inserto para Corte com largura de 2,00 mm "Fabricante B"

Velocidade de corte: $132 \mathrm{~m} / \mathrm{min}=2,20 \mathrm{~m} / \mathrm{s}$

$1^{\text {a }}$ operação: cortar do diâm 30,00 a $24 \mathrm{~mm} \rightarrow \mathrm{SCL}=2,1206 \mathrm{~m} \rightarrow \mathrm{t}_{\mathrm{c}}=0,9639 \mathrm{~s}$

$2^{\mathrm{a}}$ operação: cortar do diâm 30,00 a 25,3 $\mathrm{mm} \rightarrow \mathrm{SCL}=0,9113 \mathrm{~m} \rightarrow \mathrm{t}_{\mathrm{c}}=0,4142 \mathrm{~s}$ $3^{a}$ operação: chanfrar diâmetro $30,00 \mathrm{~mm} \rightarrow \mathrm{SCL}=0,6553 \mathrm{~m} \rightarrow \mathrm{t}_{\mathrm{c}}=0,2979 \mathrm{~s}$

$4^{\mathrm{a}}$ operação: cortar do diâm 29,00 a $25,00 \mathrm{~mm} \rightarrow \mathrm{SCL}=0,9425 \mathrm{~m} \rightarrow \mathrm{t}_{\mathrm{c}}=0,4284 \mathrm{~s}$

$5^{\mathrm{a}}$ operação: cilindrar diâmetro $25,00 \mathrm{~mm} \rightarrow \mathrm{SCL}=1,4137 \mathrm{~m} \rightarrow \mathrm{t}_{\mathrm{c}}=0,6426 \mathrm{~s}$

6 operação: chanfrar diâm $25,00 \mathrm{~mm} \rightarrow \mathrm{SCL}=0,5443 \mathrm{~m} \rightarrow \mathrm{t}_{\mathrm{c}}=0,2177 \mathrm{~s}$

$7^{\mathrm{a}}$ operação: cortar do diâm 24,00 a 7,00 $\mathrm{mm} \rightarrow \mathrm{SCL}=8,2781 \mathrm{~m} \rightarrow \mathrm{t}_{\mathrm{c}}=3,3112 \mathrm{~s}$

Tempo de corte para uma peça: $6,2759 \mathrm{~s}$

Estado da aresta: bom

Desgaste: inferior a $0,1 \mathrm{~mm}$ (flanco)

Duração do Ensaio I: 291 peças ou 30,4381 minutos

Custo do inserto com 2 arestas: R\$54,00

Custo por peça usinada: $\mathrm{R} \$ 0,0928$

Segundo o catálogo do fabricante:

Expectativa de vida mín: 15 min ou 143 peças $\rightarrow$ custo por peça: $\mathrm{R} \$ 0,1888$

Expectativa de vida máx:40 min ou 382 peças $\rightarrow$ custo por peça: $\mathrm{R} \$ 0,0707$

\section{Ensaio Fase II}

Inserto para Corte com largura de 2,00 mm "Fabricante A"

Velocidade de corte: $200 \mathrm{~m} / \mathrm{min}=3,33 \mathrm{~m} / \mathrm{s}$

$1^{a}$ operação: cortar do diâm 30,00 a $24 \mathrm{~mm} \rightarrow \mathrm{SCL}=2,1179 \mathrm{~m} \rightarrow \mathrm{t}_{\mathrm{c}}=0,6360 \mathrm{~s}$

$2^{\mathrm{a}}$ operação: cortar do diâm 30,00 a 25,5 $\mathrm{mm} \rightarrow \mathrm{SCL}=0,8757 \mathrm{~m} \rightarrow \mathrm{t}_{\mathrm{c}}=0,2627 \mathrm{~s}$

$3^{\mathrm{a}}$ operação: chanfrar diâmetro $30,00 \mathrm{~mm} \rightarrow \mathrm{SCL}=0,6553 \mathrm{~m} \rightarrow \mathrm{t}_{\mathrm{c}}=0,1966 \mathrm{~s}$

$4^{\mathrm{a}}$ operação:cortar do diâm 29,00 a 25,00 $\mathrm{mm} \rightarrow \mathrm{SCL}=0,9425 \mathrm{~m} \rightarrow \mathrm{t}_{\mathrm{c}}=0,2827 \mathrm{~s}$

$5^{\mathrm{a}}$ operação: cilindrar diâmetro $25,00 \mathrm{~mm} \rightarrow \mathrm{SCL}=1,4137 \mathrm{~m} \rightarrow \mathrm{t}_{\mathrm{c}}=0,4241 \mathrm{~s}$

$6^{\mathrm{a}}$ operação: chanfrar diâmetro $25,00 \mathrm{~mm} \rightarrow \mathrm{SCL}=0,5443 \mathrm{~m} \rightarrow \mathrm{t}_{\mathrm{c}}=0,1814 \mathrm{~s}$

$7^{\mathrm{a}}$ operação:cortar do diâm 24,00 a 7,00 $\mathrm{mm} \rightarrow \mathrm{SCL}=8,2781 \mathrm{~m} \rightarrow \mathrm{t}_{\mathrm{c}}=2,7594 \mathrm{~s}$

Tempo de corte para uma peça: $4,7429 \mathrm{~s}$ 
Estado da aresta: fratura catastrófica

Duração do Ensaio II: 472 peças ou 37,3108 minutos

Custo do inserto com 2 arestas: $\mathrm{R} \$ 68,70$

Custo por peça usinada: $\mathrm{R} \$ 0,073$

Segundo o catálogo do fabricante:

Expectativa de vida mínima: 15 min ou 190 peças $\rightarrow$ custo por peça: $\mathrm{R} \$ 0,1808$

Expectativa de vida máxima: 506 min ou 382 peças $\rightarrow$ custo por peça: $\mathrm{R} \$ 0,0679$ 


\section{APÊNDICE E - CUSTOS DO PROCESSO}

Custo da Hora Máquina: R\$14,50

Produção 112 peças / $\mathrm{h} \rightarrow$ custo por peça: $\mathrm{R} \$ 0,1295$

Custo da Matéria Prima: aço ABNT 1020 R\$ 3,70 / Kg

Dimensões: diâmetro $30 \mathrm{~mm} \times 13,8 \mathrm{~mm} \rightarrow$ volume $=9,90 \mathrm{~cm}^{3} \rightarrow$ massa $=77,2 \mathrm{~g}$

Custo do aço por peça: $\mathrm{R} \$ 0,2856$

Espessura de corte $1 \mathrm{~mm} \rightarrow$ volume $=0,707 \mathrm{~cm}^{3} \rightarrow$ massa $=5,51 \mathrm{~g}$

Custo do aço por $1 \mathrm{~mm}$ de largura de corte: $\mathrm{R} \$ 0,0204$

\section{Custo das Ferramentas do Ensaio}

Inserto Triangular de Aresta Aguda para Facear "Fabricante A".

Duração do Ensaio I: 307 peças ou 9,07 minutos

Custo do inserto com 6 arestas: $\mathrm{R} \$ 32,81$

Custo por peça usinada: $\mathrm{R} \$ 0,0178$

Duração do Ensaio II aresta “2”: 249 peças ou 8,10 minutos

Duração do Ensaio II aresta “3”: 223 peças ou 7,25 minutos

Custo do inserto com 6 arestas: $\mathrm{R} \$ 32,81$

Custo por peça usinada no Ensaio II aresta “2” : R\$ 0,0220

Custo por peça usinada no Ensaio II aresta “3” : R \$ 0,0245

Inserto para Corte com largura de 2,00 mm "Fabricante B"

Duração do Ensaio I: 291 peças ou 30,4381 minutos

Custo do inserto com 2 arestas: $\mathrm{R} \$ 54,00$

Custo por peça usinada: $\mathrm{R} \$ 0,0928$

Inserto para Corte com largura de 2,00 mm "Fabricante A"

Duração do Ensaio II: 472 peças ou 37,3108 minutos

Custo do inserto com 2 arestas: $\mathrm{R} \$ 68,70$

Custo por peça usinada: $\mathrm{R} \$ 0,0727$ 


\section{Custos relativos ao fluido de corte}

Custo fluido de corte Bio G 517: R\$ 12,50/ $\ell$

Custo reservatório de $200 \ell$ ( concentração $5 \%$ ) $\rightarrow 10 \ell \rightarrow \mathrm{R} \$ 125,00$

Custo de reposição $10 \%$ ao mês $\rightarrow 1 \ell \rightarrow \mathrm{R} \$ 12,50 /$ mês

Custos de tratamento

Custo dos produtos empregados no "tratamento 1" para $200 \ell: \mathrm{R} \$ 2,30$

Ácido para a quebra da solução $5 \mathrm{~m} \ell / \ell \rightarrow 200 \ell \rightarrow \mathrm{R} \$ 1,10$

Hidróxido para a precipitação dos metais $3 \mathrm{~m} \ell / \ell \rightarrow 200 \ell \rightarrow \mathrm{R} \$ 1,10$

Polímero com função aglutinante $0,02 \mathrm{~g} / \ell \rightarrow 200 \ell \rightarrow \mathrm{R} \$ 0,10$

Os custos de instalações, equipamento e mão de obra não foram estimados por não existirem em condições comerciais.

Custos de disposição (dados fornecidos pelo LRQ-PCASC-USP)

Custo para a disposição em aterro industrial: $\mathrm{R} \$ 600,00 / 1.000 \mathrm{Kg}^{*} \rightarrow 2 \mathrm{Kg}=\mathrm{R} \$ 1,20$

* quantidade mínima

Custo de transporte: $\mathrm{R} \$ 1.500,00$ (até $15.000 \mathrm{Kg}$ )

Custo para a pior condição $1.000 \mathrm{Kg} \quad \rightarrow 2 \mathrm{Kg}=\mathrm{R} \$ 3,00$

Custo para a melhor condição $15.000 \mathrm{Kg} \rightarrow 2 \mathrm{Kg}=\mathrm{R} \$ 0,20$

Custo da documentação para o transporte (CADRI): $\mathrm{R} \$ 1.500,00$

Custo para a pior condição $1.000 \mathrm{Kg} \rightarrow 2 \mathrm{Kg}=\mathrm{R} \$ 3,00$

Custo para a melhor condição $15.000 \mathrm{Kg} \rightarrow 2 \mathrm{Kg}=\mathrm{R} \$ 0,20$

Horas trabalhadas:

1 mês $\rightarrow 440$ horas

6 meses $\rightarrow 2.600$ horas

1 ano $\rightarrow 5.000$ horas

2 anos $\rightarrow 10.000$ horas

Tempo efetivo de corte: $0,6 \times$ horas trabalhadas

Produção estimada 100 peças/hora

O custo de disposição para $2 \mathrm{Kg}$ de resíduo será adotado: $\mathrm{R} \$ 10,00$

O custo de tratamento para $200 \ell$ será adotado: $\mathrm{R} \$ 10,00$

Cálculo do custo do fluido de corte por peça usinada: $\mathrm{C}$

$\mathrm{C}=\left(\mathrm{C}_{\text {reservatório }}+\mathrm{C}_{\text {reposição }}+\mathrm{C}_{\text {disposição }}+\mathrm{C}_{\text {tratamento }}\right) / \mathrm{n}$ ॰ total de peças

Supondo a pior condição 1 mês de trabalho

$\mathrm{R} \$ 125,00+(\mathrm{R} \$ 12,50 \times 1)+\mathrm{R} \$ 10,00+\mathrm{R} \$ 10,00=\mathrm{R} \$ 157,50$

$\mathrm{C}=\mathrm{R} \$ 157,50 /(440 \mathrm{~h} \times 0,6 \times 100$ peças $/ \mathrm{h})=\mathrm{R} \$ 0,006$

Supondo a melhor condição 2 anos de trabalho

$\mathrm{R} \$ 125,00+(\mathrm{R} \$ 12,50 \times 24)+\mathrm{R} \$ 10,00+\mathrm{R} \$ 10,00=\mathrm{R} \$ 157,50$

$\mathrm{C}=\mathrm{R} \$ 157,50 /(10.000 \mathrm{~h} \times 0,6 \times 100$ peças $/ \mathrm{h})=\mathrm{R} \$ 0,0007$ 


\section{APÊNDICE F - ESTIMATIVAS DE ECONOMIA}

\section{I-Economia de aço com a substituição da largura de corte da peça.}

Peça: Bucha Espaçadora

Material: aço ABNT 1020

Custo: $\mathrm{R} \$ 3,70 / \mathrm{Kg}$

Dimensões: diâmetro $30 \mathrm{~mm} \times 13,8 \mathrm{~mm} \rightarrow$ volume $=9,90 \mathrm{~cm}^{3} \rightarrow$ massa $=77,2 \mathrm{~g}$

Espessura de corte $1 \mathrm{~mm} \rightarrow$ volume $=0,707 \mathrm{~cm}^{3} \rightarrow$ massa $=5,51 \mathrm{~g}$

Economia de aço em um lote de 100.000 peças $\rightarrow 551 \mathrm{Kg}$

Economia de R \$2.040,00

Peça: Capa Maior

Diâmetro: $20 \mathrm{~mm}$

Espessura de corte $1 \mathrm{~mm} \rightarrow$ volume $=0,314 \mathrm{~cm}^{3} \rightarrow$ massa $=2,45 \mathrm{~g}$

Economia de aço em um lote de 6.000 peças $\rightarrow 14,7 \mathrm{Kg}$

Economia de $\mathrm{R} \$ 54,40$

Produção em um ano: 60.000 peças $\rightarrow$ economia de $147 \mathrm{Kg}$

II-Projeção da economia de aço na empresa com a redução de $1 \mathrm{~mm}$ na largura de corte "la".

Diâmetro médio das peças: $18 \mathrm{~mm} \rightarrow$ volume de corte $=0,254 \mathrm{~cm}^{3}$

Produção em um mês: 60.000 peças $\rightarrow$ economia de $119 \mathrm{Kg}$

Estima-se em um ano $\rightarrow 1.400 \mathrm{Kg}$ 